\title{
Alysson Zanatta
}

Expressão proteica do gene HOXA10 e dos receptores de estrogênio e progesterona no epitélio, estroma e tecido muscular liso perilesional de endometriose do reto-sigmoide

Tese apresentada à Faculdade de Medicina da Universidade de São Paulo para obtenção do título de Doutor em Ciências

Programa de Obstetrícia e Ginecologia Orientador: Prof. Dr. Paulo Cesar Serafini

São Paulo

2013 
Dados Internacionais de Catalogação na Publicação (CIP)

Preparada pela Biblioteca da

Faculdade de Medicina da Universidade de São Paulo

Creprodução autorizada pelo autor

\section{Zanatta, Alysson}

Expressão proteica do gene HOXA10 e dos receptores de estrogênio e progesterona no epitélio, estroma e tecido muscular liso perilesional de endometriose do reto-sigmoide / Alysson Zanatta. -- São Paulo, 2013.

Tese(doutorado)--Faculdade de Medicina da Universidade de São Paulo.

Programa de Obstetrícia e Ginecologia.

Orientador: Paulo Cesar Serafini.

Descritores: 1.Genes homeobox 2.Receptor alfa de estrogênio 3.Receptor beta de estrogênio 4.Endometriose/metabolismo 5.Endometriose/etiologia 6.Receptores de progesterona 7.Estradiol 8.Progesterona 9.Proteínas de homeodomínio/metabolismo 10.HOXA 10 proteína humana 11.Doenças do colo sigmoide

USP/FM/DBD-182/13 
"Lembrar-se de que você irá morrer é a melhor maneira que eu conheço de evitar a armadilha de imaginar que você tem algo a perder.

Você já está nu.

Não há nenhum motivo para não seguir o seu coração"

Steve Jobs

Paraninfo em Stanford, 2005 


\section{Dedicatória}

Aos meus pais, Rosemaria e Antonio Carlos, meus maiores exemplos de amor e de vida. Minha identidade, minha base, meus ídolos.

À minha amada esposa, Letícia Paz, que me tornou uma pessoa melhor. Obrigado pelo carinho, compreensão, motivação e apoio em tudo que faço. Obrigado por ser minha referência e meu equilíbrio. Obrigado pela paz. Obrigado pelo seu amor.

À minha querida família: meus queridos irmãos, Alyne e Alan; minha querida cunhada, Regiane; meus lindos sobrinhos, Júlia, Guilherme e Murilo; meus padrinhos, Dionísio e Teresinha; minha família norte-americana, Edward Rodrigues e Martin Flores. Obrigado pelos estímulos, pelos incentivos, por fazerem parte de mim.

À minha mais nova família, meus queridos sogros, Hélio e Margaret Mello, meus grandes cunhados, Bruno e Fernando. Sou muito feliz e honrado por terem me acolhido nesta linda família, e da qual muito me orgulho. 


\section{Agradecimentos}

Ao Prof. Dr. Paulo Cesar Serafini, o maior incentivador não apenas desta tese, mas de toda a minha curiosidade pelo método científico; pelas condições integrais e irrestritas para a pesquisa, pela liberdade e incentivo ao pensamento; pelos exemplos de trabalho árduo, de dedicação às pacientes, e de paixão pela Medicina.

Ao Dr. André Monteiro da Rocha, um dos maiores responsáveis por esta tese; pelos esforços, interesse e grande trabalho que tornaram possível a sua realização; pelas valiosas ideias e por solucionar minhas dúvidas.

Ao Dr. Ricardo Mendes Alves Pereira, pela realização de todas as cirurgias das pacientes avaliadas nesta tese; por todos os ensinamentos e total incentivo durante toda a minha vida profissional; pela amizade, pelo apoio naqueles momentos difíceis; pelos exemplos únicos de integridade, maestria, competência e dedicação à profissão e às pacientes. São esses exemplos os maiores responsáveis pelo meu interesse, primeiro pela Ginecologia e Obstetrícia e, posteriormente, pela Cirurgia Ginecológica.

À Huntington Medicina Reprodutiva e a todos os seus colaboradores, representados pelo Prof. Dr. Paulo Cesar Serafini e pelo Prof. Dr. Eduardo Leme Alves da Motta, por terem me recebido e proporcionado todas as condições para a realização deste estudo; pela grandiosa oportunidade de aprender e colaborar com colegas em um centro de excelência máxima em Medicina Reprodutiva.

Ao Prof. Dr. Edmund Chada Baracat, pelas supervisão científica do projeto; pela oportunidade ímpar que me proporcionou ao me acolher na Universidade de São Paulo, possibilitando todo o aprendizado e experiência de vida que pude adquirir ao realizar este estudo. 
À Profa. Dra ${ }^{\text {a }}$ Filomena Marino Carvalho, pela grande contribuição na interpretação patológica das lâminas deste estudo, e pelo esclarecimento de minhas dúvidas.

Ao Prof. Dr. José Luiz Guerra, pela seleção das áreas de amostragem nos espécimes cirúrgicos, o ponto de partida deste estudo.

Ao Prof. Dr. Bruno Cogliati, pelas orientações e ensinamentos durante a segunda fase deste estudo; por concordar em ajudar um então desconhecido.

À $\mathrm{Dr}^{\mathrm{a}}$. Tereza Cristina da Silva, pelo enorme esforço no preparo das lâminas durante a segunda fase do estudo, e por me explicar seus aspectos técnicos.

Ao Prof. Dr. Hugh Taylor, pelas orientações nas interpretações clínicas dos resultados deste estudo, e por esclarecer minhas dúvidas.

Ao Dr. Bernardo Almeida, pela preciosa contribuição na interpretação patológica das lâminas deste estudo.

Ao Dr. Rogério Ruscitto do Prado, pela análise estatística dos resultados deste estudo, pela paciência em esclarecer minhas dúvidas.

Ao Prof. Dr. Carlos Bacchi, pelo preparo e construção das lâminas deste estudo.

Ao Sr. Jamil Fonseca de Oliveira, que me ensinou muito sobre Cirurgia Ginecológica, ainda que não seja médico.

Aos amigos do Núcleo de Endoscopia Ginecológica e Endometriose do Hospital Pérola Byington, representados pelo Dr. Luciano Gibran, pelos alegres e produtivos momentos de aprendizado mútuo; pela compreensão para que eu pudesse me dedicar a este estudo.

Às queridas pacientes que concordaram em participar deste estudo. Suas contribuições foram ímpares. Ter participado de suas vidas é motivo de grande orgulho para mim. 


\section{Sumário}

Lista de Abreviaturas

Lista de Figuras

Lista de Tabelas

Lista de Quadros

Lista de Gráficos

Resumo

Abstract

1. INTRODUÇÃO.................................................................. 1

1.1 Genes homeóticos, genes homeobox, e gene homeobox A10.............. 3

1.2 Receptores de estrogênio e endometriose....................................... 8

1.3 Receptores de progesterona e endometriose ................................... 9

1.4 O elo de ligação entre HOXA10, estrogênios, progesterona e endometriose

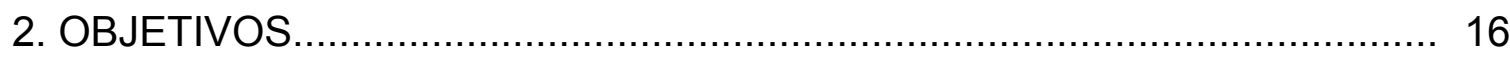

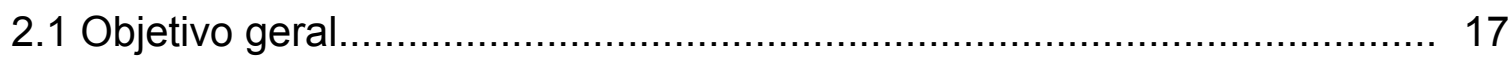

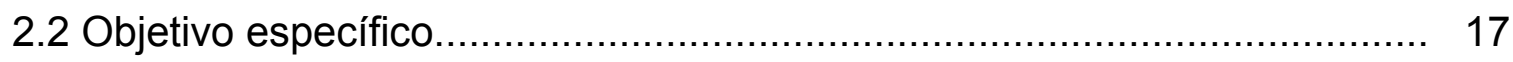

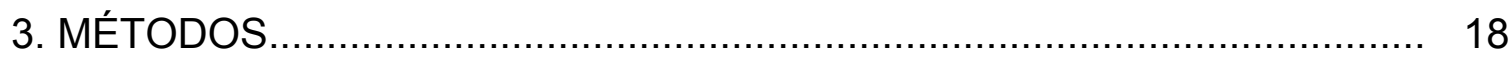

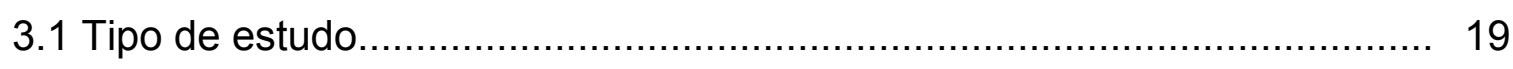

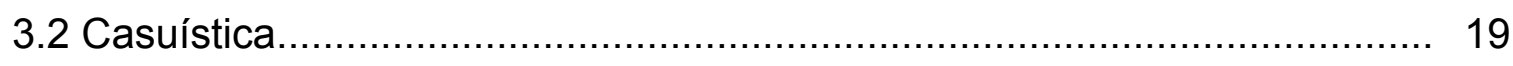

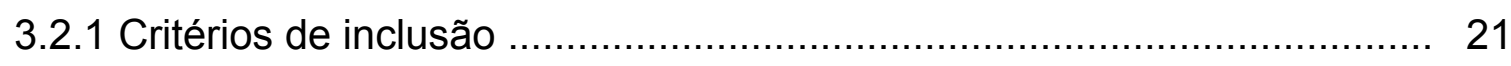

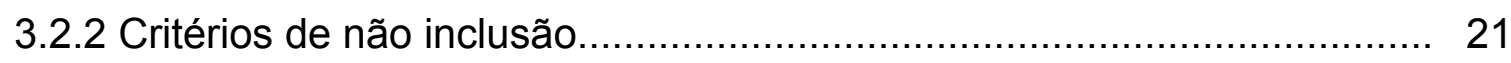

3.3 Condições do estudo........................................................... 21

3.4 Confecção dos blocos de microarranjos de tecidos.............................. 23

3.5 Reações de imunoistoquímica ................................................... 26

3.6 Interpretação imunoistoquímica por microscopia ótica ......................... 27

3.7 Interpretação imunoistoquímica por análise morfométrica...................... 29

3.8 Análise estatística................................................................... 31

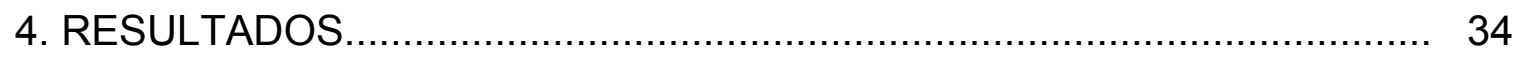

4.1 Resultados das expressões imunoistoquímicas das proteínas HOXA10, ER-a, PR-AB e PR-B segundo análise por microscopia ótica.................. 35

4.2 Resultados das expressões imunoistoquímicas das proteínas HOXA10, ER-ß, PR-AB e PR-B segundo análise morfométrica 
5. DISCUSSÃO

5.1 Considerações específicas........................................................... 49

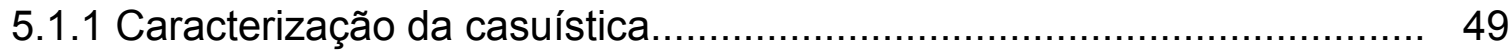

5.1.2 Considerações sobre o fator de transcrição HOXA10 ............................ 52

5.1.3 Considerações sobre os receptores de estrogênio................................ 55

5.1.4 Considerações sobre os receptores de progesterona............................ 57

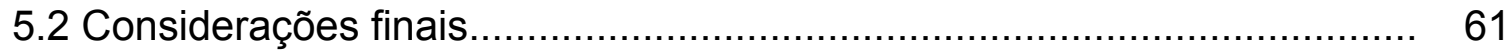

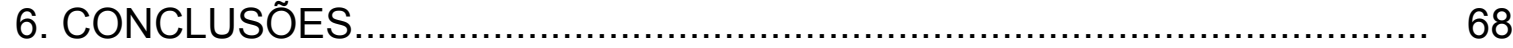

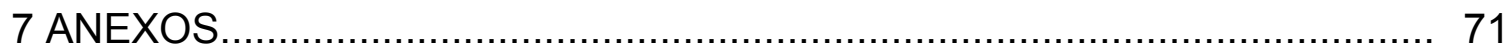

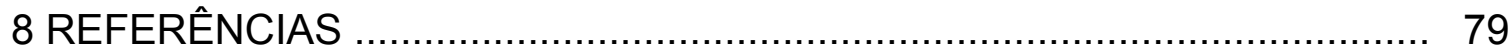

APÊNDICES 


\section{Lista de Abreviaturas}

\begin{tabular}{|c|c|}
\hline AM & Análise morfométrica \\
\hline AMS & Área de marcação do spot \\
\hline ATS & Área total do spot \\
\hline ASRM & $\begin{array}{l}\text { Sociedade Americana para Medicina Reprodutiva (American } \\
\text { Society for Reproductive Medicine) }\end{array}$ \\
\hline BPA & Bisfenol-A \\
\hline CAPPesq & Comissão de ética para análise de projetos de pesquisa \\
\hline DAB & 3,3 ' diaminobenzidina \\
\hline DES & Dietilestilbestrol \\
\hline DNA & Ácido desoxirribonucleico \\
\hline EOV & Endometriose ovariana \\
\hline EPF & Endometriose profunda \\
\hline EPT & Endometriose peritoneal \\
\hline ER & Receptor de estrogênio \\
\hline ER- $\alpha$ & Receptor de estrogênio alfa \\
\hline ER-ß & Receptor de estrogênio beta \\
\hline ERS & Endometriose de reto-sigmoide \\
\hline HOXA9 & Gene homeobox A9 \\
\hline HOXA10 & Gene homeobox A10 \\
\hline HOXA11 & Gene homeobox A11 \\
\hline HOXA13 & Gene homeobox A13 \\
\hline LES & Lesão de endometriose, porção glandular e estromal \\
\hline MO & Microscopia ótica \\
\hline PBS & Salina tamponada com fosfato (phosphate-buffered saline) \\
\hline PR-A & Receptor de progesterona A \\
\hline PR-AB & Receptor de progesterona $A B$ \\
\hline PR-B & Receptor de progesterona B \\
\hline RNAm & Ácido ribonucleico mensageiro \\
\hline SPSS & Statistical Package for Social Science \\
\hline
\end{tabular}


TMA Microarranjo de tecidos (tissue microarray)

TMLP Tecido muscular liso perilesional 


\section{Lista de Figuras}

Figura 1. Os genes homeobox conferem identidade tecidual ao ducto de Müller indiferenciado durante o período embrionário. O gene homeobox A10 (HOXA10) confere a identidade de útero

Figura 2. Endometriose de reto-sigmoide. Destaque para o componente fibromuscular da lesão

Figura 3. Escolha das regiões para realização da amostragem no bloco doador $(A)$ e identificação na comparação com o bloco de parafina (B)

Figura 4. Realização das amostragens de blocos doadores, receptores e montagem dos blocos de microarranjos de tecidos

Figura 5. Amostras de 18 pacientes resultaram em 4 blocos de TMA, cada um com 285 spots

Figura 6. O software Pannoramic Viewer foi utilizado para a análise morfométrica das imagens digitalizadas das lâminas de TMA

Figura 7. Expressão da proteína HOXA10 em lesão de endometriose de reto-sigmoide. A expressão é restrita aos núcleos de células do estroma endometrial

Figura 8. Expressão das proteínas ER- $\alpha, E R-\beta, P R-A B$ e PR-B em lesão de endometriose de reto-sigmoide. Todas as proteínas são expressas nas glândulas e estroma endometriais, e restritas aos núcleos das células

Figura 9. Expressão da proteína HOXA10 em tecido muscular liso perilesional de endometriose de reto-sigmoide. A expressão é positiva fraca e mais evidente nos núcleos de células do estroma endometrial entremeadas no tecido muscular liso

Figura 10. Expressão das proteínas ER- $\alpha, E R-\beta, P R-A B$ e PR-B em tecido perilesional de endometriose de reto-sigmoide. Há escassez de glândulas e estroma e predominância de tecido muscular liso. As proteínas ER- $\alpha$ e ER-ß são expressas no estroma e tecido muscular liso, enquanto as proteínas PR-AB e PR-B têm expressões positivas fracas e restritas às células estromais entremeadas no tecido muscular liso

Figura 11. Embriogênese do trato genital feminino e papel proposto do gene HOXA10 na etiologia da endometriose. Perspectivas (a) coronal e (b) paramediana do embrião humano feminino com seis semanas de gestação. Pregas longitudinais de células mesenquimais invaginam-se a partir das paredes abdominais laterais para formarem cordões que crescem caudalmente e se fundem na linha média (os ductos paramesonéfricos, destacados em azul), como indicado por setas pequenas. O gene HOXA10 irá conferir a identidade à porção do ducto destinada a ser o útero, incluindo o endométrio. (c) Possivelmente, células mesenquimais sob a influência do gene HOXA10 possam ser destinadas a se tornarem células endometriais em localizações ectópicas, incluindo o tórus uterino (TU), ligamentos útero-sacros (USL), paredes pélvicas laterais $(P S)$, reto-sigmoide $(R)$, entre outros. Esses locais corresponderiam às localizações mais comuns das lesões de endometriose (marcas negras) observadas na mulher adulta ( $d$, e). UT=útero; US=seio urogenital e bexiga em desenvolvimento; $\mathrm{BL}=$ bexiga 


\section{Lista de Tabelas}

Tabela 1 Características clínico-epidemiológicas de pacientes inférteis submetidas à ressecção laparoscópica de endometriose incluindo retossigmoidectomia - jun. 2003 a jul. 2007

Tabela 2 Comparações das expressões das proteínas HOXA10, ER- $\alpha$, PR-AB e PR-B em endometriose de reto-sigmoide analisadas por microscopia ótica, segundo a interação entre fase do ciclo menstrual e local de expressão, e individualizadas por fase e local

Tabela 3 Comparações múltiplas das expressões imunoistoquímicas das proteínas HOXA10 estromal, ER- $\alpha$ estromal, PR-AB glandular, PR-B glandular e PR-B estromal analisadas por microscopia ótica, segundo o local de expressão e a fase do ciclo menstrual

Tabela 4 Correlações entre as expressões imunoistoquímicas das proteínas HOXA10, ER- $\alpha$, PR-AB e PR-B analisadas por microscopia ótica em endometriose de reto-sigmoide

Tabela 5 Comparações das expressões imunoistoquímicas das proteínas HOXA10, ER- $\beta$, PR-AB e PR-B em endometriose de reto-sigmoide avaliadas por análise morfométrica, segundo a interação entre fase do ciclo menstrual e local de expressão, e individualizadas por fase e local

Tabela 6 Comparação múltipla da expressão imunoistoquímica da proteína PR-B avaliada por análise morfométrica, segundo a expressão na lesão e no tecido perilesional de endometriose de reto-sigmoide

Tabela 7 Correlações entre as expressões imunoistoquímicas das proteínas HOXA10, ER- $B, P R-A B$ e PR-B segundo análise morfométrica em endometriose de reto-sigmoide 


\section{Lista de Quadros}

Quadro 1 Tipo, procedência e diluição dos anticorpos monoclonais utilizados nas reações de imunoistoquímica

Quadro 2 Critérios modificados de Allred para quantificação de marcação imunoistoquímica 


\section{Lista de Gráficos}

Gráfico 1. Valores médios e respectivos erros padrão das expressões imunoistoquímicas das proteínas HOXA10, ER- $\alpha$, PR-AB e PR-B em lesão e tecido perilesional de endometriose de reto-sigmoide segundo análise por microscopia ótica, durante a fase proliferativa do ciclo menstrual

Gráfico 2. Valores médios e respectivos erros padrão das expressões imunoistoquímicas das proteínas HOXA10, ER- $\alpha$, PR-AB e PR-B em lesão e tecido perilesional de endometriose de reto-sigmoide segundo análise por microscopia ótica, durante a fase secretora do ciclo menstrual

Gráfico 3. Valores médios e respectivos erros padrão das expressões imunoistoquímicas das proteínas HOXA10, ER-B, PR-AB e PR-B em lesão e tecido perilesional de endometriose de reto-sigmoide segundo análise morfométrica, durante a fase proliferativa do ciclo menstrual

Gráfico 4. Valores médios e respectivos erros padrão das expressões imunoistoquímicas das proteínas HOXA10, ER-ß, PR-AB e PR-B em lesão e tecido perilesional de endometriose de reto-sigmoide segundo análise morfométrica, durante a fase secretora do ciclo menstrual 


\section{Resumo}

Zanatta A. Expressão proteica do gene HOXA10 e dos receptores de estrogênio e progesterona no epitélio, estroma e tecido muscular liso perilesional de endometriose do reto-sigmoide [tese]. São Paulo: Faculdade de Medicina, Universidade de São Paulo; 2013.

INTRODUÇÃO: Apesar de a endometriose profunda (EPF) ser a forma da doença de maior repercussão clínica, os estudos sobre a doença costumam ser baseados em lesões de endometriose ovariana (EOV) e peritoneal (EPT). A patogênese da EPF ainda é objeto de amplo debate, pois há poucos estudos feitos exclusivamente com lesões de EPF. O fator de transcrição codificado pelo gene homeobox A10 (HOXA10) regula a conferência de identidade tecidual de útero ao ducto paramesonéfrico indiferenciado durante o período embrionário. $O$ gene mantém um padrão de expressão temporal e espacial bem definido e, durante a fase adulta, continua expresso no miométrio e endométrio. Sugere-se que HOXA10 esteja implicado na patogênese da endometriose, pois é expresso em EOV, EPT, endometriose pulmonar e endometriose retovaginal, um tipo de EPF. Possivelmente, o gene HOXA10 seja necessário para conferir identidade de endometriose a um tecido indiferenciado. O estradiol e a progesterona ativam a transcrição do gene HOXA10 e regulam diretamente sua ação. Esses hormônios estão envolvidos na patogênese da EPF, e suas atividades podem ser inferidas pelo estudo da expressão tecidual de seus receptores. A endometriose de reto-sigmoide (ERS) é um modelo representativo para o estudo da EPF. Neste estudo, avaliamos a expressão proteica do fator de transcrição HOXA10, das isoformas $\alpha$ (ER- $\alpha)$ e $\beta$ $(E R-\beta)$ dos receptores de estrogênio, e do receptor de progesterona $A B$ (PR-AB) e sua isoforma $B$ (PR-B) na lesão (LES) e no tecido muscular liso perilesional (TMLP) de ERS de pacientes inférteis, durante as fases proliferativa e secretora do ciclo menstrual. MÉTODOS: amostras de LES e TMLP de ERS de 18 pacientes ( 9 operadas em cada fase do ciclo menstrual) foram agrupadas em blocos de microarranjos de tecidos (tissue microarray). As amostras foram coradas com anticorpos específicos para análise imunoistoquímica de cada uma das proteínas. Foram então avaliadas por microscopia ótica (MO) e pela análise das imagens digitalizadas das lâminas com por um software específico, a análise morfométrica (AM). RESULTADOS: HOXA10 foi expresso no estroma de LES de ERS durante a fase secretora, de acordo com a MO. ER- $\alpha$ e ER- $\beta$ foram expressos em glândulas $e$ estroma de LES e TMLP de ERS durante ambas as fases do ciclo, de acordo com a MO e a AM. PR-AB e PR-B foram expressos em glândulas e estroma de LES de ERS durante ambas as fases do ciclo, de acordo com a MO. PR-B foi mais expresso durante a fase secretora, independentemente do local de expressão, segundo a AM. A expressão de HOXA10 correlacionou-se diretamente com PR-AB e PR-B na ERS, segundo a AM. Não houve correlação entre ER- $\alpha$ e ER- $\beta$ com HOXA10, PR-AB ou PR-B em nenhuma fase do ciclo ou local de expressão de ERS. CONCLUSÕES: HOXA10 é expresso em ERS, um local fora do seu eixo espacial de expressão. A presença de HOXA10 pode ser necessária para conferir a identidade "de novo" na EPF, incluindo ERS. A progesterona pode ativar o gene HOXA10 e regular esta ação, possivelmente mediada por PR-B. O estradiol exerce sua ação mitógena na ERS através ER- $\alpha$ e ER- $\beta$.

Palavras-chave: Gene HOXA10; Endometriose profunda; Endometriose de retosigmoide; Receptor de estrogênio $\alpha$; Receptor de estrogênio $\beta$; Receptor de progesterona; Receptor de progesterona B. 


\section{Abstract}

Zanatta A. HOXA10 as well as estrogen and progesterone receptor protein expression in the epithelium, stroma, and adjacent smooth muscle of rectosigmoid endometriosis. [thesis]. São Paulo: "Faculdade de Medicina, Universidade de São Paulo"; 2013.

INTRODUCTION: Although deep endometriosis (DE) is the major clinical form of endometriosis, studies regarding the disease are typically based on ovarian (OE) and peritoneal (PE) lesions. DE pathogenesis is still a matter of great discussion because there are few studies exclusively involving DE lesions. The transcription factor encoded by the homeobox gene A10 (HOXA10) regulates the identity imparted to the undifferentiated paramesonephric duct during embryogenesis. The gene is expressed in the myometrium and endometrium during adult life in a well-defined spatial and temporal mode. It has been suggested that HOXA10 plays a role in endometriosis pathogenesis because it is expressed in OE, PE, pulmonary endometriosis, and rectovaginal endometriosis, which is a clinical form of DE. Thus, HOXA10 may be necessary for "de novo" endometrial development from undifferentiated tissues. Both estradiol and progesterone activate HOXA10 transcription and directly regulate its action. These hormones are involved in DE pathogenesis, and therefore their activities could be assessed by studying the tissue expression of their receptors. Rectosigmoid endometriosis (RE) is a representative model for studying DE. In this study, we evaluated the protein expression of HOXA10, the estrogen receptor (ER) isoforms $\alpha(E R-\alpha)$ and $\beta$ (ER- $\beta$ ), the progesterone receptor $A B(P R)$, and the $P R$ isoform $B(P R-B)$ in lesions (LES) and adjacent smooth muscle (SM) of RE from infertile patients during the proliferative and secretory phases of the menstrual cycle. METHODS: LES and SM samples from RE patients were grouped in tissue microarray blocks. Each of the proteins was analyzed by immunohistochemistry using regular optical microscopy (OM) and a software-assisted analysis of digitalized images as well as morphometric analysis (MA). RESULTS: HOXA10 was expressed in the stroma of the LES during the secretory phase based on OM. ER- $\alpha$ and ER- $\beta$ were expressed in the glands and stroma of LES and SM during both phases based on OM and MA. PR and PR-B were expressed in the glands and stroma of LES during both phases; however, PR-B had higher expression during the secretory phase, independent of its expression in the LES or SM. HOXA10 expression was directly correlated with PR and PR-B expression in RE. In addition, there was no correlation between the expression of $E R-\alpha$ and ER- $\beta$ with HOXA10, PR, or PR-B during any phase of the menstrual cycle or site of expression. CONCLUSIONS: HOXA10 is expressed in RE outside of its spatial domain of expression, and may be necessary for "de novo" development of $\mathrm{DE}$, including RE. Progesterone might stimulate HOXA10 expression and regulate this action, which is most likely mediated by PR-B. Moreover, estradiol exerts its mitogenic effect in RE though ER- $\alpha$ and ER- $\beta$.

Keywords: HOXA gene; Deep endometriosis; Rectosigmoid endometriosis; Estrogen receptor- $\alpha$; Estrogen receptor- $\beta$; Progesterone receptor; Progesterone receptor-B. 
1 INTRODUÇÃO 
Endometriose pode ser definida como a presença de um tecido histologicamente similar ao endométrio (glândula ou estroma) em localização ectópica ${ }^{1}$. A doença é conhecida por sua associação à dor pélvica, infertilidade, e redução da qualidade de vida em mulheres ${ }^{2-4}$.

Há três formas distintas de endometriose pélvica: peritoneal (EPT), ovariana (EOV), e retovaginal ${ }^{5}$. A última também é conhecida como endometriose profunda ${ }^{6}(E P F)$, endometriose nodular, ou adenomiose do septo retovaginal ${ }^{7}$.

A EPF é a doença de maior significado clínico, presente em 5 a 10\% das mulheres ${ }^{2,8}$, e comumente responsabilizada pelos sintomas de dor e infertilidade associados à endometriose ${ }^{9-11}$. Essas lesões são encontradas no fórnice vaginal, ligamentos útero-sacros, bexiga, e em segmentos intestinais específicos: apêndice vermiforme, íleo terminal e reto-sigmoide.

Apesar de a EPF ser a doença de maior significado clínico, os inúmeros estudos sobre endometriose são tipicamente realizados com lesões de EPT e EOV ${ }^{12-18}$. Então, seus resultados são generalizados à endometriose como um todo, assumindo-se que representem exatamente a mesma doença. Certamente, esse é um dos motivos pelos quais a etiologia e a patogênese da EPF continuam sendo objeto de amplo debate.

A endometriose de reto-sigmoide (ERS) está presente em cerca de $25 \%$ das pacientes atendidas em centros de referência ${ }^{19,20}$. É um tipo de lesão que pode estar associado à infertilidade e sintomas de dor $^{20-23}$, cujo tratamento definitivo é a ressecção cirúrgica ${ }^{20,24-26}$. 
A ERS é um modelo típico de EPF. A lesão (LES) é composta por glândulas e/ou estroma endometriais escassos circundados por um extenso tecido muscular liso perilesional (TMLP) que contém fibrose, hiperplasia e metaplasia muscular lisa ${ }^{1}$. A preponderância de TMLP nessa lesão é responsável pelo seu volume e, possivelmente, por suas repercussões clínicas.

Os mecanismos pelos quais ocorrem a hiperplasia e a metaplasia musculares na EPF são desconhecidos. Uma das hipóteses é que células epiteliais e estromais das lesões poderiam induzir a ambos, por mecanismos parácrinos ainda a serem elucidados ${ }^{1,27,28}$.

Nesse sentido, Kitano et al. ${ }^{27}$ demonstraram a presença de receptores de estrogênio (ER) e progesterona (PR-AB) em metaplasia muscular lisa de lesões retovaginais de EPF. Da mesma forma, Nöel et al. ${ }^{28}$ avaliaram o TMLP de vários tipos de lesões de EPF (incluindo ERS), e também demonstraram a presença de ER e PR-AB no TMLP. Nesse estudo, as lesões de ERS foram as únicas lesões de EPF que não expressaram ER.

Os achados dessas pesquisas sugerem que os estrogênios e a progesterona atuem na metaplasia e hiperplasia muscular lisa observadas em EPF. Essa é uma hipótese que merece confirmação por estudos adicionais, já que o TMLP é o principal componente da EPF.

\subsection{Genes homeóticos, genes homeobox, e gene homeobox A10}

Genes homeóticos são genes reguladores do desenvolvimento embrionário de animais, fungos e plantas ${ }^{29}$. Apesar de os organismos 
multicelulares diferirem morfologicamente entre si, eles possuem mecanismos genéticos comuns para conferirem identidade celular e tecidual a tecidos embrionários indiferenciados, e, assim, determinarem a segmentação corporal anteroposterior.

Os genes homeobox (HOX genes) são genes homeóticos presentes nos vertebrados, sequenciados e clonados em 1984 a partir da mosca-dafruta Droshophila melanogaster ${ }^{30}$. Eles se caracterizam pela codificação de fatores de transcrição que contêm o homeodomínio (homeobox), uma sequência de 61 aminoácidos que reconhece e se liga às regiões promotoras do DNA de genes-alvo. Em humanos, há $39 \mathrm{HOX}$ genes que estão distribuídos nos loci A, B, C, e D, nos cromossomos 7, 17, 12 e 2, respectivamente ${ }^{31}$

Os HOX genes derivam de um único ancestral e são altamente conservados entre as espécies ${ }^{32}$. Por exemplo, os homeodomínios transcritos pelos HOX genes de humanos e pelos genes do complexo Antennapedia da Drosophila têm mais de $80 \%$ de similaridade entre si.

Os fatores de transcrição codificados pelos HOX genes podem agir isoladamente nas regiões promotoras dos genes, ou associados a outros fatores de transcrição na forma de complexos. Esses fatores podem então ativar ou inibir a transcrição de outros genes, que por sua vez ativarão ou inibirão os demais genes-alvo em um efeito cascata, culminando com uma ação final de morfogênese e/ou diferenciação celular.

Por exemplo, o desenvolvimento de antenas na Drosophila é um efeito mediado por esses genes. Nessa espécie, uma mutação experimental 
em um único gene homeótico pode causar o desenvolvimento de patas no lugar das antenas ${ }^{33}$. Essa é uma transformação homeótica.

Transformações homeóticas também são descritas em humanos. Porém, elas são menos evidentes devido à redundância dos vários HOX genes. Por exemplo, as malformações uterinas causadas pelo dietilestilbestrol (DES) são alterações fenotípicas causadas por alterações mediadas por HOX genes durante o período embrionário ${ }^{34,35}$.

Neste período, os HOX genes regulam a segmentação do trato reprodutivo feminino, além da segmentação corporal (Figura 1). A expressão espacial altamente organizada dos HOX genes A9 (HOXA9), A10 (HOXA10), A11 (HOXA11) e A13 (HOXA13) direcionam a morfogênese das trompas, corpo e colo uterinos, e porção superior da vagina, respectivamente ${ }^{36}$.

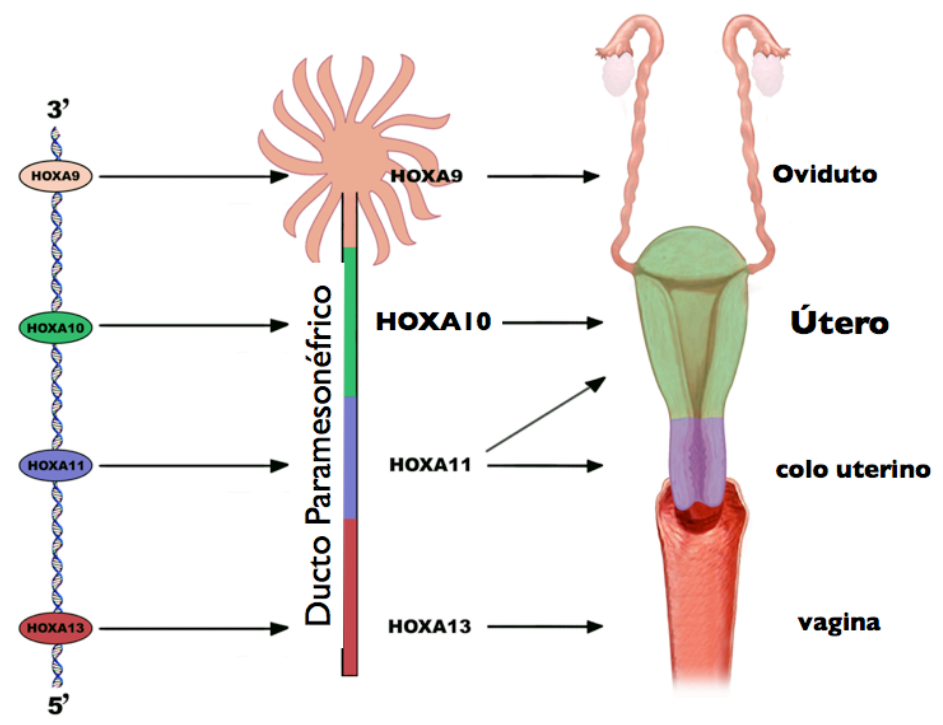

Figura 1. Os genes homeobox conferem identidade tecidual ao ducto de Müller indiferenciado durante o período embrionário. O gene homeobox A10 (HOXA10) confere a identidade de útero 
O gene HOXA10 é responsável por regular a atribuição da identidade de útero a uma porção do ducto paramesonéfrico indiferenciado ${ }^{36}$. Sua expressão permanece claramente delimitada entre a transição útero-tubárea e o istmo uterino, tanto no período embrionário como na fase adulta ${ }^{36}$.

Recentemente, mutações do gene HOXA10 foram descritas em mulheres com malformações Müllerianas, como útero didelfo e septado ${ }^{37,} 38$. Por outro lado, não há mutações conhecidas em mulheres com agenesia útero-vaginal (síndrome de Mayer-Rokitansky-Küster-Hauser) ${ }^{38}$. Esses achados podem reforçar a hipótese de que a função principal do gene HOXA10 seja a atribuição de identidade tecidual a tecidos indiferenciados (como o tecido mesodérmico do ducto paramesonéfrico), mais do que propriamente dar origem ao tecido Mülleriano.

$\mathrm{Na}$ fase adulta, os HOX genes regulam a diferenciação celular em tecidos de alta plasticidade, como o endométrio ${ }^{36}$ e a medula óssea ${ }^{39}$. A diferenciação celular funcional que ocorre em órgãos adultos selecionados recapitula processos de desenvolvimento embrionário, e essa diferenciação é implícita à fisiologia reprodutiva feminina. Como esperado, no trato genital feminino adulto, o gene HOXA10 é expresso no miométrio, glândulas e estroma endometriais, recapitulando o período embrionário ${ }^{36,40}$.

Em humanos, o período máximo da expressão de HOXA10 no endométrio coincide com a janela de implantação embrionária ${ }^{41}$. Em camundongos-fêmeas, mutações direcionadas causam esterilidade por fator uterino em homozigotos ${ }^{42}$, enquanto a transfecção intrauterina do gene 
aumenta a ninhada ${ }^{43}$. Esses achados ilustram a grande importância do gene HOXA10 no processo de implantação $0^{41,44,45}$.

Desta forma, a ação de HOXA10 sobre a diferenciação endometrial no adulto e o seu padrão de expressão espacial durante a organogênese do trato genital feminino estão de acordo com as funções primordiais dos genes homeóticos: segmentação corporal, diferenciação celular e atribuição de identidade tecidual.

Entretanto, apesar da sua localização espacial bem definida, HOXA10 é expresso em EOV, EPT, e até mesmo em endometriose pulmonar ${ }^{15}$. Esses são locais situados fora do eixo habitual de expressão do gene.

Lesões de EPF também expressam HOXA10. Van Langendonckt et al. ${ }^{46}$ estudaram lesões retovaginais de EPF, lesões de EPT e o endométrio de pacientes com endometriose. Os pesquisadores demonstraram a presença do gene e da proteína HOXA10 nessas lesões de EPF, em níveis superiores às lesões de EPT. Nesse estudo, lesões de ERS não foram avaliadas.

O significado da expressão de HOXA10 em endometriose é incerto. Possivelmente, o gene possa ser necessário para o desenvolvimento endometrial "de novo" em localização ectópica ${ }^{15}$. Além disso, níveis variados de expressão em EPT e EPF sugerem que as duas formas da doença possam ter origens distintas ${ }^{46}$. Essas são hipóteses que necessitam de confirmação por novos estudos que avaliem a presença e função de HOXA10 em endometriose, especialmente EPF. 


\subsection{Receptores de estrogênio e endometriose}

O estradiol é o mais potente dos estrogênios e o principal mitógeno para a endometriose, incluindo a EPF. Sua ação é mediada pelos ER, especificamente pelas suas isoformas $\alpha(E R-\alpha)$ e $\beta(E R-\beta)^{47,48}$. O complexo estradiol/receptor ativa genes responsivos e inicia a transcrição de proteínas cujo efeito final é a proliferação celular.

As isoformas ER- $\alpha$ e ER-ß têm $97 \%$ de similaridade e são codificadas por dois genes distintos ${ }^{49}$. A forma clássica ER- $\alpha$ foi clonada em 1986 a partir de células cancerosas mamárias ${ }^{50}$, enquanto ER-ß foi clonada em 1996 a partir de células da próstata de ratos e de testículo humano ${ }^{51,52}$. Outras isoformas específicas de ER-ß já foram descritas em humanos, como $E R-\beta 1^{53}, E R-\beta 2^{54}$, e ER-ßCx ${ }^{55}$, além de isoformas com pequenas variações na porção C-terminal ${ }^{56}$.

O efeito estrogênico tecidual é dependente da expressão proporcional das isoformas, e do contexto em que a célula-alvo se encontra ${ }^{54,57,58}$. Experimentos sugerem que ER- $\alpha$ possa ser mais efetivo que ER- $\beta$ na ativação da transcrição gênica, apesar do estradiol ligar-se a ambos com igual afinidade $49,51,57,59$.

Porém, generalizar resultados obtidos em meios laboratoriais mostrou-se inadequado em pelo menos dois grandes ensaios clínicos com drogas para endometriose ${ }^{60}$. Células do endométrio e de endometriose são essencialmente diferentes, assim como os resultados clínicos obtidos em animais e humanos. 
$A$ isoforma $E R-ß$ já foi estudada em endometriose, porém quase que exclusivamente em EPT e EOV ${ }^{13,61-64}$. Segundo os estudos, sugere-se que ER- $\beta$ tenha uma expressão proporcionalmente elevada nas células estromais de endometriose ${ }^{62-64}$, o que possibilitaria o desenvolvimento de moduladores específicos para o seu tratamento clínico ${ }^{48,62,65}$. Novamente, essas são conclusões generalizadas, de estudos que não avaliaram EPF.

$\mathrm{Na}$ verdade, há poucos estudos sobre a expressão de ER em EPF. Bergqvist et al. ${ }^{66}$ estudaram a expressão de ER e PR-AB por metodologias diferentes em 15 amostras de endometriose, das quais apenas duas eram de ERS.

Calcagno et al. ${ }^{67}$ avaliaram ER e PR-AB em 438 amostras, das quais 13 eram de ERS. Já Samartzis et al. ${ }^{68}$ compararam a expressão de ER-a, ER- $\beta$ e PR-AB entre os três tipos de endometriose pélvica. Ambas as pesquisas demonstraram níveis bastante variáveis de expressão de ER e PR-AB nas diferentes lesões de EPT, EOV e EPF. Isso reforça o conceito de heterogeneidade da doença.

Apesar de as diferentes isoformas de ER serem alvos potenciais para pesquisas sobre a fisiopatologia da doença, ainda não há estudos que avaliem a expressão diferencial de ER- $\alpha$ e ER- $\beta$ exclusivamente em EPF. Esse é um passo necessário para que as conclusões sejam limitadas e aplicadas à EPF, a doença de maior significado clínico.

\subsection{Receptores de progesterona e endometriose}

A progesterona é o segundo hormônio chave na endometriose. Sua 
ação tecidual é mediada pelo receptor de progesterona $P R-A B^{69}$, assim conhecido devido às suas isoformas $A(P R-A)$ e $B(P R-B)^{70-72}$. Elas podem ser estudadas por anticorpos específicos para cada uma delas (PR-A ou PRB), ou por um anticorpo direcionado a ambas (PR-AB).

O PR-AB foi descrito pela primeira vez em 1970 no oviduto de galinhas $^{69}$. A isoforma PR-A é a forma truncada do receptor com 94-kDa, enquanto PR-B representa a sua forma completa com 116-kDa e 164 aminoácidos adicionais na porção $\mathrm{N}$-terminal ${ }^{70-72}$.

Ambas as isoformas são codificadas por um mesmo gene. Elas podem surgir a partir da iniciação da translação em locais alternativos de um mesmo ácido ribonucleico mensageiro $(\mathrm{RNAm})^{73}$, ou pela transcrição em diferentes regiões promotoras do gene ${ }^{74}$. O gene que transcreve PR-AB é regulado pelo estradiol ${ }^{75}$, e contém pelo menos quatro regiões específicas responsivas ao hormônio ${ }^{76,77}$.

Os receptores de progesterona são funcionalmente diferentes e com ações celulares distintas. A isoforma PR-B tende a ser mais potente na ativação da resposta celular, enquanto PR-A pode agir como um repressor de PR-B ${ }^{78,79}$ e de outros receptores hormonais esteroidais, como ER- $\alpha^{79,80}$.

O PR-AB é expresso nas três formas de endometriose pélvica ${ }^{12,14,67,}$ ${ }^{81,82}$ e no TMLP liso adjacente à lesão de $E^{28}{ }^{28}$. Por outro lado, sugere-se que PR-B teria uma expressão mínima ou ausente na endometriose ${ }^{14}$, causada por uma hipermetilação em sua região promotora ${ }^{16}$.

Esse achado poderia explicar a resistência da endometriose à progesterona observada na prática clínica, conferindo ao PR-B uma maior 
importância na doença. Entretanto, essas são conclusões baseadas em estudos realizados exclusivamente em lesões de EPT e EOV ${ }^{14,} 16$ e que necessitam de confirmação em EPF.

De fato, ainda não há estudos sobre a expressão de PR-B em EPF. Possivelmente, isso se deva à impossibilidade que havia para quantificar e diferenciar as isoformas por técnicas imunoistoquímicas ${ }^{66}$. Outra explicação seria a maior dificuldade de obtenção de lesões de EPF, ao contrário de EPT e EOV. Hoje, ambos os obstáculos podem ser superados.

\section{4 elo de ligação entre HOXA10, estrogênios, progesterona e endometriose}

Há poucas substâncias capazes de regularem o gene HOXA10 ${ }^{83}$. Estrogênios e progesterona são alguns exemplos ${ }^{41,84}$, além da vitamina $D^{85}$, testosterona $^{86}$, e o xeno-estrogênio bisfenol-A (BPA) ${ }^{87}$, entre as principais. $O$ estradiol e a progesterona ativam a transcrição de HOXA10, e seus efeitos são aditivos ${ }^{41}$. Essa ativação é mediada pelos seus respectivos receptores ${ }^{88}$.

Há pelo menos dois elementos responsivos ao estrogênio (ERE) no gene HOXA10, que ligam igualmente ER- $\alpha$ e ER- $\aleph^{88}$. Apesar de ambos os ERE ligarem ER- $\alpha$ e ER- $\beta, E R E-1$ tem uma resposta mais robusta na ativação da transcrição de HOXA10 $0^{88}$.

A progesterona também ativa a transcrição de HOXA10. O gene porcino homólogo contém uma região promotora responsiva à progesterona (e também ao estradiol) capaz de ativar a sua transcrição ${ }^{89}$. Em humanos, a 
expressão de HOXA10 no endométrio é máxima durante a fase secretora intermediária, coincidente com o pico sérico progestacional ${ }^{41,90}$.

Assim, as ações coordenadas do estradiol e da progesterona para a ativação de HOXA10 são bem descritas no endométrio adulto ${ }^{41,83}$. Os hormônios ligam-se a seus receptores nucleares, que então ativam a transcrição do gene HOXA10. Este, por sua vez, ativará ou inibirá genesalvo para mediar os efeitos finais dos hormônios. Ainda não se sabe se essa interação ocorreria também nas lesões de endometriose.

A interação entre HOXA10 e estrogênios não se resume à fase adulta. É no período embrionário que seus efeitos são mais evidentes. Nessa fase, os estrogênios regulam a morfogênese de todo o trato genital feminino em ação mediada por ER-a e HOXA10 ${ }^{91}$.

A ação do estrogênio DES exemplifica essa regulação. O DES é um estrogênio teratogênico, cuja ação morfogênica altera a distribuição espacial dos HOX genes que conferem identidade ao ducto paramesonéfrico. Assim, após a exposição ao DES, HOXA9 passa a ser expresso no útero, mas não em trompas; HOXA10 tem expressão diminuída na porção superior do útero; e HOXA11 torna-se globalmente diminuído em todo o útero ${ }^{35}$.

São essas as alterações que podem explicar o útero em forma de "T" observado em mulheres expostas ao $\mathrm{DES}^{34}$. Da mesma forma, um deslocamento caudal da expressão de HOXA10 e HOXA11 poderia ser a causa da adenose vaginal, situação em que o tecido glandular normalmente presente no útero é encontrado em situação ectópica na vagina.

Desenvolvendo o mesmo raciocínio, endometriose significa a 
presença de tecido endometrial em localização ectópica. Conforme mencionado, HOXA10 é expresso em EPT, EOV, EPF e endometriose pulmonar $^{15,46}$. Possivelmente, HOXA10 poderia ter um papel na atribuição da identidade de endometriose a tecidos extrauterinos, ou células paramesonéfricas ectópicas.

De forma "intrigante", a endometriose é descrita em crianças antes da puberdade $^{92}$, em mulheres com agenesia uterina ${ }^{93}$, e em fetos femininos ${ }^{94-96}$. Essas são situações que não podem ser explicadas pela teoria da menstruação retrógrada.

Curiosamente, a endometriose em fetos ocorre com a mesma frequência e nas mesmas localizações observadas na mulher adulta: região retrocervical, ligamentos uterinos ${ }^{95}, 96$, e até mesmo no reto-sigmoide ${ }^{94}$. Curiosamente, o homólogo de HOXA10 foi demonstrado no intestino distal de camundongos fêmeas ainda no período embrionário ${ }^{36}$. Portanto, é possível que o gene HOXA10 possa conferir identidade de endometriose a tecidos indiferenciados ainda durante a embriogênese, talvez sob estímulo estrogênico.

Corroboram essa hipótese achados recentes de estudos experimentais sobre o BPA ${ }^{87,97}$. O BPA é um xeno-estrogênio utilizado em plásticos, selantes dentários e garrafas de policarbonatos, largamente encontrado em nosso meio.

O BPA é um disruptor endócrino da morfogênese, que aumenta a resposta de tecidos sensíveis ao estrogênio por meio da sua ligação a EREs e ativação de HOXA10 ${ }^{87}$. Ele é capaz de aumentar a expressão do RNAm 
de HOXA10 em células tumorais de Ishikawa e em camundongos fêmeas, causando nestes um aumento do lúmen das células epiteliais endometriais e do tamanho uterino ${ }^{87}$.

O achado mais significativo é que o BPA é capaz de induzir endometriose nos embriões desses animais. A exposição pré-natal ao disruptor induz à formação de glândulas e estroma endometriais (que expressam as proteínas ER e HOXA10) no tecido adiposo adjacente ao trato genital em $30 \%$ da prole ${ }^{97}$. Esses achados reforçam a possível interação entre estrogênios e HOXA10 na etiologia da endometriose, ainda durante o período embrionário.

Em resumo, HOXA10, estrogênios e progesterona estão intrinsecamente ligados e envolvidos na fisiopatologia da endometriose. Ainda não há estudos que tenham avaliado suas interações nas lesões de endometriose em si, dentro de um mesmo contexto. O entendimento atual é derivado de estudos experimentais ou ensaios clínicos em que estes foram avaliados de forma isolada.

Há também uma necessidade de mais estudos que avaliem exclusivamente lesões de EPF. A generalização de conclusões obtidas com lesões de EPT e EOV pode ser inadequada e postergar avanços no entendimento da doença.

Portanto, propomos um estudo para avaliar a expressão proteica de HOXA10, ER-a, ER-ß, PR-AB e PR-B em lesões de EPF. Lesões de ERS constituem um modelo ideal para o estudo de EPF por serem macroscopicamente identificáveis e distintas daquelas de EPT ou EOV. Um 
maior entendimento sobre a presença e a interação destes fatores na EPF pode elucidar aspectos importantes da doença. 
2 OBJETIVOS 


\subsection{Objetivo Geral}

Avaliar a expressão proteica do gene homeobox A10 (HOXA10), dos receptores de estrogênio isoformas $\alpha$ (ER- $\alpha)$ e $\beta$ (ER-ß), do receptor de progesterona (PR-AB) e de sua isoforma $B(P R-B)$ no epitélio e no estroma da lesão (LES) e no tecido muscular liso perilesional (TMLP) de endometriose do reto-sigmoide (ERS), durante as fases proliferativa e secretora do ciclo menstrual.

\subsection{Objetivo Específico}

Verificar as correlações, diretas ou inversas, entre as proteínas HOXA10, ER-a, ER-ß, PR-AB e PR-B em LES e no TMLP de ERS, durante as fases proliferativa e secretora do ciclo menstrual. 
3 MÉTODOS 


\subsection{Tipo de estudo}

Estudo observacional retrospectivo tipo coorte histórica. O Comitê de Ética para Análise de Projetos e Pesquisa (CAPPesq) do Hospital das Clínicas da Faculdade de Medicina da Universidade de São Paulo aprovou o protocolo desta pesquisa em 9 de setembro de 2010, sob número 1133/09 (Apêndice A).

\subsection{Casuística}

O grupo de estudo foi composto por pacientes inférteis e consecutivas, atendidas em clínica privada de reprodução humana Huntington Medicina Reprodutiva, em São Paulo/SP. Todas haviam realizado cirurgia vídeo-laparoscópica para ressecção de EPF, incluindo retossigmoidectomia por ERS (Figura 2).

As cirurgias foram realizadas entre os meses de junho de 2003 e julho de 2007 no Hospital e Maternidade Santa Joana e no Hospital Israelita Albert Einstein, em São Paulo/SP. Conforme aprovado pelo CAPPesq, não foram necessários consentimentos pelos comitês de ética destas instituições devido à doação dos blocos de parafina diretamente ao pesquisador, por parte das pacientes. 


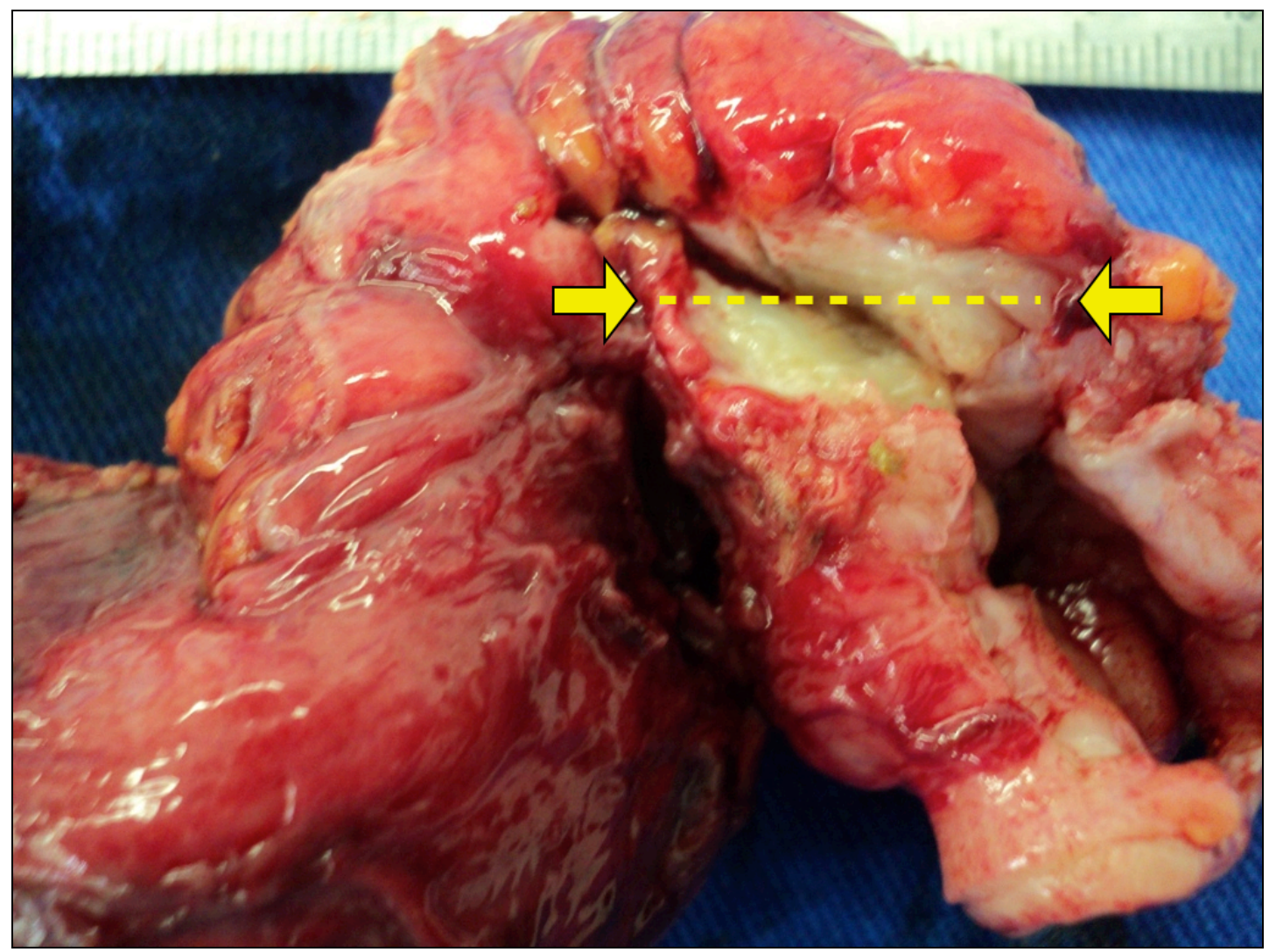

Figura 2. Endometriose de reto-sigmoide. Destaque para o componente fibromuscular da lesão

Anotamos os dados anamnésicos, clínicos e cirúrgicos das pacientes a partir de seus prontuários médicos. Os dados anamnésicos pesquisados foram: idade, tempo de infertilidade em meses, número de cirurgias prévias para ressecção de endometriose, e número de fertilizações in vitro já realizadas.

Em relação aos dados clínicos, pesquisamos a presença de dismenorreia, dispareunia de profundidade, dor pélvica crônica, sinusorragia, sangramento intestinal cíclico, e constipação intestinal previamente à cirurgia.

Quanto aos achados cirúrgicos, anotamos a fase do ciclo menstrual em que se deu a cirurgia, o número e o tamanho em centímetros $(\mathrm{cm})$ das 
lesões de endometriose do reto-sigmoide que foram removidas, além do estadiamento da endometriose segundo a Sociedade Americana para Medicina Reprodutiva (ASRM) $)^{98}$.

Verificamos também a ocorrência de gestações após as cirurgias, e o modo pela qual ocorreram, se naturais ou por técnica de reprodução assistida.

\subsubsection{Critérios de inclusão}

Paciente com endometriose de reto-sigmoide tratada por remoção cirúrgica e comprovada por histologia.

\subsubsection{Critérios de não inclusão}

Ter feito uso de hormônio-terapia nos 90 dias que antecederam a cirurgia.

Não ter a fase do ciclo menstrual determinada no momento da cirurgia.

\subsection{Condições do estudo}

Em um primeiro momento, selecionamos 19 pacientes que preenchiam os critérios de inclusão. Excluímos uma paciente porque a fase do seu ciclo menstrual era inconclusiva no momento da cirurgia (Tabela 1). 
Tabela 1. Características clínico-epidemiológicas de pacientes inférteis submetidas à ressecção laparoscópica de endometriose incluindo retossigmoidectomia jun. 2003 a jul. 2007

\begin{tabular}{|c|c|c|c|}
\hline VARIÁVEL & $\begin{array}{l}\text { VALOR GERAL } \\
\text { Prol | Sec }\end{array}$ & $\begin{array}{c}\mathbf{n} \\
\text { Prol | Sec }\end{array}$ & $\mathbf{p}$ \\
\hline Idade (anos) & $\begin{array}{c}27-38(32,8 \pm 3,3) \\
29-36(32 \pm 2,5) \mid 27-38(33,7 \pm 3,9)\end{array}$ & $\begin{array}{c}18 \\
9 \mid 9\end{array}$ & 0,3 \\
\hline Meses de infertilidade & $\begin{array}{c}12-120(40,9 \pm 29,3) \\
18-120(49,7 \pm 32,3) \mid 12-72(32,1 \pm 24,5)\end{array}$ & $\begin{array}{c}18 \\
9 \mid 9\end{array}$ & 0,161 \\
\hline Cirurgias prévias para endometriose & $\begin{array}{c}0-3(1,1 \pm 0,9) \\
0-2(1,2 \pm 0,8) \mid 0-3(0,9 \pm 1,1)\end{array}$ & $\begin{array}{c}12 \\
7 \mid 5\end{array}$ & 0,387 \\
\hline FIV prévias & $\begin{array}{c}0-5(1,2 \pm 1,6) \\
0-5(1,9 \pm 1,7) \mid 0-3(0,6 \pm 1,1)\end{array}$ & $\begin{array}{c}8 \\
6 \mid 2\end{array}$ & 0,113 \\
\hline Estadiamento ASRM & IV & 18 & \\
\hline Dismenorreia & & $\begin{array}{c}17 \\
8 \mid 9\end{array}$ & $>0,999$ \\
\hline Dispareunia de profundidade & & $\begin{array}{c}10 \\
4 \mid 6\end{array}$ & 0,637 \\
\hline Dor pélvica crônica & & $\begin{array}{c}10 \\
4 \mid 6\end{array}$ & 0,637 \\
\hline Sinusorragia & & $\begin{array}{c}2 \\
0 \mid 2\end{array}$ & 0,471 \\
\hline Sangramento intestinal cíclico & & $\begin{array}{c}2 \\
1 \mid 1\end{array}$ & $>0,999$ \\
\hline Constipação intestinal & & $\begin{array}{c}6 \\
2 \mid 4 \\
\end{array}$ & 0,62 \\
\hline Lesões de ERS por paciente & $\begin{array}{c}1-2(1,4 \pm 0,5) \\
1-2(1,4 \pm 0,5) \mid 1-2(1,3 \pm 0,5)\end{array}$ & $\begin{array}{c}25 \\
13 \mid 12\end{array}$ & 0,73 \\
\hline Tamanho das lesões de ERS $(\mathrm{cm})$ & $\begin{array}{c}1-4(2,3 \pm 0,8) \\
1-3,5(2,2 \pm 0,9) \mid 1-4(2,3 \pm 0,8)\end{array}$ & $\begin{array}{c}25 \\
13 \mid 12\end{array}$ & 0,489 \\
\hline Gestação após cirurgia & & & \\
\hline $\begin{array}{l}\text { Tentativa de concepção } \\
\text { Gestação espontânea } \\
\text { Gestação após FIV }\end{array}$ & $\begin{array}{r}18 \\
7 \\
7\end{array}$ & & \\
\hline
\end{tabular}

$\mathrm{n}$ : número de pacientes ; Prol: fase proliferativa do ciclo menstrual; Sec: fase secretora do ciclo menstrual; ASRM: American Society for Reproductive Medicine; ERS: endometriose de reto-sigmoide; FIV: fertilização in vitro 
Todas as pacientes apresentavam sinais e sintomas de endometriose que justificaram a indicação de tratamento cirúrgico. As cirurgias foram realizadas após orientações sobre riscos e benefícios do procedimento, e mediante consentimento informado para tal.

Realizamos biópsias endometriais durante as cirurgias, e utilizamos os critérios histológicos de Noyes et al. ${ }^{99}$ para determinarmos a fase do ciclo menstrual naquele momento, dito proliferativa ou secretora. Os laboratórios de patologia credenciados de ambos os hospitais processaram os espécimes cirúrgicos de forma habitual.

Todas as pacientes receberam informações detalhadas sobre o estudo. Assinaram, então, o termo de consentimento livre e esclarecido para que os referidos blocos de parafina fossem solicitados junto aos laboratórios de patologia, e nos fossem doados para a realização do estudo (Apêndice B).

\subsection{Confecção dos blocos de microarranjos de tecidos}

Os blocos de parafina foram submetidos a cortes histológicos e corados pela técnica de hematoxilina e eosina. Um patologista experiente selecionou as áreas de melhor representatividade tecidual que continham (a) LES e (b) TMLP de ERS (Figura 3). 


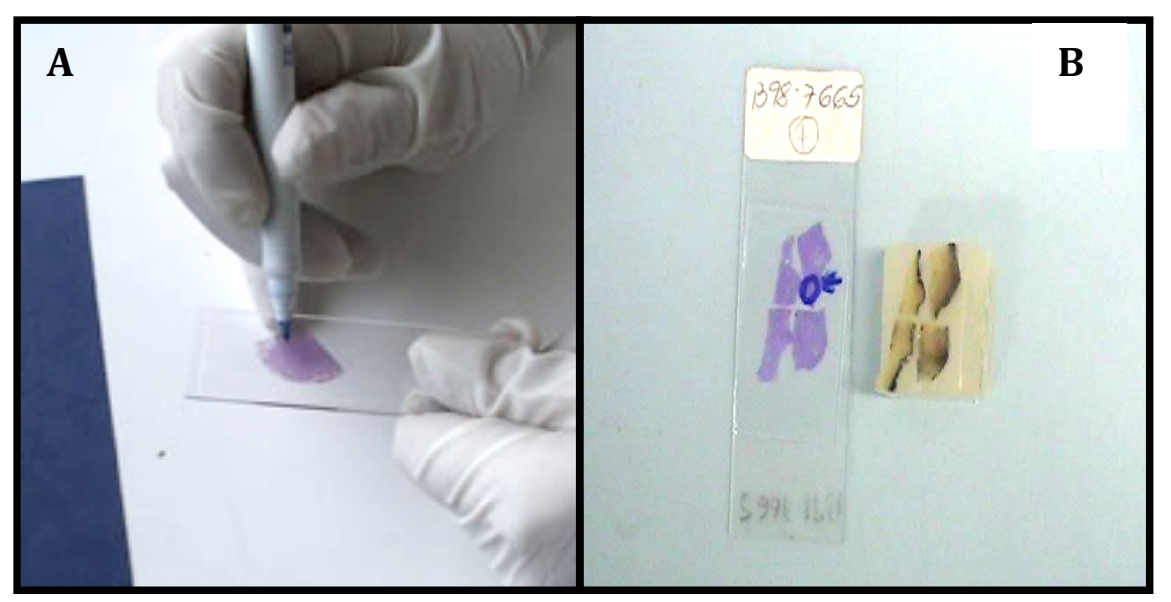

Figura 3. Escolha das regiões para realização da amostragem no bloco doador (A) e identificação na comparação com o bloco de parafina (B)

As áreas selecionadas foram localizadas nos blocos de parafina correspondentes e incluídas na construção de blocos receptores de parafina de microarranjos de tecido, tissue microarray (TMA), segundo técnica previamente descrita ${ }^{100,101}$.

Brevemente, um instrumento de precisão (Beecher Instruments, Silver Spring, MD, EUA) foi utilizado para a construção dos blocos de TMA. Foram feitas perfurações circulares nos blocos de parafina-doador com uma agulha de $0,6 \mathrm{~mm}$ de diâmetro (TMArrayer ${ }^{T M}$ punch MP6-0,6mm, Pathology Devices, Inc., EUA), e as amostras removidas serviram à formação de blocos receptores de tecidos.

Os cilindros foram enxertados nos blocos receptores de parafina a intervalos de $1,0 \mathrm{~mm}$, formando um sistema grade com referências coordenadas nos eixos $\mathrm{x}$ e y. Os blocos receptores foram aquecidos por 10 minutos na temperatura de $60^{\circ} \mathrm{C}$ após a inserção dos cilindros nos blocos receptores (Figura 4). 


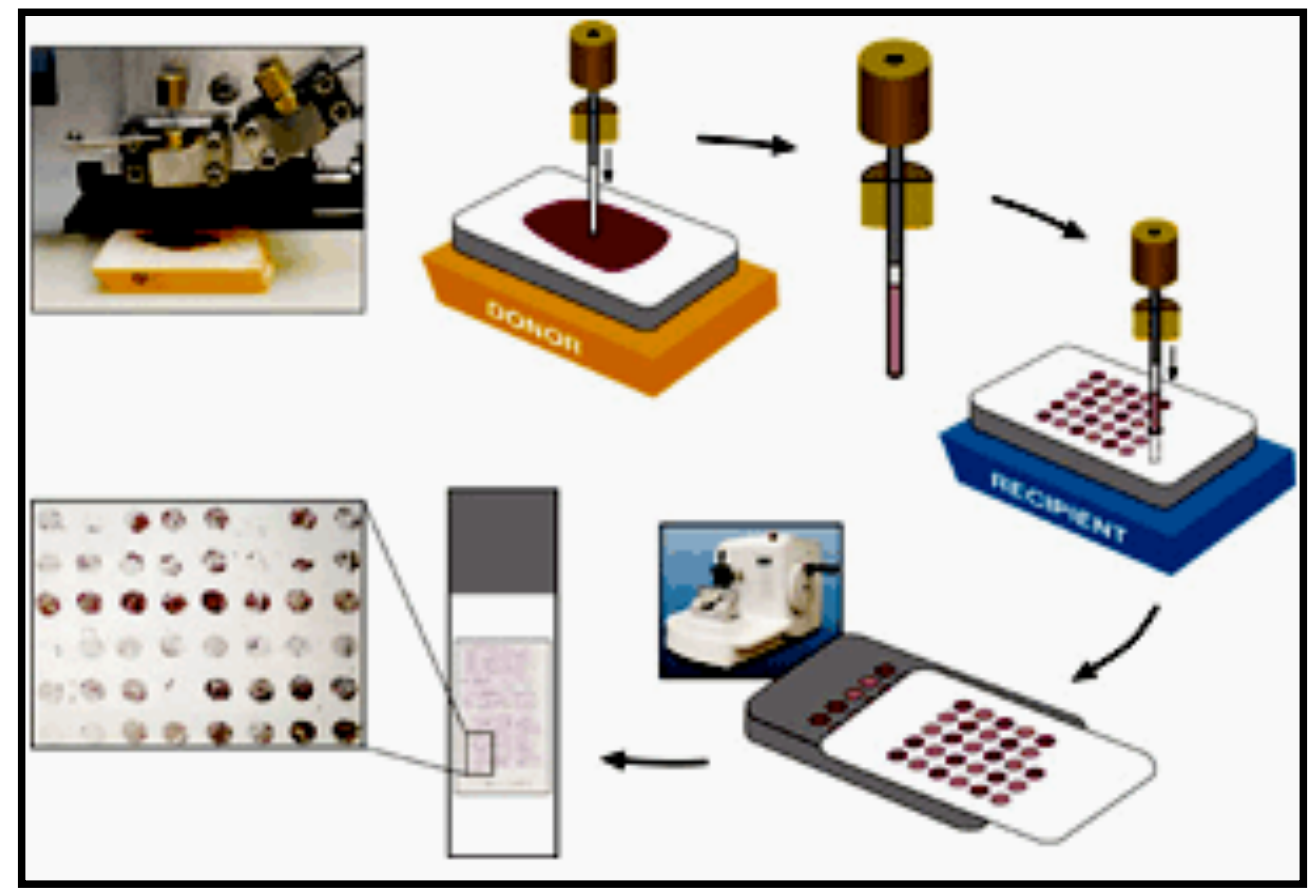

FONTE: Garin, $2006^{102}$

Figura 4. Realização das amostragens de blocos doadores, receptores e montagem dos blocos de microarranjos de tecidos

Resultaram quatro blocos de parafina de TMA, cada um com 285 amostras, denominadas spots (Figura 5). Os blocos de TMA foram submetidos a cortes histológicos de $4 \mu \mathrm{m}$ em micrótomo convencional e técnica padronizada, com lâminas apropriadas da marca Starfrost ${ }^{\circledR}$ slides. Esses cortes foram depositados sobre lâmina de microscopia e processados por reações imunoistoquímicas. 


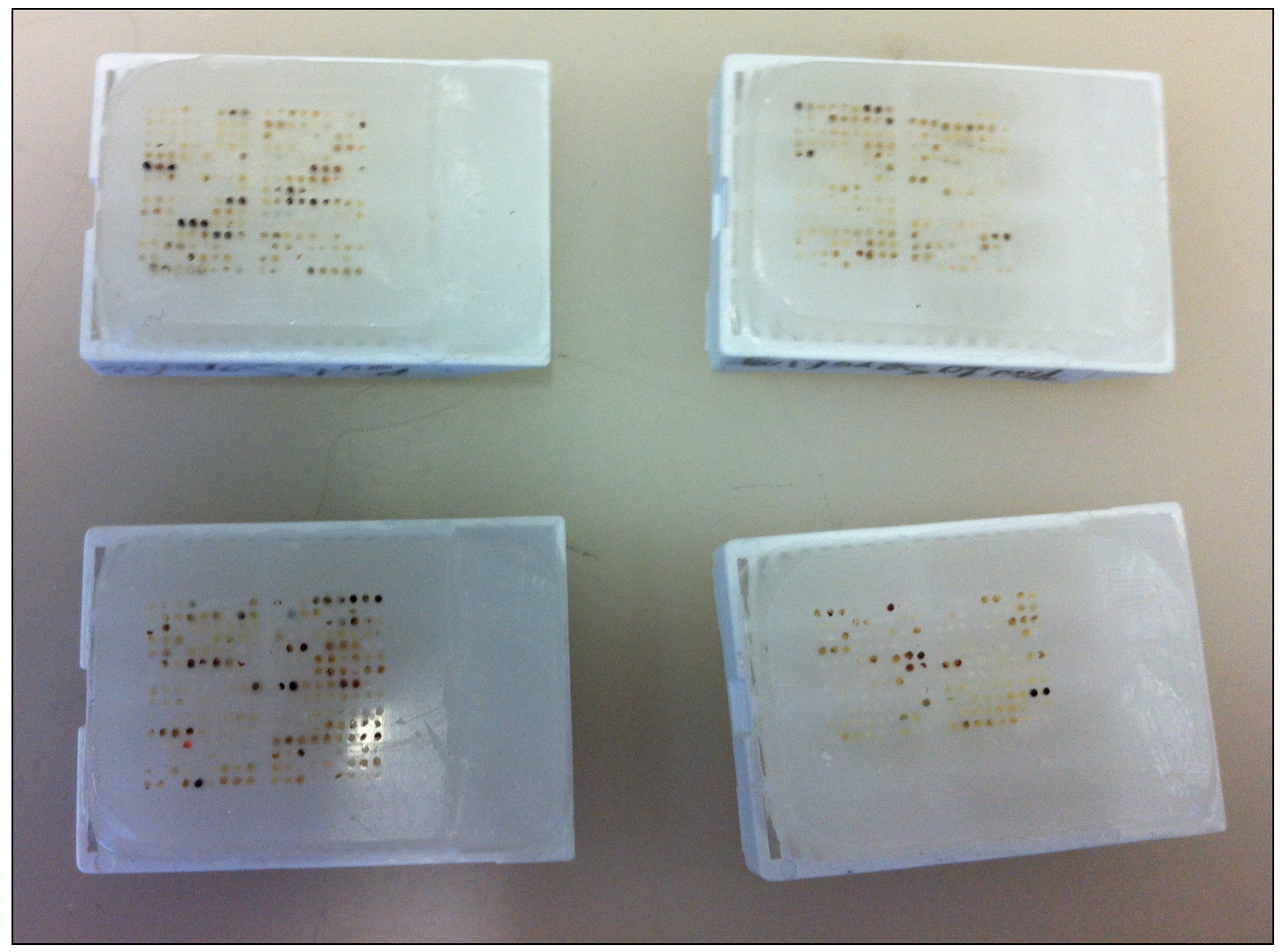

Figura 5. Amostras de 18 pacientes resultaram em quatro blocos de TMA, cada um com 285 spots

\subsection{Reações de imunoistoquímica}

As reações imunoistoquímicas com os anticorpos para as proteínas HOXA10, ER- $\alpha, E R-ß, P R-A B$ e PR-B foram processadas em duplicata. Um protocolo único de recuperação antigênica foi utilizado, como a seguir.

Primeiramente, as lâminas foram incubadas em solução de ácido cítrico 0,21\% e pH 6,0 em panela de pressão, por 8 minutos após obtenção da pressão. A seguir, foram lavadas em água destilada após esfriamento à temperatura ambiente por 20 minutos. Por último, foi promovido o bloqueio da peroxidase endógena e imersão em solução salina tamponada com fosfato (PBS). 
Posteriormente, as lâminas foram incubadas com o anticorpo primário diluído em PBS em proporção pré-estabelecida (Quadro 1). Um substrato cromógeno, a 3'-3'-diaminobenzidina (DAB, Sigma, St. Louis, EUA, Ref.: 5637) foi utilizado para a revelação. Os cortes foram então contra-corados com Hematoxilina de Harris (Merck, Alemanha, Ref.: 1082530500).

Quadro 1. Tipo, procedência e diluição dos anticorpos monoclonais utilizados nas reações de imunoistoquímica

\begin{tabular}{|llcc|}
\hline ANTICORPO & PROCEDÊNCIA & DILUIÇÃO & REFERÊNCIA \\
\hline HOXA10 & Santa Cruz & $1: 200$ & Sc-17159 \\
& Biotechnology & & \\
ER- $\alpha$ & Dako & $1: 200$ & M3634 \\
ER-ß & AbCam & $1: 100$ & ab288 \\
PR-AB & Dako & $1: 50$ & M3569 \\
PR-B & Neomarkers & $1: 100$ & hPRa7 \\
\hline
\end{tabular}

Utilizamos cortes histológicos de tecidos previamente reconhecidos como controle positivo para os anticorpos testados. Tecido endometrial foi utilizado como controle para a proteína HOXA10, enquanto tecido de câncer de mama foi utilizado para as proteínas ER-a, ER-ß, PR-AB e PR-B. Os controles negativos foram realizados através da não utilização do anticorpo primário.

\subsection{Interpretação imunoistoquímica por microscopia ótica}

Dois patologistas experientes analisaram as lâminas conjuntamente por microscopia ótica (MO). Nessa fase, não foi possível analisarmos a proteína ER-ß devido às condições das lâminas. 
Construímos uma tabela em que cada spot foi classificado como sendo de LES ou TMLP, de acordo com o mapa original da construção do TMA.

Então, subdividimos os spots de ambas as categorias como contendo tecido glandular ou estromal, conforme observado à MO. No TMLP, limitamos nossas análises aos componentes glandular e estromal entremeados no músculo liso. Por fim, todas as amostras foram classificadas como provenientes de fase proliferativa ou secretora do ciclo menstrual (Anexos A e B).

Obtivemos spots representativos de 16 das 18 pacientes para análise das proteínas durante a fase proliferativa, e de 15 das 18 durante a fase secretora.

Consideramos suficiente um mínimo de $10 \%$ do diâmetro total de um core/caso contendo tecido representativo de LES ou TMLP. Analisamos a imunopositividade pela expressão do depósito cromógeno marrom de DAB nas células.

Utilizamos os critérios modificados Allred ${ }^{103}$ para esta análise. Obtivemos um resultado ("escore") de 0 a 12 baseado na intensidade e frequência da expressão de cada marcador, como a seguir.

Primeiro, estabelecemos a intensidade da marcação e a classificamos como: 0) negativa; 1) fraca; 2) moderada; e 3) forte. Depois, estabelecemos a frequência (percentual) da marcação e a classificamos como: 0) < 1\%; 1) 1- 10\%; 2) $11-50 \%$; 3) 51-90\%; 4) >90\%. 
O "escore" final foi o produto da intensidade e frequência da marcação, e classificada como: 1) negativa: 0 a 1; 2) positiva fraca: 2 a 4 ; 3) positiva média: 5 a 8; ou 4) positiva forte: 9 a 12 (Quadro 2).

Quadro 2. Critérios modificados de Allred para quantificação de marcação imunoistoquímica

\begin{tabular}{|c|c|c|c|c|c|}
\hline Intensidade & 0) negativo & 1) fraca & 2) moderada & 3) forte & \\
\hline Frequência \% & $0)<1$ & 1) $1-10$ & 2) $11-50$ & 3) $51-90$ & 4) $>90$ \\
\hline
\end{tabular}

FONTE: Allred, $1998^{103}$

\subsection{Interpretação imunoistoquímica por análise morfométrica}

$\mathrm{Na}$ segunda fase do estudo, escaneamos inteiramente as lâminas de TMA marcadas com os anticorpos para as proteínas HOXA10, ER- $\alpha$, ER-ß, PR-AB e PR-B. Para tal, utilizamos o aparelho Pannoramic MIDI 3DHISTECH (3DHISTECH Ltd, Hungria).

Nessa fase, o escaneamento das lâminas de ER-a não foi satisfatório, e optamos por não analisá-las.

Quantificamos as marcações das imagens com o software Pannoramic Viewer, versão 1.15.1 (3DHistech Ltd, Hungria), específico para o escâner utilizado (Figura 6). 


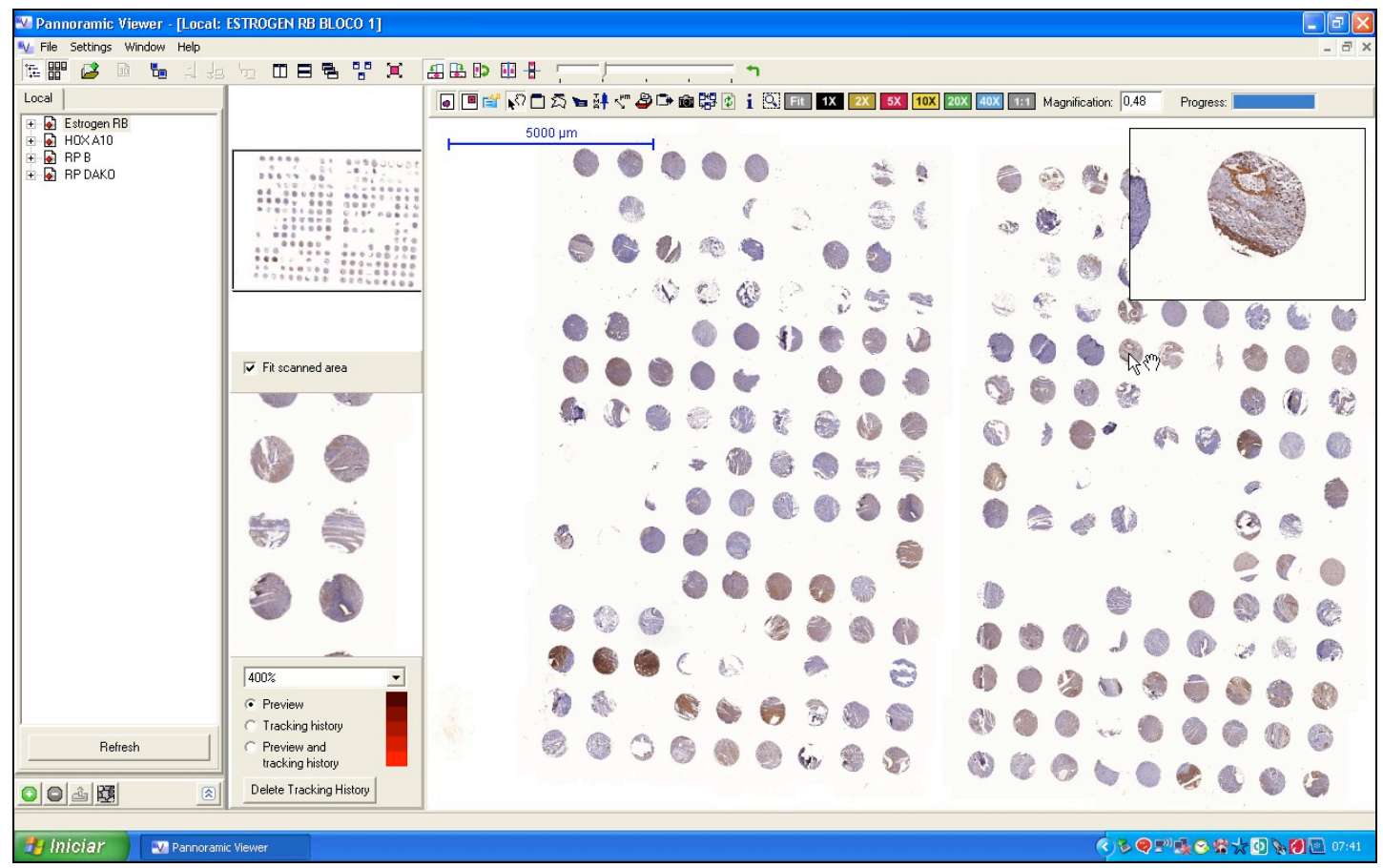

Figura 6. O software Pannoramic Viewer foi utilizado para a análise morfométrica das imagens digitalizadas das lâminas de TMA

O software foi utilizado para delimitar manualmente a área (morfometria) de cada spot. Nesse processo, excluímos as áreas dos spots que não continham tecido, para que não fossem incluídas na análise das imagens digitalizadas.

Então, determinamos o padrão de coloração positiva em cada lâmina a ser usado como referência durante a análise. A partir dessa informação, o software quantificou a área correspondente ao padrão de cor estabelecido de cada spot. Dessa forma, reduzimos a possibilidade de que artefatos e o fundo da lâmina fossem interpretados como marcação positiva.

O software determinou resultados numéricos equivalentes à área total do spot (ATS) e à área de marcação positiva do spot (AMS) de cada proteína. Para a interpretação dos resultados, consideramos a área 
proporcional (em percentual) marcada, segundo a fórmula (AMS / ATS) x 100.

De forma semelhante à análise por $\mathrm{MO}$, construímos uma tabela onde cada spot foi classificado como sendo de LES ou TMLP, de acordo com mapa original da construção do TMA.

A seguir, classificamos as amostras como provenientes de fase proliferativa ou secretora do ciclo menstrual (Anexos C e D).

Obtivemos spots representativos de 15 das 18 pacientes para análise das proteínas durante a fase proliferativa, e de 17 das 18 durante a fase secretora.

Quando consideramos conjuntamente as análises morfométrica (AM) e por MO, verificamos que cada paciente contribuiu com amostras para pelo menos uma das análises.

O software utilizado AM avaliou o spot em sua totalidade, e não permitiu uma estratificação quantitativa e individualizada por tecido glandular, estromal, ou muscular liso. Portanto, consideramos as amostras de TMLP como um todo e não individualizada por compartimentos.

\subsection{Análise estatística}

Classificamos as pacientes em dois grupos, segundo a fase do ciclo menstrual em que foram operadas. Analisamos seus dados clínicos, epidemiológicos e cirúrgicos qualitativos pelo teste de associação de Fisher, e os dados numéricos quantitativos pelos testes de comparação de t-student ou Mann-Whitney. 
As medidas resumo (média e desvio padrão) de todas as proteínas foram tabuladas de acordo com a localização e a fase do ciclo menstrual. llustramos seus resultados em gráficos de barras que representaram os valores médios e seus respectivos erros padrão.

Utilizamos a distribuição marginal Poisson com função de ligação identidade $^{104}$ para avaliar resultados da MO. Os resultados da AM foram analisados com distribuição marginal Gama e função de ligação identidade $^{104}$. A aplicação da distribuição marginal Gama permitiu desconsiderar valores extremos que fossem porventura encontrados na curva de distribuição dos dados.

Posteriormente, avaliamos o comportamento médio da expressão de cada proteína em ambas as fases (proliferativa e secretora) e locais (LES e TMLP) de expressão (interação fase e local, ou fase $x$ local), para identificarmos um padrão de comportamento geral de expressão. Para isso, utilizamos equações de estimação generalizadas com matriz de correlação permutável entre as fases e os locais de expressão.

Para os modelos que apresentaram significância estatística na análise, realizamos comparações múltiplas de Bonferroni para verificarmos entre quais locais anatômicos e/ou fases do ciclo ocorreram as diferenças nas variáveis.

Por fim, calculamos as correlações de Spearman entre cada um dos parâmetros avaliados por MO e AM, para verificarmos a existência e o tipo de relação (direta ou inversa) entre eles. 
Utilizamos os softwares Excel 2003 para Windows (Microsoft, EUA) e Statistical Package for Social Science (SPSS) 17.0 para Windows (IBM, EUA) para as análises estatísticas. Realizamos os testes com nível de significância de 5\%. 
4 RESULTADOS 
4.1 Resultados das expressões imunoistoquímicas das proteínas HOXA10, ER- $\alpha$, PR-AB, PR-B segundo análise por microscopia ótica

O Gráfico 1 demonstra os resultados das expressões das proteínas HOXA10, ER- $\alpha$, PR-AB, e PR-B analisadas por MO durante a fase proliferativa do ciclo menstrual. Os resultados foram individualizados por LES e TMLP, e pelos compartimentos glandular e estromal.

Gráfico 1. Valores médios e respectivos erros padrão das expressões imunoistoquímicas das proteínas HOXA10, ER- $\alpha$, PR-AB e PR-B em lesão e tecido perilesional de endometriose de reto-sigmoide segundo análise por microscopia ótica, durante a fase proliferativa do ciclo menstrual

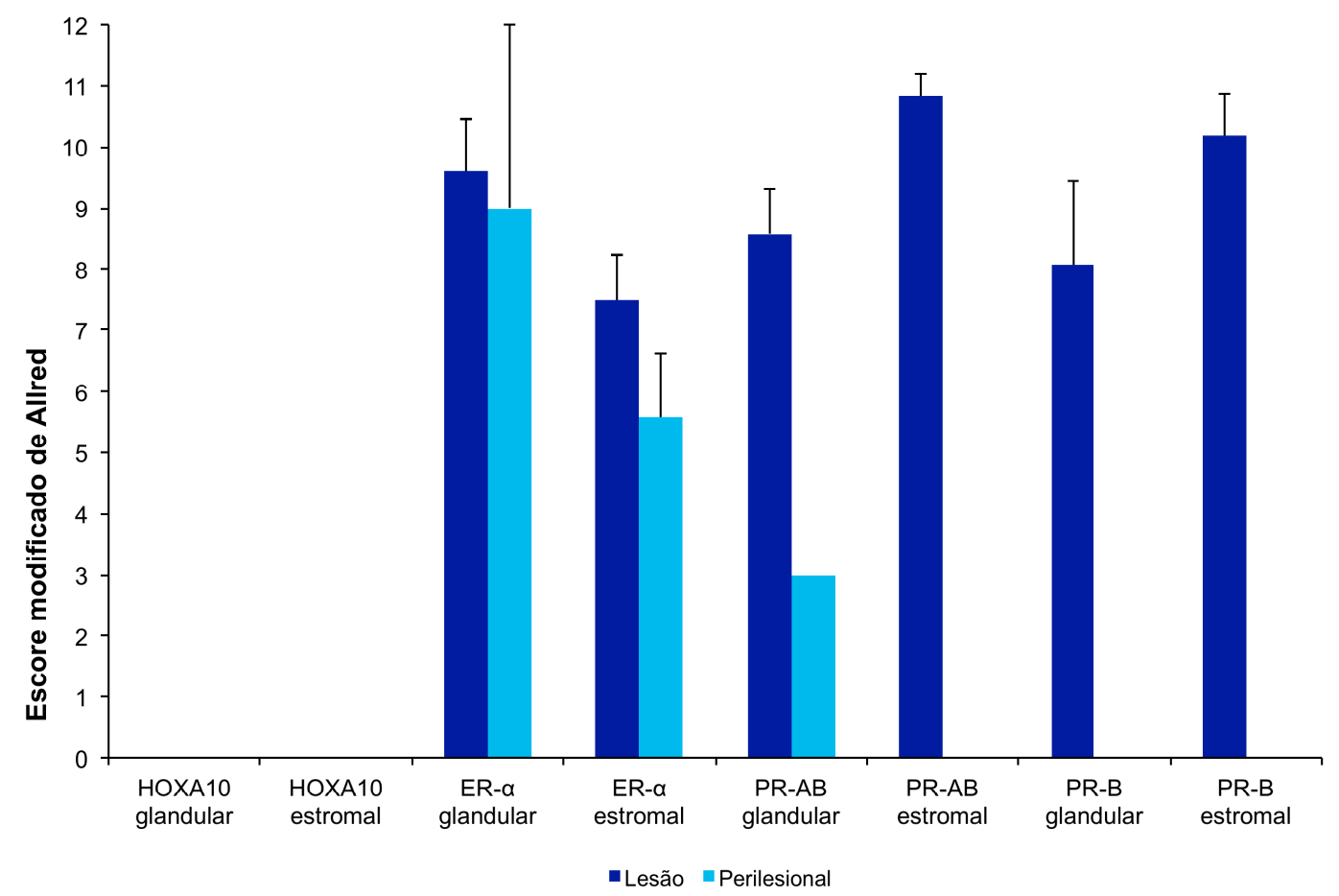


Da mesma forma, o Gráfico 2 demonstra os resultados das expressões dessas proteínas individualizadas por LES e TMLP e por tecido glandular e estromal, porém durante a fase secretora do ciclo menstrual.

Gráfico 2. Valores médios e respectivos erros padrão das expressões imunoistoquímicas das proteínas HOXA10, ER- $\alpha$, PR-AB e PR-B em lesão e tecido perilesional de endometriose de reto-sigmoide segundo análise por microscopia ótica, durante a fase secretora do ciclo menstrual

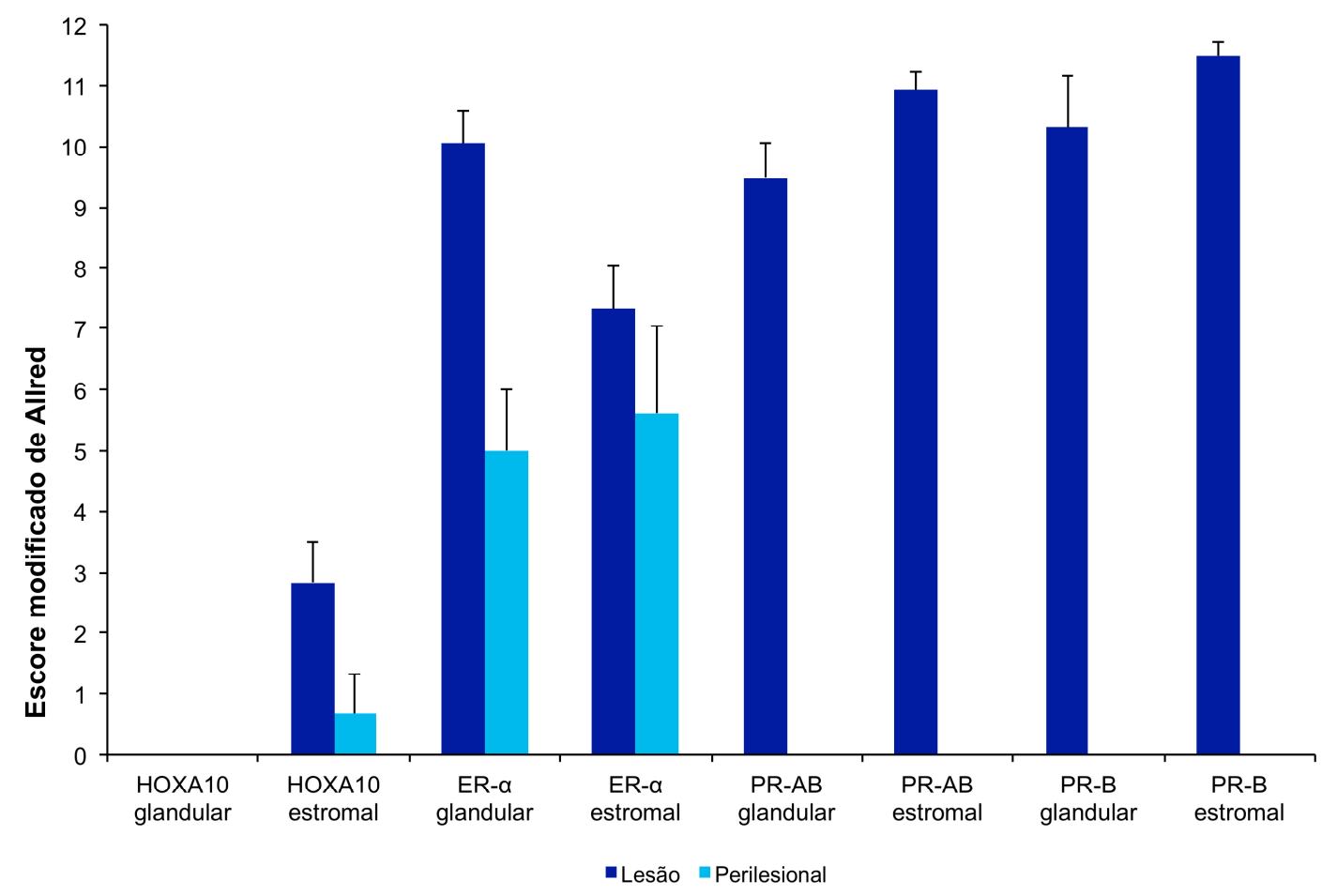

A proteína HOXA10 teve expressão positiva fraca no estroma de LES e TMLP durante a fase secretora, e não foi expressa em glândulas e nem durante a fase proliferativa.

A proteína ER-a teve expressões positiva média e forte em glândula e estroma de LES e TMLP, em ambas as fases do ciclo menstrual. 
Houve expressão positiva fraca da proteína PR-AB em glândulas do TMLP durante a fase proliferativa, e ausência de expressão desta durante a fase secretora. A proteína PR-B teve expressão positiva forte em LES tanto em glândula como em estroma e durante ambas as fases do ciclo menstrual, sendo que não foi expressa no TMLP em nenhuma das fases.

Quando positivas, a expressão de todas as proteínas sempre foi maior na LES do que no TMLP, em ambas as fases do ciclo menstrual.

Na Tabela 2 estão descritas as comparações das proteínas HOXA10, ER-a, PR-AB, e PR-B em glândulas e estroma de LES e TMLP quando avaliadas por $\mathrm{MO}$, segundo a interação entre fase do ciclo menstrual e local de expressão, e individualizadas por fase e local.

Tabela 2. Comparações das expressões das proteínas HOXA10, ER-a, PR-AB e PR-B em endometriose de reto-sigmoide analisadas por microscopia ótica, segundo a interação entre fase do ciclo menstrual e local de expressão, e individualizadas por fase e local

\begin{tabular}{lcccc}
\hline Marcador & Fator & $\begin{array}{c}\text { Estatística de } \\
\text { teste (Wald) }\end{array}$ & gl & $\mathbf{p}$ \\
\hline \hline HOXA10 estromal & Local & 6,69 & 1 & $\mathbf{0 , 0 1 0}$ \\
\hline \multirow{2}{*}{ ER- $\alpha$ glandular } & Fase & 0,72 & 1 & 0,396 \\
& Local & 0,28 & 1 & 0,600 \\
& Fase $x$ Local & 0,65 & 1 & 0,419 \\
\hline \multirow{2}{*}{ ER- $\alpha$ estromal } & Fase & 0,36 & 1 & 0,548 \\
& Local & 8,19 & 1 & $\mathbf{0 , 0 0 4}$ \\
& Fase x Local & 0,02 & 1 & 0,887 \\
\hline \multirow{2}{*}{ PR-AB glandular } & Fase & 0,27 & 1 & 0,606 \\
& Local & 8,87 & 1 & $\mathbf{0 , 0 0 3}$ \\
\hline PR-AB estromal & Fase & 0,03 & 1 & 0,868 \\
\hline PR-B glandular & Fase & 5,15 & 1 & $\mathbf{0 , 0 2 3}$ \\
\hline PR-B estromal & Fase & 5,10 & 1 & $\mathbf{0 , 0 2 4}$ \\
\hline
\end{tabular}

Fase: fases proliferativa e secretora do ciclo menstrual; local: lesão e tecido muscular liso perilesional de endometriose do reto-sigmoide; fase x local: interação fase versus local: gl: grau de liberdade; P: probabilidade do resultado ser devido ao acaso 
A ausência de expressão das proteínas em determinados locais ou fases impossibilitou a realização do teste para o fator fase (HOXA10 glandular), fator local (PR-B glandular e PR-B estromal), e fator de interação fase e local (PR-AB glandular e PR-AB estromal).

Segundo a análise, as proteínas HOXA10 estromal, ER-a estromal e PR-AB glandular apresentaram diferenças médias de expressão estatisticamente diferentes entre LES e TMLP na ERS, independentemente da fase proliferativa ou secretora do ciclo menstrual.

Já a proteína PR-B, tanto glandular como estromal, apresentou diferença média de expressão estatisticamente diferente entre as fases proliferativa e secretora do ciclo menstrual, independentemente da expressão em LES e TMLP na ERS.

$\mathrm{Na}$ Tabela 3 encontramos os resultados das comparações múltiplas de Bonferroni realizadas para os parâmetros que apresentaram diferenças estatisticamente significativas na análise anterior. 
Tabela 3. Comparações múltiplas das expressões imunoistoquímicas das proteínas HOXA10 estromal, ER- $\alpha$ estromal, PR-AB glandular, PR-B glandular e PR-B estromal analisadas por microscopia ótica, segundo o local de expressão e a fase do ciclo menstrual

\begin{tabular}{|c|c|c|c|c|c|c|}
\hline \multirow{2}{*}{ Marcador } & \multirow{2}{*}{ Comparação } & \multirow{2}{*}{$\begin{array}{c}\begin{array}{c}\text { Diferença } \\
\text { Média }\end{array} \\
\end{array}$} & \multirow{2}{*}{ Erro Padrão } & \multirow{2}{*}{$\mathbf{p}$} & \multicolumn{2}{|c|}{ IC (95\%) } \\
\hline & & & & & Inferior & Superior \\
\hline HOXA10 estromal & Lesão x Perilesional & 2,47 & 0,77 & 0,010 & 0,96 & 3,99 \\
\hline ER- $\alpha$ estromal & Lesão x Perilesional & 1,78 & 0,61 & 0,003 & 0,59 & 2,96 \\
\hline PR-AB glandular & Lesão x Perilesional & 5,84 & 1,82 & 0,001 & 2,28 & 9,40 \\
\hline PR-B glandular & Proliferativa $\times$ Secretora & $-2,14$ & 0,94 & 0,023 & $-3,98$ & $-0,29$ \\
\hline PR-B estromal & Proliferativa x Secretora & $-1,66$ & 0,73 & 0,024 & $-3,10$ & $-0,22$ \\
\hline
\end{tabular}

P: probabilidade do resultado ser devido ao acaso; IC: intervalo de confiança

De acordo com as comparações, as proteínas HOXA10 estromal, ER$\alpha$ estromal e PR-AB glandular tiveram expressões estatisticamente maiores na LES do que no TMLP, independentemente da fase do ciclo menstrual.

Já a proteína PR-B, tanto glandular como estromal, teve expressão estatisticamente maior durante a fase secretora do ciclo menstrual, independentemente de estar localizada na LES ou no TMLP.

A Tabela 4 descreve as correlações diretas e inversas entre as proteínas HOXA10, ER- $\alpha$, PR-AB e PR-B, e as probabilidades de essas correlações serem devidas ao acaso (valor de $\mathrm{P}$ ), segundo análise por $\mathrm{MO}$. As correlações foram estabelecidas independentemente da fase do ciclo ou local de expressão destas na ERS. 
Tabela 4. Correlações entre as expressões imunoistoquímicas das proteínas HOXA10, ER-a, PR-AB e PR-B analisadas por microscopia ótica em endometriose de reto-sigmoide

\begin{tabular}{|c|c|c|c|c|c|c|c|}
\hline \multicolumn{2}{|c|}{ Correlação } & $\begin{array}{l}\text { HOXA10 } \\
\text { estromal } \\
\end{array}$ & $\begin{array}{c}\text { ER- } \alpha \\
\text { glandular }\end{array}$ & $\begin{array}{c}\text { ER- } \alpha \\
\text { estromal }\end{array}$ & $\begin{array}{c}\text { PR-AB } \\
\text { glandular }\end{array}$ & $\begin{array}{c}\text { PR-AB } \\
\text { estromal }\end{array}$ & $\begin{array}{c}\text { PR-B } \\
\text { glandular }\end{array}$ \\
\hline $\begin{array}{l}\text { ER- } \alpha \\
\text { glandular }\end{array}$ & $\begin{array}{l}r \\
p \\
N\end{array}$ & 2 & & & & & \\
\hline $\begin{array}{l}\text { ER- } \alpha \\
\text { estromal }\end{array}$ & $r$ & & $\begin{array}{l}0,447 \\
\mathbf{0 , 0 0 3}\end{array}$ & & & & \\
\hline $\begin{array}{l}\text { PR-AB } \\
\text { glandular }\end{array}$ & $\begin{array}{l}N \\
r \\
p \\
N\end{array}$ & $\begin{array}{l}2 \\
1 \\
4\end{array}$ & $\begin{array}{c}41 \\
-0,092 \\
0,634 \\
29\end{array}$ & $\begin{array}{c}-0,373 \\
\mathbf{0 , 0 3 2} \\
33\end{array}$ & & & \\
\hline $\begin{array}{l}\text { PR-AB } \\
\text { estromal }\end{array}$ & $\begin{array}{l}r \\
p \\
N\end{array}$ & $\begin{array}{c}0,395 \\
0,510 \\
5\end{array}$ & $\begin{array}{c}-0,402 \\
\mathbf{0 , 0 2 8} \\
30\end{array}$ & $\begin{array}{c}-0,022 \\
0,902 \\
35\end{array}$ & $\begin{array}{c}-0,281 \\
0,051 \\
49\end{array}$ & & \\
\hline $\begin{array}{l}\text { PR-B } \\
\text { glandular }\end{array}$ & $\begin{array}{l}r \\
p \\
N\end{array}$ & 2 & $\begin{array}{c}-0,184 \\
0,496 \\
16\end{array}$ & $\begin{array}{c}-0,333 \\
0,192 \\
17\end{array}$ & $\begin{array}{c}0,600 \\
0,001 \\
27\end{array}$ & $\begin{array}{c}-0,052 \\
0,777 \\
32\end{array}$ & \\
\hline $\begin{array}{l}\text { PR-B } \\
\text { estromal }\end{array}$ & $\begin{array}{l}\mathrm{r} \\
\mathrm{p} \\
\mathrm{N}\end{array}$ & $\begin{array}{c}0,544 \\
0,456 \\
4\end{array}$ & $\begin{array}{c}0,116 \\
0,606 \\
22\end{array}$ & $\begin{array}{c}-0,085 \\
0,692 \\
24\end{array}$ & $\begin{array}{c}-0,162 \\
0,351 \\
35\end{array}$ & $\begin{array}{c}0,320 \\
\mathbf{0 , 0 3 6} \\
43\end{array}$ & $\begin{array}{c}-0,077 \\
0,663 \\
34\end{array}$ \\
\hline
\end{tabular}

r: estimativa da correlação; P: probabilidade do resultado ser devido ao acaso; N: número de amostras avaliadas

Houve correlação direta estatisticamente significativa entre as expressões das proteínas ER- $\alpha$ glandular e estromal $(r=0,447 ; P=0,003)$, entre PR-AB e PR-B glandulares $(r=0,600 ; P=0,001)$, e entre PR-AB e PRB estromais $(r=0,320 ; P=0,036)$.

Por outro lado, houve correlação inversa estatisticamente significativa entre as expressões das proteínas ER-a glandular e PR-AB estromal $(r=-0,402 ; P=0,028)$ e entre ER- $\alpha$ estromal e PR-AB glandular $(r=-0,373$; $P=0,032)$. 
4.2 Resultados das expressões imunoistoquímicas das proteínas HOXA10, ER-ß, PR-AB e PR-B segundo análise morfométrica

O Gráfico 3 demonstra os resultados das expressões das proteínas HOXA10, ER-ß, PR-AB e PR-B quando avaliadas por AM durante a fase proliferativa do ciclo menstrual, individualizados por LES e TMLP.

Gráfico 3 - Valores médios e respectivos erros padrão das expressões imunoistoquímicas das proteínas HOXA10, ER-ß, PR-AB e PR-B em lesão e tecido perilesional de endometriose de reto-sigmoide segundo análise morfométrica, durante a fase proliferativa do ciclo menstrual

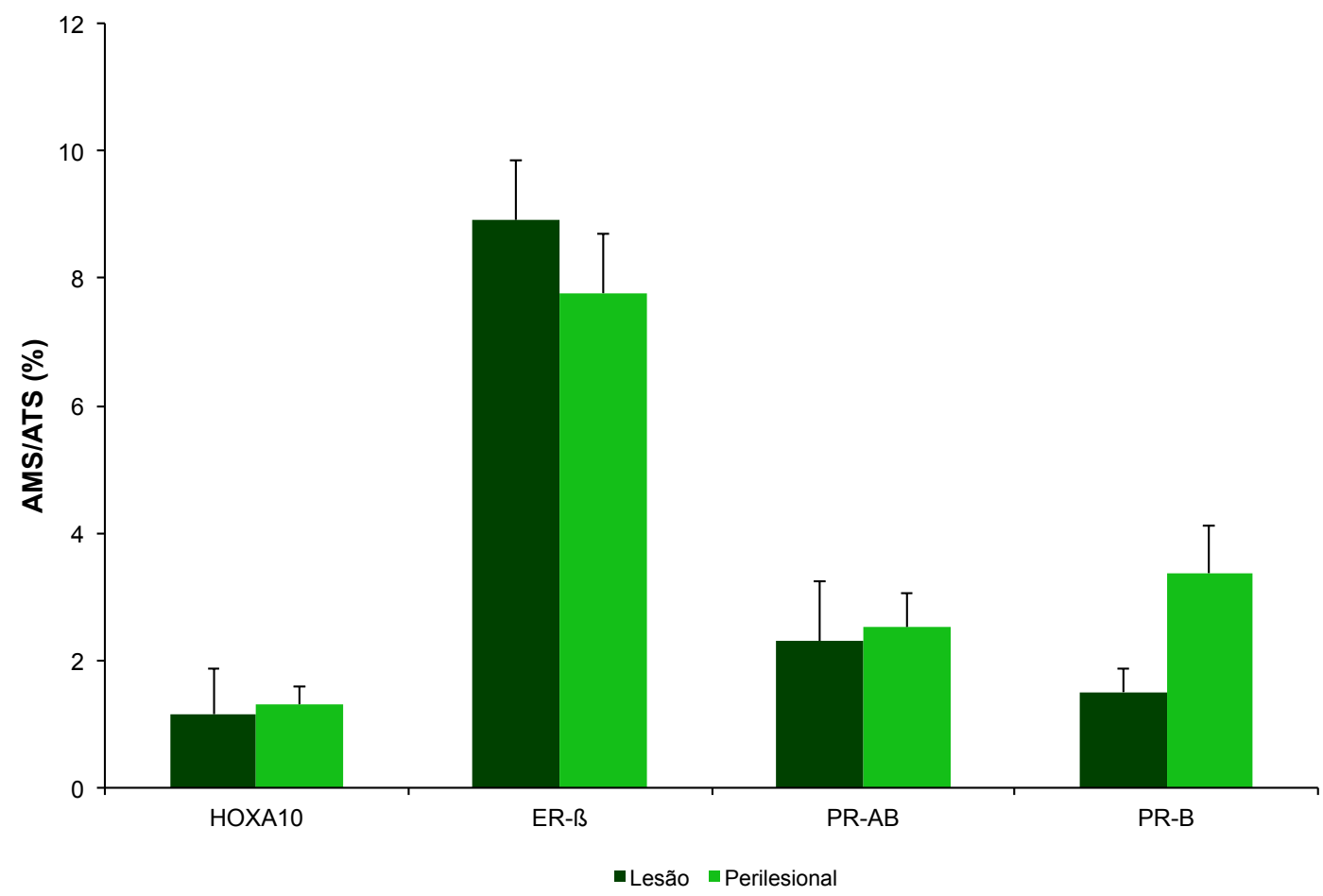

AMS = área marcada do spot ATS = área total do spot 
O Gráfico 4 demonstra os resultados das expressões imunoistoquímicas dessas proteínas individualizadas por LES e TMLP, durante a fase secretora do ciclo menstrual.

Gráfico 4 - Valores médios e respectivos erros padrão das expressões imunoistoquímicas das proteínas HOXA10, ER-ß, PR-AB e PR-B em lesão e tecido perilesional de endometriose de reto-sigmoide segundo análise morfométrica, durante a fase secretora do ciclo menstrual

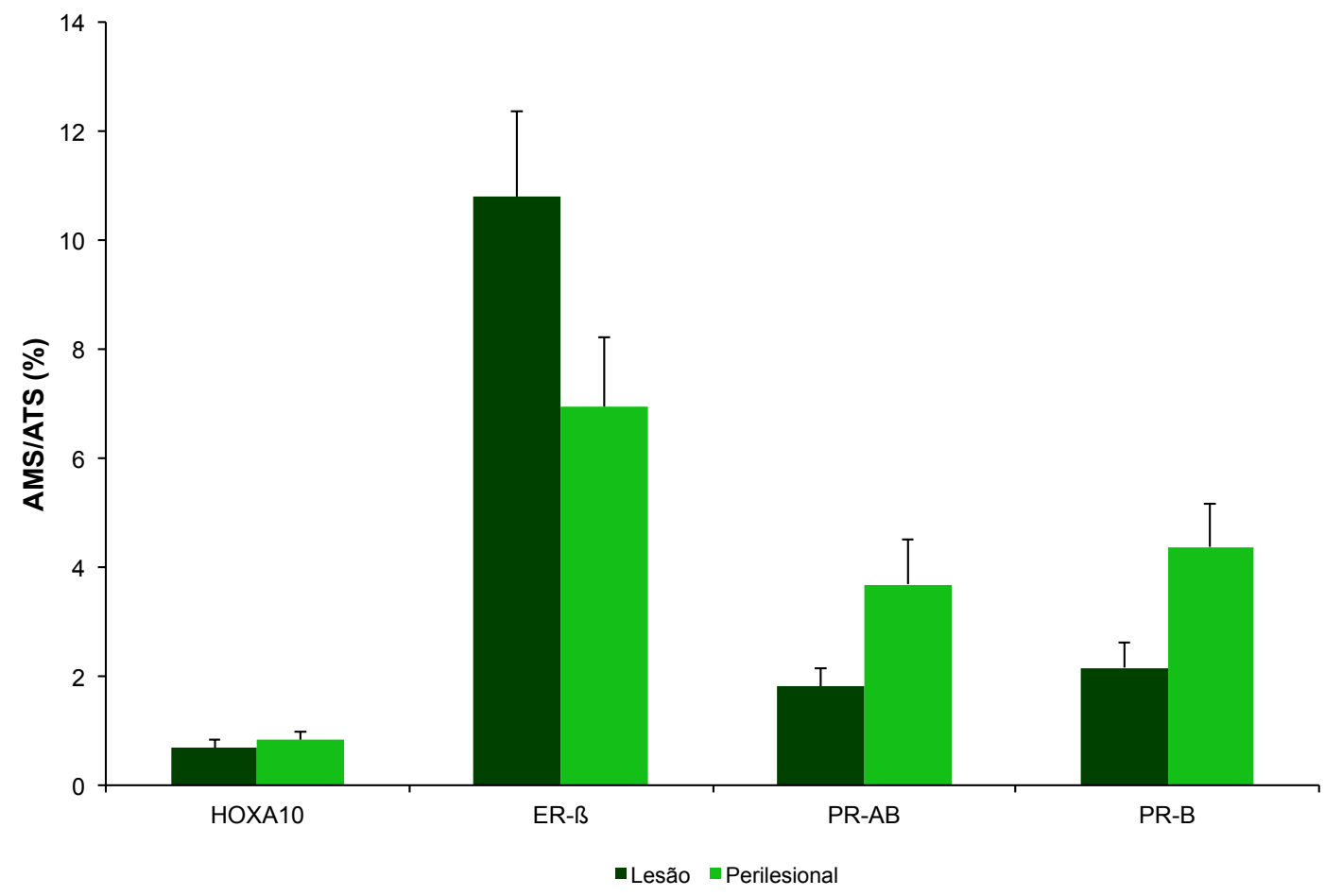

AMS = área marcada do spot ATS = área total do spot 
Na Tabela 5 estão descritas as comparações das proteínas HOXA10, ER-ß, PR-AB, e PR-B em glândulas e estroma de LES e TMLP quando avaliadas por AM, segundo a interação entre fase e local do ciclo menstrual, e individualizadas por fase e local.

Tabela 5 -Comparações das expressões imunoistoquímicas das proteínas HOXA10, ER-ß, PR-AB e PR-B em endometriose de reto-sigmoide avaliadas por análise morfométrica, segundo a interação entre fase do ciclo menstrual e local de expressão, e individualizadas por fase e local

\begin{tabular}{lcccc}
\hline Proteína & Fator & $\begin{array}{c}\text { Estatística de } \\
\text { teste (Wald) }\end{array}$ & gl & p \\
\hline \hline \multirow{2}{*}{ HOXA10 } & Fase & 0,88 & 1 & 0,349 \\
& Local & 0,36 & 1 & 0,549 \\
& Fase x Local & 0,01 & 1 & 0,927 \\
ER- $\beta$ & Fase & 0,01 & 1 & 0,918 \\
& Local & 2,20 & 1 & 0,138 \\
& Fase x Local & 0,23 & 1 & 0,634 \\
PR-AB & Fase & 2,82 & 1 & 0,093 \\
& Local & 1,95 & 1 & 0,162 \\
& Fase x Local & 1,17 & 1 & 0,279 \\
PR-B & Fase & 1,22 & 1 & 0,269 \\
& Local & 12,14 & 1 & $<0,001$ \\
\hline
\end{tabular}

Fase: fases proliferativa e secretora do ciclo menstrual; local: lesão e tecido muscular liso perilesional de endometriose do reto-sigmoide; fase x local: interação fase versus local; gl: grau de liberdade; P: probabilidade do resultado ser devido ao acaso

A análise revelou que a proteína PR-B apresentou diferença média de expressão estatisticamente significativa entre LES e TMLP, independentemente da fase do ciclo menstrual.

A Tabela 6 demonstra o resultado da comparação múltipla de Bonferroni realizada para a expressão da proteína PR-B em LES e TMLP de ERS. 
Tabela 6. Comparação múltipla da expressão imunoistoquímica da proteína PR-B avaliada por análise morfométrica, segundo a expressão na lesão e no tecido perilesional de endometriose do reto-sigmoide

\begin{tabular}{cccccc}
\hline Comparação & $\begin{array}{c}\text { Diferença média } \\
\text { estimada }\end{array}$ & $\begin{array}{c}\text { Erro } \\
\text { Padrão }\end{array}$ & $\mathbf{p}$ & \multicolumn{2}{c}{ IC (95\%) } \\
\cline { 5 - 7 } & $-2,00$ & & Inferior & Superior \\
\hline \hline Lesão x Perilesional & & 0,60 & $\mathbf{0 , 0 0 1}$ & $-3,18$ & $-0,81$ \\
\hline
\end{tabular}

P: probabilidade do resultado ser devido ao acaso; IC: intervalo de confiança

De acordo com a comparação, a expressão média da proteína PR-B foi estatisticamente maior no TMLP da ERS, independentemente da fase do ciclo menstrual.

A Tabela 7 descreve as correlações diretas e inversas entre as proteínas HOXA10, ER-ß, PR-AB e PR-B, e as probabilidades de essas correlações serem devidas ao acaso (valor de $\mathrm{P}$ ), segundo a AM. Novamente, as correlações foram estabelecidas de maneira geral, independentemente da fase do ciclo ou local de expressão destas na ERS.

Tabela 7. Correlações entre as expressões imunoistoquímicas das proteínas HOXA10, ER-ß, PR-AB e PR-B segundo análise morfométrica em endometriose de reto-sigmoide

\begin{tabular}{lc|ccc}
\hline Correlação & & HOXA10 & ER- $\beta$ & PR-AB \\
\hline \hline ER- $\beta$ & $\mathrm{r}$ & $-0,042$ & & \\
& $\mathrm{p}$ & 0,649 & & \\
& $\mathrm{~N}$ & 118 & & \\
PR-AB & $\mathrm{r}$ & 0,231 & $-0,050$ & \\
& $\mathrm{p}$ & $\mathbf{0 , 0 0 6}$ & 0,586 & \\
& $\mathrm{~N}$ & 143 & 119 & \\
PR-B & $\mathrm{r}$ & 0,558 & $-0,119$ & 0,558 \\
& $\mathrm{p}$ & $<\mathbf{0 , 0 0 1}$ & 0,201 & $<\mathbf{0 , 0 0 1}$ \\
& $\mathrm{N}$ & 144 & 117 & 144 \\
\hline
\end{tabular}

r: estimativa da correlação; P: probabilidade do resultado ser devido ao acaso; N: número de amostras avaliadas 
Houve correlação direta entre as expressões das proteínas HOXA10 e PR-B $(r=0,220 ; P=0,008)$ e entre HOXA10 e PR-AB $(r=0,231 ; P=$ 0,006), além da correlação direta entre PR-AB e PR-B ( $r=0,558 ; P<0,001)$.

Não houve correlação da expressão da proteína ER-ß com HOXA10, PR-AB ou PR-B.

As Figuras 7 a 10 resumem as expressões das proteínas HOXA10, ER-a, ER-ß, PR-AB, PR-B na LES e no TMLP da ERS, tomando-se a fase secretora do ciclo menstrual como exemplo. 


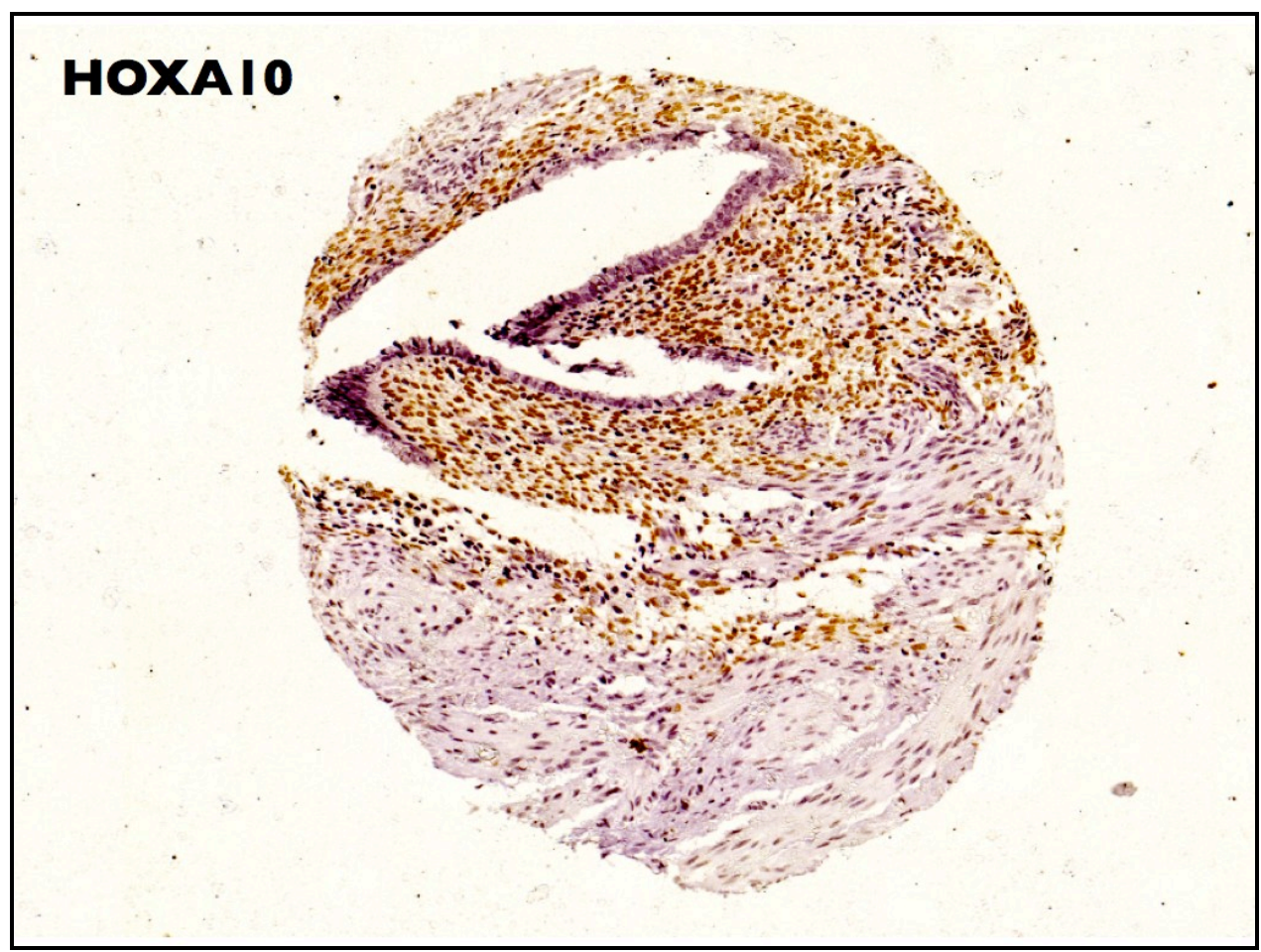

Figura 7. Expressão da proteína HOXA10 em lesão de endometriose de reto-sigmoide. A expressão é restrita aos núcleos de células do estroma endometrial

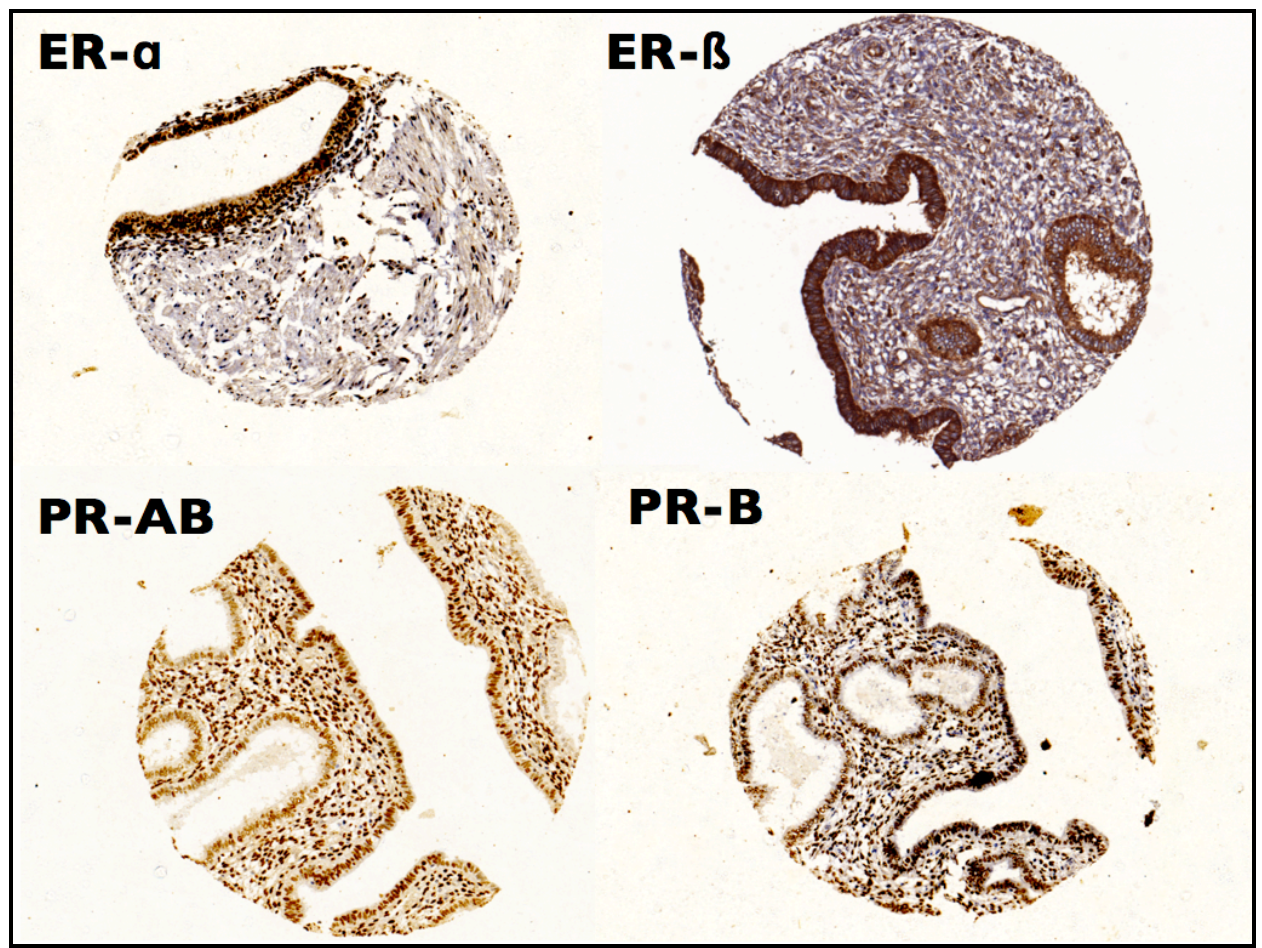

Figura 8. Expressão das proteínas ER- $\alpha$, ER- $\beta$, PR-AB e PR-B em lesão de endometriose de reto-sigmoide. Todas as proteínas são expressas nas glândulas e estroma endometriais, e restritas aos núcleos das células 


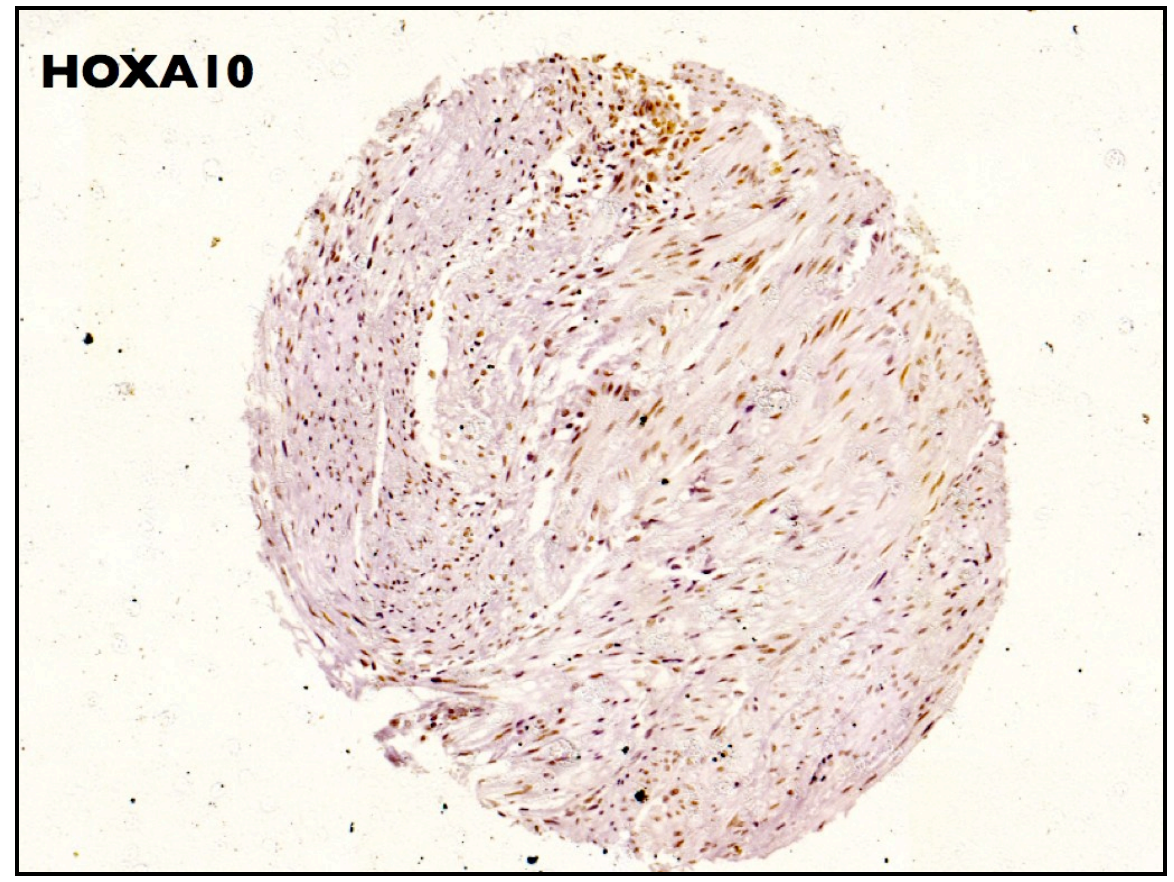

Figura 9. Expressão da proteína HOXA10 em tecido muscular liso perilesional de endometriose de reto-sigmoide. A expressão é positiva fraca e mais evidente nos núcleos de células do estroma endometrial entremeadas no tecido muscular liso

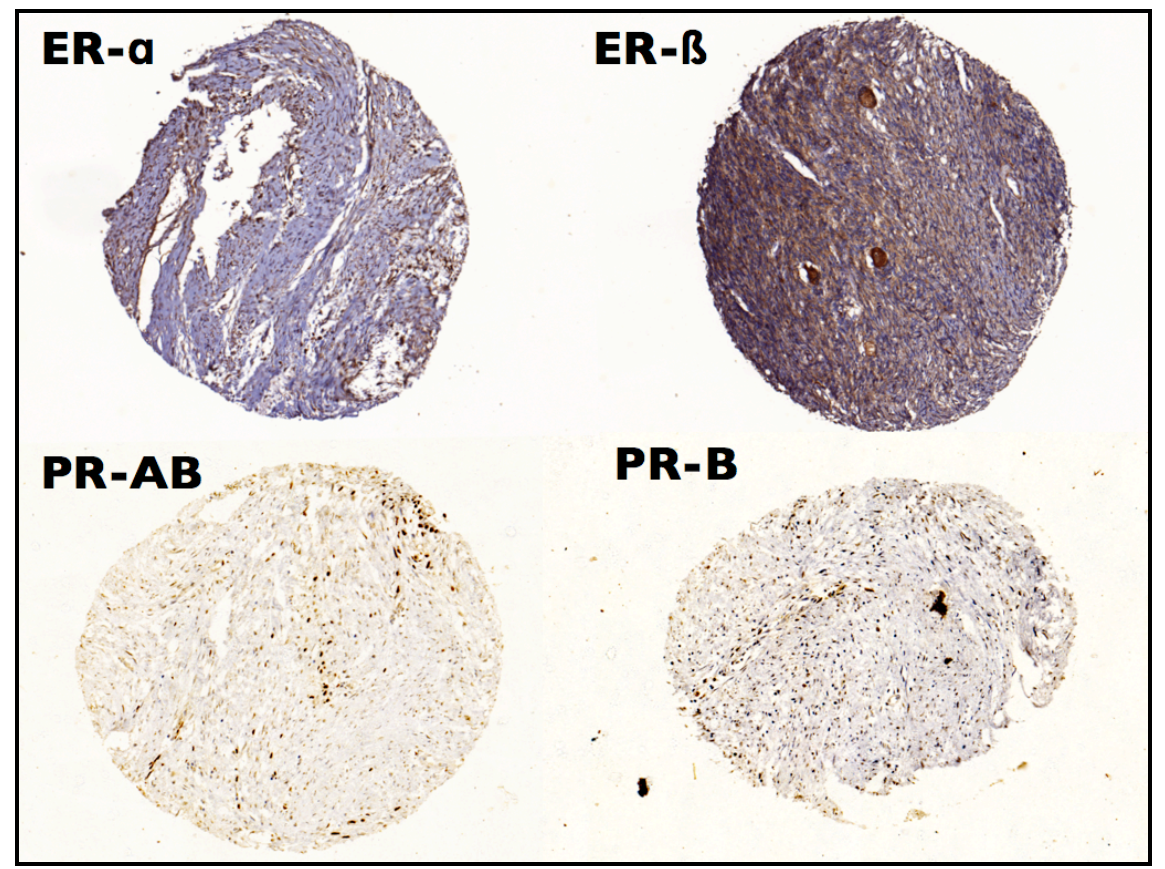

Figura 10. Expressão das proteínas ER-a, ER-ß, PR-AB e PR-B em tecido muscular liso perilesional de endometriose de reto-sigmoide. Há escassez de glândulas e estroma e predominância de tecido muscular liso. As proteínas ER- $\alpha$ e ER-ß são expressas no estroma e tecido muscular liso, enquanto as proteínas PR-AB e PR-B têm expressões positivas fracas e restritas às células estromais entremeadas no tecido muscular liso 


\subsection{Considerações Específicas}

\subsubsection{Caracterização da Casuística}

De acordo com o nosso conhecimento, nosso estudo foi o primeiro a avaliar simultaneamente a expressão das proteínas HOXA10, ER-a, ER-ß, PR-AB e PR-B em um mesmo tipo de lesão de endometriose. Isso nos permitiu determinar não apenas as suas expressões, mas também as correlações entre si, uma vez que o estradiol e a progesterona regulam a ativação de HOXA10.

O tecido muscular liso é o principal componente da EPF, e não glândulas ou estroma ${ }^{105}$. Em nosso estudo, pensamos inicialmente em interpretar as amostras dicotomicamente como sendo provenientes do núcleo da lesão que contém glândulas e estroma ou do tecido muscular perilesional que contém fibrose e músculo liso, segundo a separação nos blocos de parafina.

Porém, a técnica de TMA prevê múltiplos cortes dos blocos em várias profundidades. Assim, houve a perda da individualização compartimental que era inicialmente observada nos blocos originais de parafina.

Dessa forma, encontramos tecidos glandular e estromal entremeados em músculo liso nos spots perilesionais, e a eles limitamos nossas análises. Portanto, apesar de denominarmos as amostras como provenientes de TMLP, nossos achados não podem ser generalizados ao tecido muscular liso propriamente dito, devido à realização do TMA. 
A maior experiência e aplicação da técnica de TMA é no estudo da expressão proteica em câncer ${ }^{100-102}$. A construção de blocos de TMA com amostras de vários pacientes permite o estudo simultâneo de múltiplas proteínas de forma semiautomatizada.

Em nosso estudo, foi possível estudarmos cinco proteínas em 285 amostras provenientes de 18 pacientes com endometriose. Obtivemos amostras representativas de ao menos 15 das 18 pacientes em cada uma das análises, e cada paciente contribuiu com amostras para pelo menos uma dessas. Assim, a representatividade amostral foi satisfatória.

Entretanto, devemos considerar que o TMA nos fornece uma impressão sobre a expressão proteica em determinado momento. É como uma "fotografia" daquele instante, e que pode eventualmente não representar a atividade dos genes de interesse em outros momentos.

Além disso, há uma diferença entre a ativação de um gene e a sua expressão proteica propriamente dita. Certamente, quando estudamos proteínas, subentendemos que estamos estudando os seus respectivos genes, porém devemos entender essa limitação.

Não encontramos estudos de TMA que tenham avaliado o fator HOXA10 em endometriose. Além disso, encontramos apenas três pesquisas que utilizaram TMA para avaliação de ER e PR-AB na doença ${ }^{67,68,106}$.

Apesar da pouca experiência relatada, a técnica de TMA pode ser considerada validada para o estudo da endometriose. Mesmo avaliando pequenas lesões peritoneais, Kamat et al. ${ }^{106}$ obtiveram amostras de endometriose em $100 \%$ dos cortes, com uma perda tecidual de apenas $6 \%$. 
Os pesquisadores puderam observar uma correlação positiva entre as expressões de ER- $\alpha$ e PR-AB na endometriose e no endométrio tópico, validando o seu uso.

Por outro lado, nossa pesquisa foi a primeira a utilizar a AM para avaliar a expressão proteica de HOXA10, ER-ß, PR-AB e PR-B em endometriose. O método já foi validado para o estudo dos receptores em câncer de mama ${ }^{107}$, mas carece de validação para a avaliação de endometriose. Acreditamos que nossos dados possam servir de base para futuros estudos de validação do método também para a endometriose.

A AM nos permite estimarmos a frequência da expressão da proteína, e não a sua intensidade, como determinado à MO. Acreditamos que este tenha sido o motivo pelo qual tivemos alguns resultados divergentes entre as duas metodologias de análise.

Ainda que não tenha sido possível estimarmos o grau de expressão proteica pela AM, nossos resultados foram importantes por determinar a presença das proteínas em si, e pelas correlações entre elas.

Há muito o que se entender sobre a origem e a perpetuação da EPF. Possivelmente, os principais mecanismos a serem elucidados são aqueles que causam proliferação, metaplasia e diferenciação celular. Dessa forma, consideradas as possibilidades do estudo simultâneo de várias proteínas envolvidas nestes processos, e da amostragem tecidual de múltiplos pacientes, consideramos a técnica de TMA uma opção promissora para novos estudos sobre endometriose. 


\subsubsection{Considerações sobre o fator de transcrição HOXA10}

Este foi o primeiro estudo que avaliou a expressão proteica de HOXA10 em ERS. Demonstramos que a proteína teve uma expressão positiva fraca, principalmente no estroma de células de LES durante a fase secretora do ciclo menstrual, de acordo com a análise por MO. Já na AM, encontramos uma expressão média em 1-3\% das ATS em LES e TMLP e durante ambas as fases, um resultado que necessita de validação devido ao método ser inovador.

Nossos resultados estão de acordo com a presença de HOXA10 em outros tipos de lesão de endometriose: EPT, EOV, retovaginal e pulmonar ${ }^{15}$, 46. Mesmo que fraca, a expressão de HOXA10 fora de seu domínio espacial, dito endométrio e miométrio, é muito importante. Isso reforça a hipótese de que o gene seja necessário para conferir a identidade "de novo" à endometriose. A presença de HOXA10 em vários tipos de lesões de endometriose condiz com a sua função de conferir identidade de endométrio e promover a diferenciação tecidual.

O gene HOXA10 foi demonstrado no cólon distal de camundongos, naquele que foi o estudo primordial que estabeleceu o padrão de expressão espacial e temporal dos HOX genes no trato genital feminino ${ }^{36}$. Esse achado é bastante significativo, porque o gene HOXA10 não está envolvido na embriogênese do reto-sigmoide ou de qualquer outra porção do trato gastrointestinal $^{108}$. 
Infelizmente, não foram realizados outros estudos para investigar esse achado. Seria importante pesquisar se o gene HOXA10 e a sua proteína estariam expressos nas porções sadias do reto-sigmoide de adultos, ou se apenas naqueles locais que têm a identidade tecidual de endometriose. Esta é uma questão importante porque os HOX genes têm uma expressão espacial altamente ordenada e com limites de expressão bem definidos.

Assim como os HOX genes, as lesões de endometriose intestinal têm uma distribuição espacial altamente ordenada. Elas estão presentes apenas no reto-sigmoide, no íleo terminal, apêndice e ceco. Não há endometriose de cólon ascendente, transverso, ou descendente. Não há endometriose de jejuno, duodeno, ou porções proximais do íleo. As lesões seguem uma distribuição espacial ordenada, o que sugere que HOXA10 possa ter papel nessa distribuição.

Por último, a expressão da proteína esteve restrita ao estroma da LES de ERS. Esse achado está de acordo com o único estudo que avaliou a expressão do gene em EPF, porém em lesão retovaginal ${ }^{46}$. Em EPT e EOV, HOXA10 também teve uma maior expressão no estroma das lesões em comparação ao epitélio, apesar de estas não serem um modelo ideal para comparação $^{15}$.

Os HOX genes são expressos em diferentes populações de célulastronco estromais. Isso pode ser observado na medula óssea, polpa dentária, e no trato gastrointestinal, onde os HOX genes regulam a diferenciação das 
células estromais em células mais diferenciadas ${ }^{39}$. É possível que essa ação ocorra também na EPF.

Outra hipótese para explicar a expressão estromal de HOXA10 relaciona-se ao período embrionário. Durante a embriogênese do trato genital feminino, o gene HOXA10 segue um padrão de expressão temporal definido entre o epitélio e estroma endometriais. Inicialmente, o gene tem uma forte expressão no epitélio, passando depois a ser expresso apenas no estroma ${ }^{42}$.

Propomos que a fraca expressão de HOXA10 em células estromais de EPF poderia mimetizar o mesmo padrão de expressão observado no útero embrionário. Células epiteliais glandulares de EPF, por serem mais diferenciadas que células estromais, já não expressariam mais a proteína (ou a expressariam fracamente), talvez desde o seu surgimento.

Certamente, o gene HOXA10 é um importante candidato para a investigação da fisiopatologia da EPF. Há apenas um estudo sobre a sua presença nesse tipo de lesão ${ }^{46}$, e nosso trabalho é o primeiro a descrevê-lo em ERS. O próximo passo poderia ser a realização de estudos que avaliassem a sua presença durante a embriogênese, em endometriose de fetos, e que possam desvendar mecanismos adicionais envolvidos na conferência de identidade de endométrio a tecidos indiferenciados. 


\subsubsection{Considerações sobre os receptores de estrogênio}

O nosso estudo soma-se aos poucos que reportaram dados da expressão das duas isoformas do ER em lesões de EPF de forma separada $28,67,68$. Pudemos ainda avaliar, pela primeira vez, o comportamento na EPF de ER- $\alpha$ e ER-ß em relação a HOXA10, PR-AB e PR-B, sabidamente envolvidos na patogênese da endometriose.

Encontramos uma forte expressão de ER-a em ERS, durante ambas as fases do ciclo menstrual. Sua forte expressão nesse tipo de lesão de EPF esteve de acordo com o único estudo que o avaliou separadamente em outras lesões de $\mathrm{EPF}^{68}$. Esse achado reforça a hipótese de que EPF e EOV são doenças distintas, pois nesta o ER-a é expresso em baixos níveis ${ }^{13,17}$, 63

Da mesma forma, a expressão de ER-ß em ERS também está de acordo com a sua expressão em EPF observada neste mesmo estudo ${ }^{68}$. A importância de ER-ß é tamanha, que ele é objeto de pesquisas sobre moduladores para o tratamento não apenas da endometriose ${ }^{62,65}$, mas também da artrite reumatoide, de alguns tipos de câncer, e de doenças do sistema nervoso central $^{109,110}$.

Supostamente, a resistência clínica da endometriose à progesterona seria devida à redução de $\mathrm{PR}-\mathrm{AB}$ e $\mathrm{PR}-\mathrm{B}$, que por sua vez seriam causadas por uma deficiência na metilação e aumento da expressão de ER- $\aleph^{47}$. Um aumento proporcional da expressão de ER-ß em relação a ER- $\alpha$ também 
contribuiria para a resistência à progesterona. Essa relação foi demonstrada com estudo dos receptores nas lesões de EOV ${ }^{61,63}$.

Porém, nossos achados em lesões de EPF foram divergentes desses estudos. Além de demonstrarmos uma forte expressão de PR-AB e PR-B nas lesões, não pudemos demonstrar uma relação inversa entre estes e ERß.

Não avaliamos a relação entre ER-a e ER-ß na EPF, pois os estudamos por metodologias diferentes. Já Samartzis et al. ${ }^{68}$ demonstraram que ER-a e ER-ß tiveram forte e média expressão em EPF, respectivamente, e que ER- $\alpha$ não apresenta diminuição de expressão neste tipo de lesão. De fato, ER-a teve expressão até mais evidente do que ER-ß nesse estudo que também utilizou TMA para avaliar lesões de EPF.

Os estudos sobre moduladores de ER-ß em endometriose são experimentais, feitos com a indução de EPT em murinos. Nestes, houve uma regressão parcial ou total das lesões em uma proporção variável das cobaias $^{62,65}$. Porém, ainda não há ensaios clínicos com as drogas, tampouco em EPF, que possam confirmar sua aplicação clínica no tratamento da doença. Nossos achados sugerem que no ambiente específico da EPF, a ação dos moduladores de ER-ß possa ser diferente e mereça ser estudada individualmente.

Outro achado importante diz respeito à possível regulação do gene HOXA10 pelo estradiol nas lesões de EPF. Essa ação ocorre no epitélio e estroma endometriais, tanto in vitro como in vivo ${ }^{41}$. Nestes, há um aumento linear da expressão do gene durante o ciclo menstrual em resposta à ação 
do estradiol, que é suprimido pela anovulação e pelo uso do análogo de gonadotrofina humana ${ }^{41}$. Não se sabe se essa regulação ocorreria também no ambiente específico da EPF.

Em nosso estudo, não houve correlação entre ER-ß e HOXA10 segundo dados da AM. Não foi possível calcularmos a correlação entre ER- $\alpha$ e HOXA10 devido ao baixo número de amostras na análise por MO.

Uma hipótese para esse achado seria a presença de diferenças epigenéticas entre os genes HOXA10 ativos no endométrio tópico e na EPF. Eventualmente, as regiões promotoras do gene HOXA10 que contêm ERE-1 seriam diferentes nos dos ambientes, e responderiam de forma distinta ao estradiol.

Entretanto, não é possível afastarmos a hipótese de que exista de fato uma regulação direta do estradiol sobre a expressão de HOXA10 em EPF, talvez mediada por ER-a. Essa seria uma regulação esperada, considerando a ação mitógena do hormônio sobre a doença e a sua ação no período embrionário. Novos estudos com um número maior de amostras poderiam avaliar essa hipótese.

\subsubsection{Considerações sobre os receptores de progesterona}

Os nossos achados sobre PR-AB e PR-B em EPF são originais, pois pela primeira vez eles foram estudados nesta lesão em relação a outros importantes agentes implicados na doença: HOXA10, ER-a e ER-ß. 
Primeiro, encontramos uma forte expressão de PR-AB e PR-B em glândulas e estroma de LES de EPF, durante as fases proliferativa e secretora do ciclo menstrual. Segundo, PR-B foi mais expresso durante a fase secretora, de acordo com a análise por MO. Terceiro, demonstramos uma correlação positiva entre as proteínas PR-AB e PR-B com HOXA10, de acordo com a AM.

Nosso estudo foi o primeiro a avaliar a expressão da isoforma PR-B em EPF. Contrariamente a estudos realizados com EPT e EOV ${ }^{14,}{ }^{16}$, encontramos uma forte expressão de PR-B nesse tipo de lesão.

Entendemos que esta seja mais uma evidência de que as doenças são diferentes, e por isso as conclusões a respeito da endometriose devam ser individualizadas. A forte expressão de PR-B reforça o papel da progesterona na fisiopatologia da doença, já que esta é a isoforma mais potente na ativação de resposta tecidual.

Contudo, não podemos afastar a possibilidade de que a discrepância entre nosso estudo e os demais possa ter ocorrido pelo uso de diferentes técnicas laboratoriais, e não apenas pelo estudo de diferentes lesões. Pesquisas anteriores utilizaram uma combinação de reação de polimerase em cadeia, microcaptura a laser e Western blot para detectarem o RNAm dos receptores esteroidais ${ }^{14,16}$, enquanto nós utilizamos imunoistoquímica precedida de TMA para detectar suas expressões proteicas.

Por outro lado, observamos correlações positivas entre as expressões de PR-AB e PR-B, nos dois métodos de análise. Sabendo-se que PR-AB já 
foi demonstrado em EPF ${ }^{67,68,82}$, essas correlações sustentam a validade do achado de que PR-B realmente tenha uma forte expressão na EPF.

Além disso, a presença de PR-AB e ER em EPF está de acordo com a única pesquisa que também utilizou a técnica de TMA para estudá-los em lesões de $\mathrm{EPF}^{67}$. Novamente, esses achados sustentam a expressão de PR$B$ na EPF.

Demonstramos ainda que PR-B esteve mais expresso na EPF durante a fase secretora do ciclo menstrual, e que HOXA10 também esteve expresso principalmente durante a fase secretora. Esses dados reforçam uma possível ação da progesterona sobre a ativação de HOXA10 na EPF, talvez mediada por PR-B.

A progesterona exerce a função de diferenciação das glândulas endometriais mediada pela ativação do fator HOXA10, tanto in vitro como in vivo $^{41,84}$. Portanto, a relação direta que observamos entre PR-AB e PR-B com HOXA10 foi um achado bastante significativo. Observamos esta relação à $\mathrm{AM}$, que não se confirmou à $\mathrm{MO}$, possivelmente devido ao pequeno número de amostras positivas para HOXA10 nesta análise.

Assim, nossos resultados sugerem pela primeira vez que a progesterona possa regular a expressão de HOXA10 na EPF. Supostamente, a presença de HOXA10 seria necessária para que a progesterona pudesse conferir, ao menos em parte, a identidade tecidual de endometriose a um tecido indiferenciado. A fraca expressão de HOXA10 também se correlacionaria com o achado histológico de poucas glândulas e estroma que são observados na EPF. 
Em relação ao TMLP, nossos resultados sobre a expressão de PR-AB e PR-B foram divergentes entre as duas análises. Pudemos demonstrá-los à AM, porém não os detectamos à MO.

Há uma hipótese que pode explicar essa divergência. Conforme mencionado, não foi possível individualizarmos glândulas, estroma, fibrose e tecido muscular liso nos spots de TMLP durante a AM. É possível que o software tenha detectado as marcações de glândulas e estroma entremeados no músculo liso dos spots de TMLP, e não no músculo liso em si. Por isso, nossas conclusões relacionadas às expressões das proteínas no TMLP devem ser limitadas.

Ainda assim, vale a menção de que PR-AB já foi demonstrado no TMLP de EPF $27,28,67,82$, incluindo $\mathrm{ERS}^{28,67}$. Segundo os pesquisadores, o achado de PR-AB (e também de ER) no TMLP da EPF sugere que o estradiol e a progesterona possam ter um papel na gênese das glândulas e na metaplasia muscular lisa observada nessas lesões, por mecanismos parácrinos ainda a serem esclarecidos ${ }^{28,82}$. Concordamos que esta é uma hipótese plausível que mereça ser mais bem estudada.

Por último, observamos uma relação inversa entre PR-AB e ER-a nas glândulas e estroma da EPF. Isso nos faz supor que ela tenha ocorrido devido à presença da isoforma PR-A na lesão, detectada pelo anticorpo PR$\mathrm{AB}$.

Essa hipótese estaria de acordo com estudos in vitro que mostram que PR-A é um repressor da transcrição de ER- $\alpha$, PR-B e de outros 
receptores esteroidais ${ }^{78,80}$. Lembramos, porém, que nossos resultados não permitem conclusões sobre a expressão diferencial de PR-A na EPF.

Em resumo, a forte expressão de PR-AB e PR-B e a sua relação com HOXA10 em EPF avalizam o papel da progesterona na doença. Poderão ser esclarecedores os estudos futuros que avaliem melhor o papel da isoforma PR-B na EPF, além da relação da progesterona com HOXA10 e fatores de crescimento envolvidos na metaplasia e hiperplasia muscular lisa tipicamente observadas na EPF.

\subsection{Considerações Finais}

As semelhanças entre o tecido endometrial tópico e ectópico se resumem à histologia. Do ponto de vista molecular e funcional, são essencialmente diferentes $^{13,111-114}$. Ainda assim, as conclusões sobre a fisiopatologia da endometriose costumam ser baseadas em comparações realizadas entre o endométrio tópico e as lesões de endometriose de uma mesma paciente, ou entre o endométrio tópico de pacientes que tenham ou não endometriose ${ }^{13,17,18,114-118}$. Parte-se da premissa de que a EPF seja causada por refluxo menstrual.

Outro importante fator de confusão é a interpretação de que EPT, EOV e EPF tenham a mesma fisiopatologia ${ }^{12,16,63,64,66}$. A EPT é superficial, altamente vascularizada e funcionalmente mais ativa ${ }^{5}$. Segundo Evers ${ }^{119}$, "a endometriose peritoneal não existe: todas as mulheres têm endometriose". 
Tamanha seria a probabilidade de se diagnosticar EPT em mulheres que ela poderia ser considerada um epifenômeno ${ }^{119,120}$.

Por outro lado, a EPF é retroperitoneal, com abundante metaplasia muscular lisa e tecido fibroso adjacentes a escassas glândulas e estroma endometriais $^{1}$. Já as lesões de EOV são pseudocistos com acúmulo de debris menstruais ${ }^{121}$ e invariavelmente associadas a EPF ${ }^{122,123}$, sendo nada mais que uma consequência desta. São três doenças distintas, cuja única semelhança entre si é a presença de glândula e/ou estroma endometrial.

Segundo Sampson ${ }^{124}$ e senso comum vigente, a EPF é consequência da evolução "mais profunda" da EPT, que por sua vez seria causada por menstruação retrógrada ${ }^{125-127}$. Segundo Cullen $^{128}$, e defendido por alguns pesquisadores, a EPF é consequência da metaplasia de restos Müllerianos existentes no retroperitônio ${ }^{129,130}$.

Indiscutivelmente, a teoria mais aceita na Medicina moderna para explicar a origem da EPF é aquela da menstruação retrógrada.

Indiscutivelmente, nenhuma medicação que cause bloqueio hormonal ou supressão dos ciclos menstruais foi capaz de erradicar a EPF. Servem ao controle, mas não ao tratamento (erradicação) da doença.

Indiscutivelmente, não houve progressos reais no tratamento clínico da endometriose desde a publicação da teoria há 86 anos ${ }^{124}$ pois, em última análise, continuamos tratando-a da mesma forma que Thomas Cullen o fazia no início do século passado: pela excisão cirúrgica. 
Este é o grande desafio da Medicina moderna: explicar a fisiopatologia da EPF. Certamente, os avanços reais que tanto desejamos ocorrerão após ela ser completamente compreendida.

Felizmente, surgem novas evidências que podem trazer avanços à compreensão da doença. Trabalhos atuais demonstram a existência de endometriose em fetos ${ }^{94-96}$, e outros sugerem que as alterações observadas no endométrio tópico de pacientes com a doença possam ser consequência da doença, e não a sua causa ${ }^{131-133}$.

Em camundongos e babuínos, a endometriose experimental é capaz de produzir metilação e alteração da expressão de genes no endométrio tópico, incluindo HOXA10 ${ }^{131-133}$. Além de uma redução gradual da expressão do gene HOXA10 (similar ao observado em mulheres com endometriose) ${ }^{131}$, a endometriose experimental poderia promover um perfil de expressão gênica endometrial que inicialmente é estrogênico, passando depois a um perfil de resistência à progesterona ${ }^{133}$.

São dados experimentais, é fato. Porém, sugerem que as alterações endometriais comumente observadas nas pacientes com endometriose (e amplamente difundidas como explicação para a sua origem) possam ser simplesmente uma consequência, e não a sua causa.

E o que dizer de endometriose em fetos? Há quatro anos, Signorile et al. ${ }^{94}$ demonstraram a presença de glândulas endometriais em localização ectópica na pelve de fetos femininos, em um período tão precoce quanto 14 semanas de gestação. Há um ano, os autores completaram uma série de 
101 fetos estudados, e demonstraram a ectopia em nove deles $(9 \%)^{95}$. Essa é a prevalência aproximada da endometriose em mulheres adultas.

Além disso, os locais de ectopia são extremamente semelhantes àqueles onde são observadas as lesões de EPF na mulher adulta: espaço retovaginal, região retrocervical, e reto-sigmoide.

Bouquet de Joliniere et al. ${ }^{96}$ são os primeiros a confirmarem os achados daqueles pesquisadores. Em publicação há seis meses, os autores relatam a presença de glândulas e ductos embrionários ricamente circundados por células estromais no ligamento largo e serosa tubárea de seis entre sete fetos estudados. Essas células expressavam PR, ER- $\alpha$ e eram positivas para CD10, um marcador de células estromais endometriais.

São amostras pequenas, dados iniciais, mas que são, no mínimo, passíveis de citação de destaque e ampla discussão.

O objetivo do nosso estudo foi trazer uma contribuição ao entendimento da EPF, mesmo que com uma pequena amostra. Para isso, optamos por estudar a expressão proteica de um gene de enorme importância na embriogênese do trato genital e na diferenciação celular endometrial. Estudamos também a expressão proteica dos receptores dos dois principais hormônios envolvidos em sua patogênese: o estradiol e a progesterona.

Além disso, optamos por estudar um modelo representativo de EPF, e limitamos nossas conclusões apenas à EPF. Tentamos evitar comparações com EPT, EOV e com o endométrio tópico, por mais que tenham sido inevitáveis em alguns momentos. 
Certamente, nossos resultados não nos permitem concluir que a EPF tenha origem embrionária. Ainda assim, propomos um modelo que poderia explicar o papel do gene HOXA10 em sua etiologia (Figura 11).

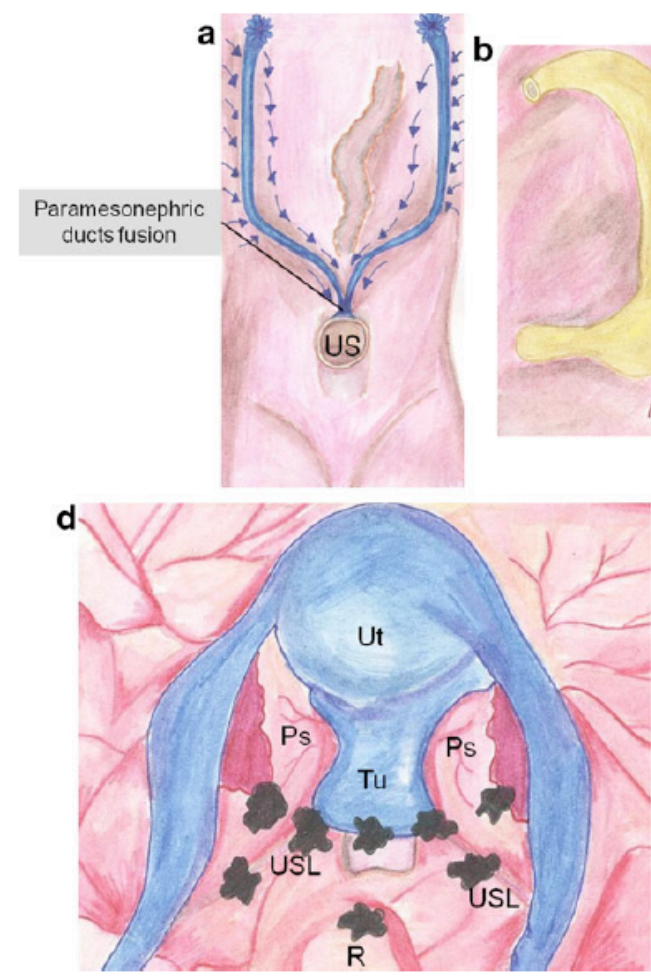

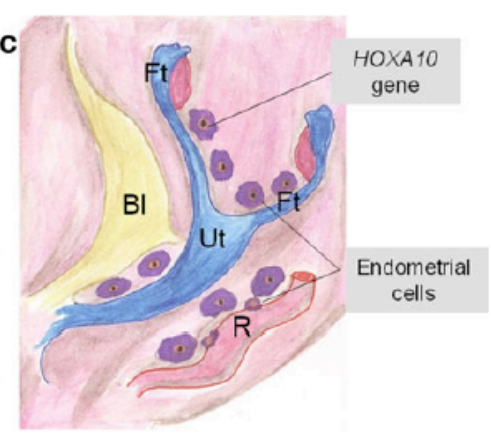

$\mathrm{BI}$
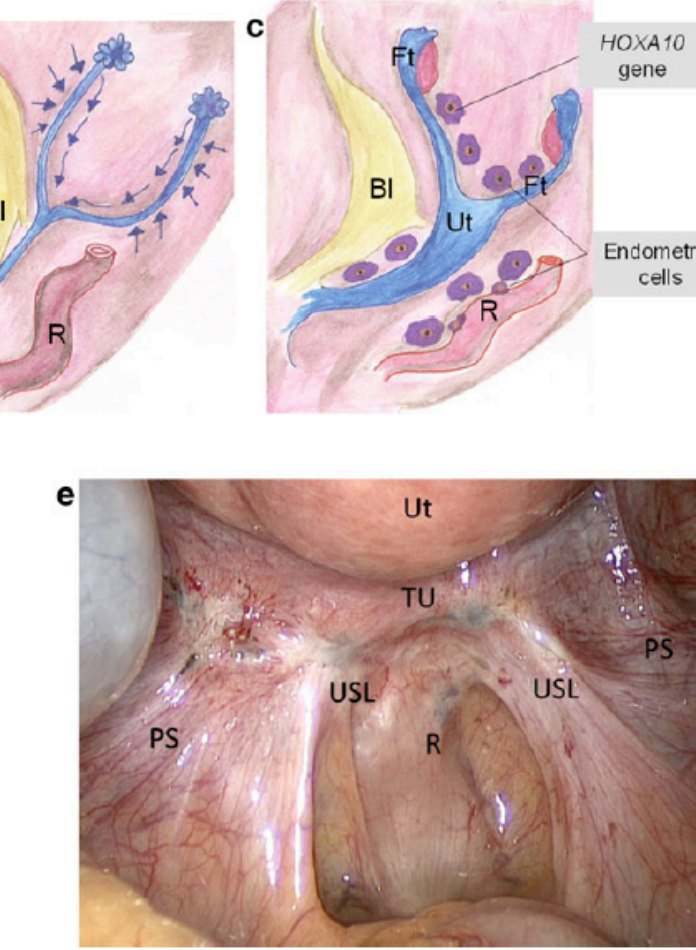

FONTE: Zanatta, $2010^{45}$

Figura 11. Embriogênese do trato genital feminino e papel proposto do gene HOXA10 na etiologia da endometriose. Perspectivas (a) coronal e (b) paramediana do embrião humano feminino com seis semanas de gestação. Pregas longitudinais de células mesenquimais invaginam-se a partir das paredes abdominais laterais para formarem cordões que crescem caudalmente e se fundem na linha média (os ductos paramesonéfricos, destacados em azul), como indicado por setas pequenas. 0 gene HOXA10 irá conferir a identidade à porção do ducto destinada a ser o útero, incluindo o endométrio. (c) Possivelmente, células mesenquimais sob a influência do gene HOXA10 possam ser destinadas a se tornarem células endometriais em localizações ectópicas, incluindo o tórus uterino (TU), ligamentos útero-sacros (USL), paredes pélvicas laterais (PS), e reto-sigmoide (R), entre outros. Esses locais corresponderiam às localizações mais comuns das lesões de endometriose (marcas negras) observadas na mulher adulta $(d, e)$. UT=útero; US=seio urogenital e bexiga em desenvolvimento; $B L=$ bexiga 
O único fato novo neste modelo é a inclusão do gene HOXA10. A ideia de que a EPF poderia ser originar de "restos do ducto de Müller" data do início do século passado ${ }^{128,134,135}$, antes da publicação da teoria da menstruação retrógrada.

Para concluir, façamos uma breve analogia histórica com o estudo da evolução das espécies durante o século XIX. Hoje sabemos que Charles Darwin e Jean-Baptiste de Lamarck observaram os mesmos fatos, porém tinham conclusões opostas.

Lamarck $^{136}$ acreditava que a evolução das espécies acontecia por caracteres adquiridos. Segundo essa teoria, as transformações ocorridas no ambiente terrestre forçariam os seres que nele vivem a se transformarem para poderem sobreviver. Uma força externa que os moveria rumo à perfeição. Haveria a transmutação de espécies: novas espécies surgiriam através do acúmulo progressivo de mutações na espécie original.

Darwin $^{137}$ acreditava na evolução das espécies ao acaso, por meio da seleção natural. A evolução ocorreria pela descendência com modificação. Indivíduos dotados de vantagens teriam maior probabilidade de sobreviver e se reproduzir, enquanto aqueles em desvantagem seriam eliminados.

Darwin abandonou a Medicina por ser contrário à brutalidade das cirurgias da época. Passou, então, a desenvolver em segredo as suas teorias sobre a evolução das espécies por medo de represálias. Apesar de ter estudado Teologia, sua teoria implicava em dizer que não havia uma separação clara entre homem e animais, uma grande heresia à época. 
Após $A$ Origem das Espécies ${ }^{137}$ de Darwin, em 1859, seguiu Mendel $^{138}$, em 1866, que estabeleceu as bases da Genética moderna com o clássico experimento de ervilhas. Inicialmente interpretadas como antagônicas, as ideias de Darwin foram conciliadas às de Mendel em 1942 com a publicação de Evolução: a Síntese Moderna ${ }^{139}$. Em 1953, veio a seminal descrição da estrutura do DNA por Watson e Crick $^{140}$, e, nos dias atuais, quase todo o genoma humano está sequenciado ${ }^{141}$.

Avanços reais.

Em tempo: as ideias de Darwin sobre a seleção natural das espécies só foram completamente aceitas quase cem anos após a sua publicação. 


\section{CONCLUSÕES}


$>$ O fator de transcrição do gene homeobox A10 (HOXA10) foi expresso no estroma da lesão (LES) de endometriose do reto-sigmoide (ERS) durante a fase secretora do ciclo menstrual, segundo análise por microscopia ótica (MO). Na análise morfométrica (AM), o fator foi expresso tanto na LES como no tecido muscular liso perilesional (TMLP) durante as fases proliferativa e secretora do ciclo.

> As isoformas a (ER- $\alpha)$ e $\beta(E R-ß)$ do receptor de estrogênio foram expressas em glândulas e estroma de LES e TMLP, durante ambas as fases do ciclo menstrual, segundo avaliação por MO e AM.

O receptor de progesterona $(P R-A B)$ e a sua isoforma $B(P R-B)$ foram expressos em LES durante ambas as fases do ciclo menstrual, segundo avaliações por MO e AM.

As expressões das proteínas PR-AB e PR-B foram discordantes no TMLP. Apesar de terem sido detectadas à AM, o mesmo não ocorreu à MO.

$>$ A proteína PR-B glandular e estromal foi mais expressa em ERS durante a fase secretora do ciclo menstrual, segundo avaliação por MO.

A proteína PR-B foi mais expressa no TMLP de ERS em qualquer fase do ciclo menstrual, segundo a AM. 
Houve correlação direta entre a expressão das proteínas HOXA10 com PR-AB e PR-B na ERS, independentemente da fase do ciclo menstrual, segundo a AM.

Não houve correlação entre as expressões de ER- $\alpha$ ou ER-ß com as expressões de PR-AB, PR-B ou HOXA10, seja em ERS ou TMLP em nenhuma das fases do ciclo menstrual, segundo avaliações por MO (ERa) e $A M(E R-ß)$.

Houve correlação inversa entre as expressões de PR-AB no estroma e ER- $\alpha$ em glândulas, e entre PR-AB em glândulas e ER- $\alpha$ no estroma, na ERS durante ambas as fases do ciclo menstrual, segundo avaliação por MO. 
7 ANEXOS 
ANEXO A - Dados da análise de lesão de endometriose do reto-sigmoide por microscopia ótica

\begin{tabular}{|c|c|c|c|c|c|c|c|c|}
\hline \multirow{5}{*}{$\begin{array}{l}\text { FASE PROLIFERATIVA } \\
\text { paciente } 02\end{array}$} & HOXA10 glândula & \begin{tabular}{|l|} 
HOXA10 estroma \\
\end{tabular} & ER- $\alpha$ glândula & ER- $\alpha$ estroma & PR-AB glândula & PR-AB estroma & PR-B glândula & PR-B estroma \\
\hline & & & & & & & 12 & 6 \\
\hline & & & 12 & 9 & 9 & 9 & & \\
\hline & & & & & 3 & 12 & & 12 \\
\hline & & & & 6 & 9 & 12 & & \\
\hline paciente 05 & & & & & & 9 & & \\
\hline paciente 06 & & & 8 & 8 & 8 & 12 & 2 & 12 \\
\hline \multirow[t]{4}{*}{ paciente 07} & & & 6 & 6 & 12 & 12 & & 9 \\
\hline & & & & & 12 & 6 & 9 & 12 \\
\hline & & & & & & 9 & 0 & 12 \\
\hline & & & & & 12 & 9 & 12 & 3 \\
\hline \multirow[t]{4}{*}{ paciente 09} & & & 2 & 1 & & & & \\
\hline & & & 12 & 12 & & & & \\
\hline & & & 12 & 2 & & & & \\
\hline & & & & & 12 & 9 & 12 & 12 \\
\hline \multirow{4}{*}{ paciente 14} & & & 12 & 9 & & & & \\
\hline & & & 12 & 9 & 4 & 12 & & \\
\hline & & & & & 12 & 12 & 12 & 12 \\
\hline & & & 12 & & 12 & 9 & 12 & 9 \\
\hline \multirow[t]{5}{*}{ paciente 15} & & & 12 & 9 & 9 & 12 & & 12 \\
\hline & & & 8 & 9 & 9 & 12 & 12 & 8 \\
\hline & & & & & 3 & 12 & 0 & 6 \\
\hline & & & & 9 & 6 & 12 & 0 & 12 \\
\hline & & & 6 & 9 & 8 & 12 & & \\
\hline \multirow{3}{*}{ paciente 16} & & & & & 12 & 12 & 12 & 12 \\
\hline & & & & & 8 & 9 & & \\
\hline & & & $\begin{array}{c}6 \\
12\end{array}$ & $\begin{array}{l}4 \\
9\end{array}$ & $\begin{array}{l}12 \\
4\end{array}$ & $\begin{array}{l}12 \\
12\end{array}$ & 9 & 12 \\
\hline paciente 18 & & & 12 & 9 & 4 & 12 & 9 & 12 \\
\hline \multirow{8}{*}{$\begin{array}{l}\text { FASE SECRETORA } \\
\text { paciente 01 }\end{array}$} & HOXA10 glândula & HOXA10 estroma & ER- $\alpha$ glândula & ER- $\alpha$ estroma & PR-AB glândula & PR-AB estroma & PR-B glândula & PR-B estroma \\
\hline & & & 12 & 12 & 8 & 8 & & 12 \\
\hline & & & 12 & 12 & 8 & 8 & & 9 \\
\hline & & & 12 & 6 & 12 & 9 & 12 & 12 \\
\hline & & & 8 & 6 & 8 & 12 & 12 & 12 \\
\hline & & & 12 & 6 & 8 & 12 & 12 & 12 \\
\hline & & & 8 & 12 & 9 & 12 & & 12 \\
\hline & & & 12 & & 8 & 12 & 12 & 12 \\
\hline \multirow{20}{*}{ paciente 03} & & & & 6 & 9 & 12 & & \\
\hline & & & 12 & 9 & 12 & 12 & & \\
\hline & & & 12 & 9 & 12 & 12 & 12 & 12 \\
\hline & & 2 & & & & 12 & & \\
\hline & & & & & 9 & 12 & 12 & 12 \\
\hline & & & 8 & 12 & 8 & 12 & & \\
\hline & & & & & 8 & 12 & 12 & 12 \\
\hline & & & 6 & 6 & 3 & 12 & 12 & 12 \\
\hline & & & 3 & 3 & 12 & 12 & & \\
\hline & & & 12 & 12 & & & & \\
\hline & & & 12 & 12 & & & & \\
\hline & & & 12 & 6 & & 12 & 2 & 12 \\
\hline & & & & 0 & & 9 & & 9 \\
\hline & & & & & & 12 & & 12 \\
\hline & & & & 2 & & 12 & 12 & 12 \\
\hline & & & 8 & 9 & & & & \\
\hline & & & & & 12 & 12 & 12 & 12 \\
\hline & & & & & & 9 & 0 & 12 \\
\hline & & & 12 & 12 & & & 9 & 9 \\
\hline & & & & 0 & 12 & 6 & 12 & 9 \\
\hline \multirow[t]{3}{*}{ paciente 04} & & & & & & 6 & 12 & 12 \\
\hline & & 3 & & & 3 & & & 12 \\
\hline & & & & 6 & 3 & 12 & & 12 \\
\hline paciente 08 & & 6 & & & & 12 & & 12 \\
\hline paciente 11 & & & & & 3 & 12 & 3 & 12 \\
\hline paciente 17 & & 2 & 9 & 12 & 12 & 9 & 12 & 9 \\
\hline paciente 12 & & & 12 & 4 & 12 & 9 & & \\
\hline & & 2 & 9 & 6 & 12 & 12 & & \\
\hline & & 2 & & & 12 & 8 & 12 & 12 \\
\hline & & & 12 & 9 & 12 & 12 & 12 & 12 \\
\hline & & & & 6 & 12 & 12 & & \\
\hline & & & 8 & 4 & 12 & 12 & 12 & 12 \\
\hline & & & & & 12 & 12 & & \\
\hline paciente 10 & & & 8 & 6 & 12 & 12 & & 12 \\
\hline
\end{tabular}


ANEXO B - Dados da análise de tecido muscular liso perilesional de endometriose do reto-sigmoide por microscopia ótica

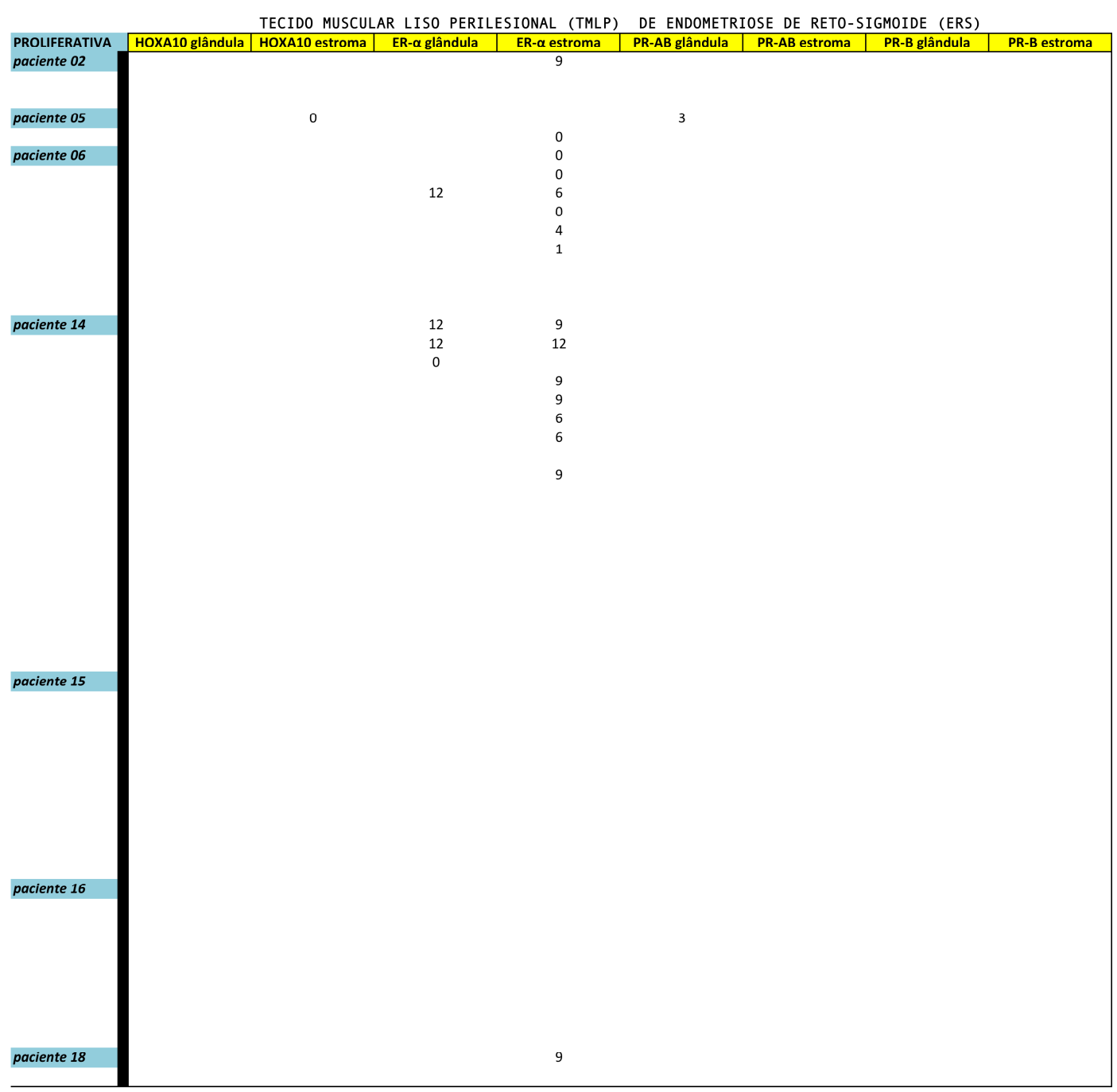




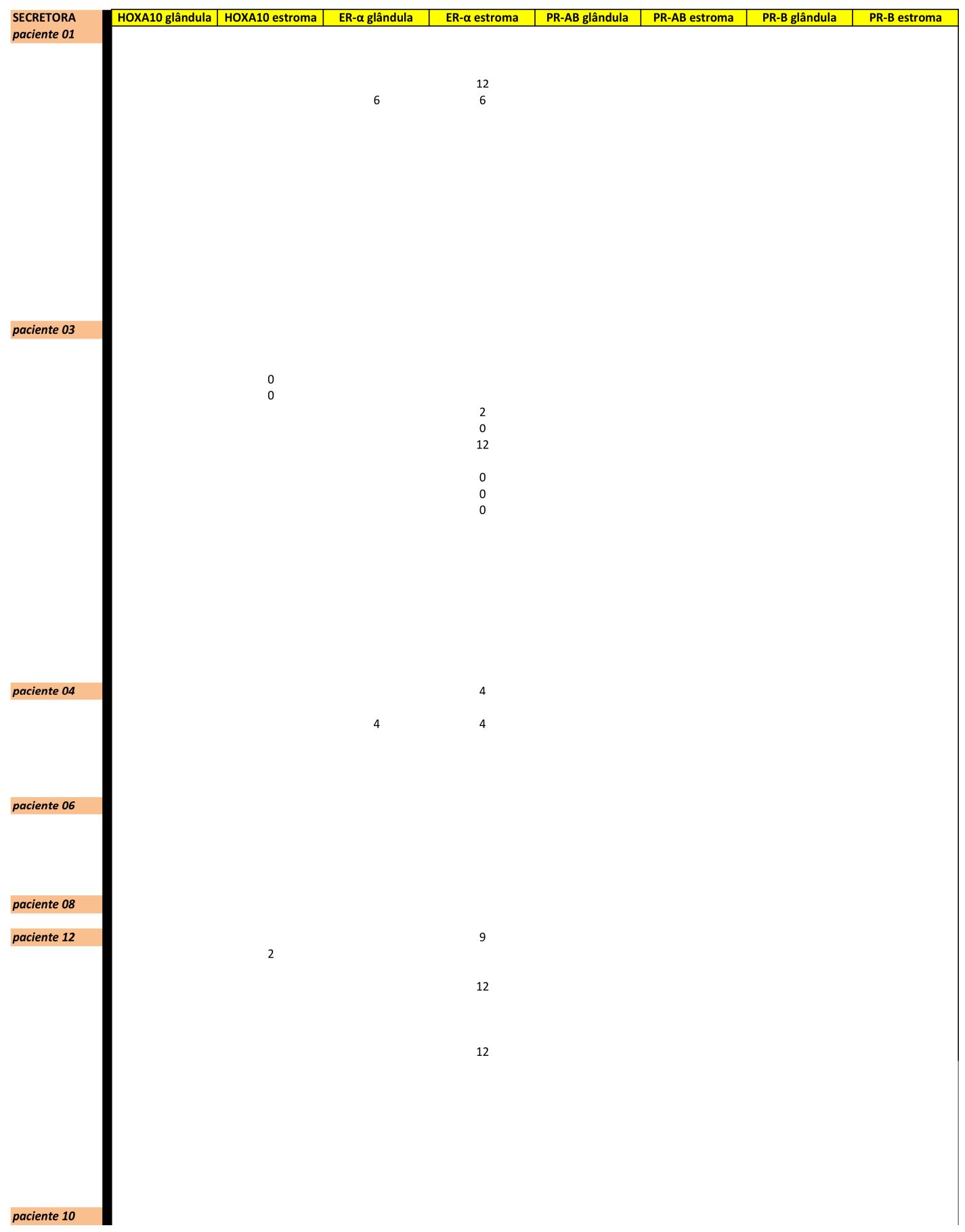


ANEXO C - Dados da análise morfométrica de endometriose do reto-sigmoide

LESÃO (LES) DE ENDOMETRIOSE DE RETO-SIGMOIDE (ERS)

\begin{tabular}{|c|c|c|c|c|}
\hline PROLIFERATIVA & HOXA10 & ER- $\boldsymbol{\beta}$ & PR-AB & PR-B \\
\hline \multirow[t]{3}{*}{ paciente 02} & 4,54E-01 & $4,78 \mathrm{E}+00$ & 5,73E-01 & $1,18 \mathrm{E}+00$ \\
\hline & 1,96E-01 & $6,64 \mathrm{E}+00$ & 1,92E-02 & 2,77E-01 \\
\hline & $1,33 E+01$ & & 3,84E-02 & $1,37 \mathrm{E}+00$ \\
\hline paciente 05 & & $3,57 E+00$ & $1,28 \mathrm{E}+00$ & $6,86 \mathrm{E}-01$ \\
\hline paciente 06 & 3,89E-01 & & $4,30 \mathrm{E}-01$ & $1,83 E+00$ \\
\hline \multirow[t]{2}{*}{ paciente 07} & 7,73E-02 & & $5,03 \mathrm{E}-02$ & $3,57 \mathrm{E}-01$ \\
\hline & & & $1,34 \mathrm{E}+00$ & \\
\hline \multirow[t]{4}{*}{ paciente 09} & $3,76 \mathrm{E}-02$ & $1,61 \mathrm{E}+01$ & 2,55E-02 & $3,40 \mathrm{E}-01$ \\
\hline & 4,97E-02 & $1,01 E+01$ & 7,27E-02 & $3,67 \mathrm{E}-01$ \\
\hline & & & $1,87 E+01$ & 4,29E-01 \\
\hline & & & 2,87E-02 & \\
\hline \multirow[t]{5}{*}{ paciente 14} & 2,51E-02 & $1,19 \mathrm{E}+01$ & 3,72E-02 & $5,49 \mathrm{E}-01$ \\
\hline & $2,12 \mathrm{E}-02$ & $9,08 E+00$ & $2,57 \mathrm{E}+00$ & 5,92E-01 \\
\hline & $1,65 \mathrm{E}-01$ & $1,27 E+01$ & $1,61 \mathrm{E}+00$ & $3,14 \mathrm{E}+00$ \\
\hline & $3,14 \mathrm{E}-02$ & $1,48 \mathrm{E}+01$ & & $1,94 \mathrm{E}+00$ \\
\hline & $1,01 E+00$ & $1,43 E+01$ & & $1,46 E+00$ \\
\hline \multirow[t]{4}{*}{ paciente 15} & $1,12 E+00$ & $8,04 \mathrm{E}+00$ & $9,22 \mathrm{E}-01$ & $1,86 \mathrm{E}+00$ \\
\hline & $6,42 \mathrm{E}-01$ & $4,90 E+00$ & $3,92 \mathrm{E}+00$ & $1,12 E+00$ \\
\hline & $2,17 \mathrm{E}+00$ & $9,49 \mathrm{E}+00$ & $1,16 \mathrm{E}+01$ & $6,91 \mathrm{E}+00$ \\
\hline & $3,80 \mathrm{E}-01$ & $6,14 \mathrm{E}+00$ & $2,22 E+00$ & $1,66 \mathrm{E}-03$ \\
\hline \multirow[t]{3}{*}{ paciente 16} & 1,97E-01 & $4,20 E+00$ & 1,42E-01 & $2,17 E+00$ \\
\hline & 5,34E-01 & $6,45 \mathrm{E}+00$ & $3,12 \mathrm{E}+00$ & $3,44 \mathrm{E}+00$ \\
\hline & & & $7,08 \mathrm{E}-01$ & \\
\hline paciente 18 & & $8,34 \mathrm{E}+00$ & $1,16 \mathrm{E}+00$ & \\
\hline
\end{tabular}




\begin{tabular}{|c|c|c|c|c|}
\hline SECRETORA & HOXA10 & ER- $\beta$ & PR-AB & PR-B \\
\hline \multirow{7}{*}{ paciente 01} & $9,15 E-01$ & $6,23 E+00$ & $2,23 \mathrm{E}-01$ & $4,29 E-01$ \\
\hline & $9,62 \mathrm{E}-01$ & $1,76 \mathrm{E}+01$ & $7,75 \mathrm{E}-01$ & $2,03 E-01$ \\
\hline & $1,59 E+00$ & $3,35 E+00$ & $4,78 \mathrm{E}+00$ & $3,98 E+00$ \\
\hline & $5,36 \mathrm{E}-01$ & $4,09 E+00$ & $8,71 \mathrm{E}-02$ & $3,20 \mathrm{E}-02$ \\
\hline & $6,41 E-01$ & $4,06 E+00$ & $2,50 \mathrm{E}+00$ & $1,81 E+00$ \\
\hline & $1,58 \mathrm{E}-01$ & & $1,70 \mathrm{E}-02$ & $9,48 \mathrm{E}-02$ \\
\hline & & & 2,61E-01 & $1,31 E+00$ \\
\hline \multirow[t]{18}{*}{ paciente 03} & $1,82 \mathrm{E}-01$ & $5,98 \mathrm{E}+00$ & $1,37 E+00$ & $7,06 \mathrm{E}-01$ \\
\hline & 1,90E-01 & $1,10 \mathrm{E}+01$ & $1,33 E+00$ & $2,98 \mathrm{E}+00$ \\
\hline & $1,85 \mathrm{E}-01$ & $5,31 E+00$ & $1,23 E+00$ & $1,22 E+00$ \\
\hline & 1,61E-01 & $8,66 E+00$ & $9,50 \mathrm{E}-03$ & $1,03 E-01$ \\
\hline & $2,88 \mathrm{E}-01$ & $1,57 E+01$ & $5,10 \mathrm{E}-01$ & $9,98 \mathrm{E}-01$ \\
\hline & $3,84 \mathrm{E}-01$ & $1,32 E+01$ & $4,16 E+00$ & $4,55 E+00$ \\
\hline & $8,24 \mathrm{E}-01$ & $2,31 E+01$ & $2,55 E+00$ & $1,15 E+00$ \\
\hline & 2,51E-01 & $1,67 E+01$ & $9,17 \mathrm{E}-01$ & $2,50 E+00$ \\
\hline & $6,45 \mathrm{E}-01$ & $1,92 E+01$ & 7,11E-01 & $1,48 E+00$ \\
\hline & $5,21 \mathrm{E}-01$ & $3,05 E+01$ & $1,41 E+00$ & $3,78 \mathrm{E}+00$ \\
\hline & $1,64 \mathrm{E}-01$ & $2,67 E+00$ & $3,97 E+00$ & 7,54E-01 \\
\hline & $4,51 \mathrm{E}-01$ & $5,63 E+00$ & 4,38E-01 & $2,07 E+00$ \\
\hline & $4,38 \mathrm{E}-01$ & $8,68 \mathrm{E}+00$ & $8,40 \mathrm{E}-01$ & $3,80 E+00$ \\
\hline & $2,21 \mathrm{E}-01$ & & $2,74 \mathrm{E}-01$ & $1,44 \mathrm{E}+00$ \\
\hline & $3,30 \mathrm{E}-01$ & & $4,41 E+00$ & $9,35 \mathrm{E}-01$ \\
\hline & $8,95 E-01$ & & $1,17 E+00$ & 7,17E-01 \\
\hline & & & 1,97E-01 & \\
\hline & & & $1,50 E+00$ & \\
\hline \multirow[t]{5}{*}{ paciente 04} & $3,19 E-01$ & $5,64 \mathrm{E}+00$ & $8,73 \mathrm{E}-01$ & $6,09 \mathrm{E}-01$ \\
\hline & $2,46 E+00$ & $3,25 E+01$ & $4,19 E+00$ & $8,56 E+00$ \\
\hline & $7,25 \mathrm{E}-01$ & $1,63 E+01$ & 5,57E-03 & $6,94 \mathrm{E}-01$ \\
\hline & $2,32 E-01$ & $5,58 \mathrm{E}+00$ & 2,55E-01 & $3,91 E+00$ \\
\hline & $9,13 E-01$ & $3,92 E+00$ & $7,68 \mathrm{E}+00$ & $4,09 E+00$ \\
\hline paciente 08 & $5,35 E+00$ & $6,51 E+00$ & $6,18 \mathrm{E}+00$ & $1,26 E+01$ \\
\hline paciente 11 & $2,89 E-01$ & $1,63 E+00$ & $3,22 E+00$ & $4,04 E+00$ \\
\hline paciente 17 & $5,64 \mathrm{E}-01$ & $1,75 E+01$ & $1,29 \mathrm{E}-01$ & $5,23 E-01$ \\
\hline \multirow[t]{2}{*}{ paciente 12} & $1,56 \mathrm{E}-02$ & $2,91 \mathrm{E}+00$ & $5,42 E+00$ & $8,22 \mathrm{E}-01$ \\
\hline & $4,24 \mathrm{E}-01$ & $8,00 E+00$ & & $4,10 \mathrm{E}-01$ \\
\hline paciente 10 & 1,31E-01 & & $1,23 E-02$ & $1,14 \mathrm{E}-01$ \\
\hline
\end{tabular}


ANEXO D - Dados da análise morfométrica de tecido muscular liso perilesional de endometriose do reto-sigmoide

\begin{tabular}{|c|c|c|c|c|}
\hline PROLIFERATIVA & HOXA10 & ER- $\boldsymbol{\beta}$ & PR-AB & PR-B \\
\hline \multirow[t]{3}{*}{ paciente 02} & 9,99E-02 & $6,12 \mathrm{E}+00$ & $4,15 \mathrm{E}-01$ & $5,83 \mathrm{E}-01$ \\
\hline & $1,12 \mathrm{E}+00$ & $3,94 \mathrm{E}+00$ & $1,43 \mathrm{E}-01$ & $2,52 \mathrm{E}-01$ \\
\hline & & $1,28 \mathrm{E}+01$ & $5,89 \mathrm{E}-02$ & \\
\hline \multirow[t]{3}{*}{ paciente 05} & 1,82E-01 & $3,57 E+00$ & $1,28 \mathrm{E}+00$ & $6,86 \mathrm{E}-01$ \\
\hline & $8,50 E+00$ & $6,32 \mathrm{E}+00$ & $8,83 E+00$ & $1,54 \mathrm{E}+01$ \\
\hline & & $6,20 E+00$ & & \\
\hline \multirow[t]{9}{*}{ paciente 06} & 3,89E-01 & $9,29 E+00$ & 4,30E-01 & $1,83 \mathrm{E}+00$ \\
\hline & 1,11E-01 & $2,38 \mathrm{E}+01$ & $1,19 \mathrm{E}+00$ & $1,58 \mathrm{E}+00$ \\
\hline & $1,12 \mathrm{E}-01$ & $5,83 E+00$ & $4,05 E-01$ & $9,25 \mathrm{E}-01$ \\
\hline & 4,11E-01 & $1,43 E+01$ & $1,52 E+00$ & $4,70 \mathrm{E}+00$ \\
\hline & $1,26 \mathrm{E}+00$ & $5,93 \mathrm{E}+00$ & $1,05 \mathrm{E}+01$ & $4,03 E+00$ \\
\hline & $4,38 \mathrm{E}-01$ & $1,82 \mathrm{E}+01$ & $2,06 \mathrm{E}+00$ & $3,66 \mathrm{E}+00$ \\
\hline & 1,71E-01 & $2,51 \mathrm{E}+01$ & $1,64 \mathrm{E}+00$ & $2,17 \mathrm{E}+00$ \\
\hline & $1,44 \mathrm{E}-01$ & & $1,52 \mathrm{E}+00$ & $1,98 \mathrm{E}+00$ \\
\hline & 1,13E-01 & & $7,50 \mathrm{E}-02$ & $2,27 \mathrm{E}-01$ \\
\hline \multirow[t]{19}{*}{ paciente 14} & $2,33 E+00$ & $3,98 E+00$ & $2,95 \mathrm{E}-01$ & $6,10 \mathrm{E}-01$ \\
\hline & $1,51 \mathrm{E}+00$ & $4,29 \mathrm{E}+00$ & $5,45 \mathrm{E}-02$ & $5,38 \mathrm{E}-01$ \\
\hline & $8,92 \mathrm{E}+00$ & $1,33 E+01$ & $7,65 E+00$ & $8,20 \mathrm{E}+00$ \\
\hline & $1,60 E+00$ & $5,94 \mathrm{E}+00$ & $4,23 E-01$ & $6,10 \mathrm{E}-01$ \\
\hline & $1,46 E+00$ & $5,39 \mathrm{E}+00$ & $3,04 \mathrm{E}+00$ & $4,57 \mathrm{E}+00$ \\
\hline & $1,37 E+00$ & $3,97 E+00$ & $6,83 \mathrm{E}-01$ & $2,34 \mathrm{E}+00$ \\
\hline & 1,61E-02 & $3,33 E+00$ & $5,44 \mathrm{E}-01$ & $2,62 \mathrm{E}+00$ \\
\hline & $2,95 E+00$ & $3,55 E+00$ & $1,40 E+00$ & $1,18 \mathrm{E}+01$ \\
\hline & $1,73 E+00$ & $1,10 E+01$ & $8,74 \mathrm{E}+00$ & $2,51 E+01$ \\
\hline & $1,09 E+00$ & & $1,07 E+01$ & $1,53 \mathrm{E}+01$ \\
\hline & $1,37 \mathrm{E}+00$ & & $1,42 \mathrm{E}+01$ & $3,03 E+00$ \\
\hline & $3,21 \mathrm{E}-01$ & & $2,34 \mathrm{E}-01$ & $2,49 E+00$ \\
\hline & 5,59E-01 & & $2,75 E+00$ & $1,12 \mathrm{E}+00$ \\
\hline & $1,14 \mathrm{E}+00$ & & $6,16 \mathrm{E}-01$ & $2,86 \mathrm{E}-01$ \\
\hline & 4,64E-01 & & $1,51 E+00$ & $2,28 \mathrm{E}+00$ \\
\hline & $3,78 \mathrm{E}+00$ & & $1,40 E+00$ & $3,44 \mathrm{E}-01$ \\
\hline & $5,84 \mathrm{E}+00$ & & $3,79 \mathrm{E}-01$ & $1,74 \mathrm{E}+00$ \\
\hline & $3,19 E+00$ & & $1,11 E+00$ & $5,36 E+00$ \\
\hline & & & $4,37 \mathrm{E}-02$ & \\
\hline \multirow[t]{8}{*}{ paciente 15} & $2,28 \mathrm{E}-01$ & $1,13 E+00$ & $2,58 \mathrm{E}+00$ & $3,09 \mathrm{E}+00$ \\
\hline & 9,17E-01 & $6,14 E+00$ & $8,49 E+00$ & $3,32 \mathrm{E}-01$ \\
\hline & $1,71 E+00$ & $4,71 E+00$ & $6,77 \mathrm{E}-02$ & $2,11 \mathrm{E}-01$ \\
\hline & $1,86 \mathrm{E}-01$ & $3,35 E+00$ & $1,76 \mathrm{E}-01$ & $4,52 \mathrm{E}-01$ \\
\hline & 4,83E-01 & $7,50 E+00$ & $1,86 \mathrm{E}-01$ & $3,55 \mathrm{E}-01$ \\
\hline & 4,30E-01 & $4,66 \mathrm{E}+00$ & $4,21 E+00$ & $8,43 E+00$ \\
\hline & $2,16 E+00$ & $5,70 E+00$ & & \\
\hline & & $4,07 E+00$ & & \\
\hline \multirow[t]{9}{*}{ paciente 16} & 1,89E-01 & $5,82 \mathrm{E}+00$ & $1,94 \mathrm{E}-01$ & $1,08 \mathrm{E}+00$ \\
\hline & $7,86 \mathrm{E}-02$ & $8,75 E+00$ & $1,42 \mathrm{E}-01$ & $2,04 \mathrm{E}-01$ \\
\hline & $6,63 \mathrm{E}-02$ & $8,07 E+00$ & $1,33 E+01$ & $1,44 E+00$ \\
\hline & $2,21 \mathrm{E}-01$ & & $4,81 \mathrm{E}-01$ & $4,87 E+00$ \\
\hline & 5,37E-01 & & $1,94 \mathrm{E}+00$ & 1,19E-01 \\
\hline & $2,95 \mathrm{E}-02$ & & $9,31 \mathrm{E}-02$ & \\
\hline & & & $1,27 E-01$ & \\
\hline & & & $6,50 E+00$ & \\
\hline & & & $7,65 \mathrm{E}-02$ & \\
\hline \multirow[t]{2}{*}{ paciente 18} & 2,85E-01 & $6,96 \mathrm{E}+00$ & $7,33 \mathrm{E}-02$ & $2,24 \mathrm{E}-01$ \\
\hline & $1,05 \mathrm{E}-01$ & $8,75 E+00$ & $1,37 E+00$ & $1,08 \mathrm{E}+00$ \\
\hline
\end{tabular}




\begin{tabular}{|c|c|c|c|c|}
\hline \multirow{12}{*}{$\begin{array}{l}\text { SECRETORA } \\
\text { paciente } 01\end{array}$} & HOXA10 & ER- $\beta$ & PR-AB & PR-B \\
\hline & $1,05 E+00$ & $2,49 \mathrm{E}+00$ & $5,77 \mathrm{E}+00$ & $5,71 \mathrm{E}+00$ \\
\hline & 3,07E-01 & $5,43 E+00$ & $1,89 \mathrm{E}+00$ & $3,14 E+00$ \\
\hline & $1,22 E+00$ & $3,73 E+00$ & $8,10 E+00$ & $8,56 E+00$ \\
\hline & $3,44 E+00$ & $3,83 \mathrm{E}+00$ & $1,57 \mathrm{E}+01$ & $1,84 \mathrm{E}+01$ \\
\hline & $6,29 \mathrm{E}-01$ & $6,83 E+00$ & $2,20 E+00$ & $2,93 E+00$ \\
\hline & $1,85 \mathrm{E}-01$ & $4,08 \mathrm{E}+00$ & $6,34 \mathrm{E}+00$ & $9,18 \mathrm{E}-02$ \\
\hline & $2,04 E+00$ & $3,46 E+00$ & $9,15 E-03$ & $4,64 E+00$ \\
\hline & $1,07 E+00$ & $1,21 E+00$ & $1,19 \mathrm{E}-01$ & $3,10 \mathrm{E}-01$ \\
\hline & $4,63 E+00$ & & $1,09 \mathrm{E}+00$ & $1,02 \mathrm{E}+00$ \\
\hline & $1,40 E+00$ & & $2,55 \mathrm{E}+00$ & $1,42 \mathrm{E}+00$ \\
\hline & $9,99 \mathrm{E}-03$ & & & $2,81 E+00$ \\
\hline \multirow[t]{19}{*}{ paciente 03} & $3,35 \mathrm{E}-01$ & $4,01 E+00$ & $7,39 \mathrm{E}-01$ & $3,28 \mathrm{E}+00$ \\
\hline & $3,92 \mathrm{E}-01$ & $3,25 \mathrm{E}+00$ & $1,16 \mathrm{E}+01$ & $1,14 E+00$ \\
\hline & $5,42 \mathrm{E}-01$ & $3,83 E+00$ & $5,66 \mathrm{E}+00$ & $1,42 \mathrm{E}+01$ \\
\hline & $8,08 \mathrm{E}-01$ & $1,97 \mathrm{E}+00$ & $4,07 E+00$ & $4,11 E+00$ \\
\hline & $2,58 \mathrm{E}-01$ & $1,88 \mathrm{E}+00$ & $1,10 E+01$ & $1,05 E+01$ \\
\hline & $8,90 \mathrm{E}-02$ & $1,52 \mathrm{E}+01$ & $6,07 \mathrm{E}-01$ & $3,61 \mathrm{E}+00$ \\
\hline & $3,15 \mathrm{E}-01$ & $3,05 \mathrm{E}+01$ & $7,07 \mathrm{E}-01$ & $8,39 \mathrm{E}-01$ \\
\hline & $1,36 \mathrm{E}-01$ & $1,78 \mathrm{E}+01$ & $5,09 \mathrm{E}-01$ & $1,13 E+00$ \\
\hline & $9,09 \mathrm{E}-01$ & $6,01 \mathrm{E}+00$ & $6,75 \mathrm{E}-01$ & $7,22 \mathrm{E}+00$ \\
\hline & $9,94 \mathrm{E}-01$ & $5,61 \mathrm{E}+00$ & $1,90 \mathrm{E}-01$ & $9,03 E-01$ \\
\hline & $4,36 \mathrm{E}-01$ & $1,07 E+01$ & $3,83 E+00$ & $9,41 \mathrm{E}-01$ \\
\hline & $2,72 \mathrm{E}-01$ & $3,15 E+00$ & $4,09 E+00$ & $6,02 E+00$ \\
\hline & $3,68 \mathrm{E}-01$ & $1,24 \mathrm{E}+01$ & $9,15 E+00$ & $6,14 \mathrm{E}+00$ \\
\hline & $1,43 \mathrm{E}-01$ & $1,16 \mathrm{E}+01$ & $3,66 \mathrm{E}+01$ & $4,17 E+00$ \\
\hline & $9,88 \mathrm{E}-02$ & $3,35 \mathrm{E}+00$ & $3,22 E+00$ & $3,78 \mathrm{E}+00$ \\
\hline & $3,15 \mathrm{E}-01$ & & $2,41 \mathrm{E}-01$ & $2,00 E+00$ \\
\hline & $2,83 \mathrm{E}-01$ & & $1,65 E+00$ & $2,74 \mathrm{E}+00$ \\
\hline & $6,24 \mathrm{E}-01$ & & $1,64 \mathrm{E}+00$ & $3,43 E+00$ \\
\hline & $1,98 \mathrm{E}+00$ & & $3,46 E+00$ & $3,42 \mathrm{E}+00$ \\
\hline \multirow[t]{7}{*}{ paciente 04} & $8,86 \mathrm{E}-01$ & $8,23 E+00$ & $8,42 \mathrm{E}-01$ & $9,07 E+00$ \\
\hline & $8,74 \mathrm{E}-01$ & $5,32 \mathrm{E}+01$ & $2,45 \mathrm{E}-01$ & $4,28 \mathrm{E}-01$ \\
\hline & $1,12 \mathrm{E}-01$ & $1,14 \mathrm{E}+00$ & $1,74 \mathrm{E}-01$ & $4,74 E+00$ \\
\hline & $1,85 \mathrm{E}-01$ & $1,05 \mathrm{E}+00$ & $1,27 \mathrm{E}+00$ & $3,11 \mathrm{E}+00$ \\
\hline & $1,59 \mathrm{E}-01$ & $5,58 \mathrm{E}+00$ & $5,13 E+00$ & \\
\hline & & $1,63 E+00$ & $6,48 \mathrm{E}-01$ & \\
\hline & & & $1,35 \mathrm{E}+00$ & \\
\hline \multirow[t]{5}{*}{ paciente 06} & $8,98 \mathrm{E}-02$ & $3,34 \mathrm{E}+00$ & $2,65 \mathrm{E}-01$ & $1,16 E+00$ \\
\hline & 2,64E-01 & $2,46 E+00$ & $5,40 \mathrm{E}-01$ & $2,27 E+00$ \\
\hline & & $2,19 E+00$ & $3,80 \mathrm{E}-01$ & \\
\hline & & $2,03 E+00$ & & \\
\hline & & $6,61 \mathrm{E}+00$ & & \\
\hline paciente 08 & $4,07 E+00$ & $3,79 E+00$ & $6,50 \mathrm{E}-01$ & $1,16 E+00$ \\
\hline paciente 11 & $1,43 E-01$ & $4,78 \mathrm{E}+00$ & $2,62 E-01$ & 4,24E-01 \\
\hline paciente 17 & $2,28 \mathrm{E}+00$ & $5,86 \mathrm{E}+00$ & $1,97 \mathrm{E}+01$ & $3,20 E+01$ \\
\hline \multirow[t]{12}{*}{ paciente 12} & $1,34 \mathrm{E}+00$ & $5,45 \mathrm{E}+00$ & $3,50 E+00$ & $4,88 \mathrm{E}+00$ \\
\hline & $8,90 \mathrm{E}-01$ & $1,34 \mathrm{E}+00$ & $2,39 \mathrm{E}+00$ & $2,98 \mathrm{E}+00$ \\
\hline & $3,74 \mathrm{E}-02$ & $3,09 \mathrm{E}+00$ & 1,67E-01 & $1,50 E+00$ \\
\hline & $3,70 \mathrm{E}-02$ & $5,27 E+00$ & 2,15E-01 & $1,23 E+00$ \\
\hline & $4,58 \mathrm{E}-01$ & $2,63 E+00$ & $3,17 \mathrm{E}-01$ & $1,40 E+00$ \\
\hline & $1,24 \mathrm{E}-01$ & $5,20 \mathrm{E}+00$ & $3,39 \mathrm{E}-01$ & $4,81 E+00$ \\
\hline & $1,90 \mathrm{E}-01$ & $4,25 E+00$ & $7,81 E+00$ & $1,19 E+01$ \\
\hline & $1,17 \mathrm{E}+00$ & $1,30 \mathrm{E}+01$ & $9,08 \mathrm{E}-01$ & $5,08 \mathrm{E}-01$ \\
\hline & $3,56 E+00$ & & $1,01 \mathrm{E}-01$ & 2,90E-01 \\
\hline & & & $1,39 \mathrm{E}-03$ & \\
\hline & & & $2,69 \mathrm{E}-02$ & \\
\hline & & & $1,05 E+01$ & \\
\hline \multirow[t]{2}{*}{ paciente 10} & 1,27E-01 & $1,02 E+01$ & $4,18 \mathrm{E}+00$ & $5,10 E+00$ \\
\hline & $1,69 \mathrm{E}-01$ & $1,15 E+01$ & $1,28 \mathrm{E}+00$ & $1,11 \mathrm{E}+00$ \\
\hline
\end{tabular}


1. Clement PB. The pathology of endometriosis: a survey of the many faces of a common disease emphasizing diagnostic pitfalls and unusual and newly appreciated aspects. Adv Anat Pathol. 2007;14:241-60.

2. Eskenazi B, Warner ML. Epidemiology of endometriosis. Obstet Gynecol Clin North Am. 1997;24:235-58.

3. Fourquet J, Baez L, Figueroa M, Iriarte RI, Flores I. Quantification of the impact of endometriosis symptoms on health-related quality of life and work productivity. Fertil Steril. 2011;96:107-12.

4. Simoens S, Dunselman G, Dirksen C, Hummelshoj L, Bokor A, Brandes I, Brodszky V, Canis M, Colombo GL, DeLeire T, Falcone T, Graham B, Halis G, Horne A, Kanj O, Kjer JJ, Kristensen J, Lebovic D, Mueller M, Vigano P, Wullschleger M, D'Hooghe T. The burden of endometriosis: costs and quality of life of women with endometriosis and treated in referral centres. Hum Reprod. 2012;27:1292-9.

5. Nisolle M, Donnez J. Peritoneal endometriosis, ovarian endometriosis, and adenomyotic nodules of the rectovaginal septum are three different entities. Fertil Steril. 1997;68:585-96.

6. Cornillie FJ, Oosterlynck D, Lauweryns JM, Koninckx PR. Deeply infiltrating pelvic endometriosis: histology and clinical significance. Fertil Steril. 1990; 53:978-83.

7. Donnez J, Squifflet J. Laparoscopic excision of deep endometriosis. Obstet Gynecol Clin North Am. 2004;31:567-80, ix.

8. Koninckx PR. Biases in the endometriosis literature. Illustrated by 20 years of endometriosis research in Leuven. Eur J Obstet Gynecol Reprod Biol. 1998;81:259-71.

9. Bianchi PH, Pereira RM, Zanatta A, Alegretti JR, Motta EL, Serafini PC. Extensive excision of deep infiltrative endometriosis before in vitro fertilization significantly improves pregnancy rates. J Minim Invasive Gynecol. 2009;16:174-80.

10. de Ziegler D, Borghese B, Chapron C. Endometriosis and infertility: pathophysiology and management. Lancet. 2010; 376:730-8.

11. Koninckx PR, Ussia A, Adamyan L, Wattiez A, Donnez J. Deep endometriosis: definition, diagnosis, and treatment. Fertil Steril. 2012;98:564-71. 
12. Fujishita A, Nakane PK, Koji T, Masuzaki H, Chavez RO, Yamabe T, Ishimaru T. Expression of estrogen and progesterone receptors in endometrium and peritoneal endometriosis: an immunohistochemical and in situ hybridization study. Fertil Steril. 1997;67:856-64.

13. Brandenberger AW, Lebovic DI, Tee MK, Ryan IP, Tseng JF, Jaffe $\mathrm{RB}$, Taylor RN. Oestrogen receptor (ER)-alpha and ER-beta isoforms in normal endometrial and endometriosis-derived stromal cells. Mol Hum Reprod. 1999;5:651-5.

14. Attia GR, Zeitoun K, Edwards D, Johns A, Carr BR, Bulun SE. Progesterone receptor isoform $A$ but not $B$ is expressed in endometriosis. J Clin Endocrinol Metab. 2000;85:2897-902.

15. Browne $\mathrm{H}$, Taylor $\mathrm{H}$. HOXA10 expression in ectopic endometrial tissue. Fertil Steril. 2006;85:1386-90.

16. Wu Y, Strawn E, Basir Z, Halverson G, Guo SW. Promoter hypermethylation of progesterone receptor isoform $B$ (PR-B) in endometriosis. Epigenetics. 2006;1:106-11.

17. Xue Q, Lin Z, Cheng YH, Huang CC, Marsh E, Yin P, Milad MP, Confino E, Reierstad S, Innes J, Bulun SE. Promoter methylation regulates estrogen receptor 2 in human endometrium and endometriosis. Biol Reprod. 2007;77:681-7.

18. Meola J, Rosa e Silva JC, Dentillo DB, da Silva WAJ, Veiga-Castelli LC, de Souza Bernardes LA, Ferriani RA, Paro de Paz CC, Giuliatti S, Martelli L. Differentially expressed genes in eutopic and ectopic endometrium of women with endometriosis. Fertil Steril. 2009;93:1750-73.

19. Bazot M, Darai E, Hourani R, Thomassin I, Cortez A, Uzan S, Buy JN. Deep pelvic endometriosis: MR imaging for diagnosis and prediction of extension of disease. Radiology. 2004;232:379-89.

20. Pereira RM, Zanatta A, Preti CD, de Paula FJ, da Motta EL, Serafini PC. Should the gynecologist perform laparoscopic bowel resection to treat endometriosis? Results over 7 years in 168 patients. J Minim Invasive Gynecol. 2009; 16:472-9.

21. Darai E, Marpeau O, Thomassin I, Dubernard G, Barranger E, Bazot M. Fertility after laparoscopic colorectal resection for endometriosis: preliminary results. Fertil Steril. 2005;84:945-50. 
22. Dubernard G, Rouzier R, David-Montefiore E, Bazot M, Darai E. Use of the SF-36 questionnaire to predict quality-of-life improvement after laparoscopic colorectal resection for endometriosis. Hum Reprod. 2008;23:846-51.

23. Stepniewska A, Pomini P, Scioscia M, Mereu L, Ruffo G, Minelli L. Fertility and clinical outcome after bowel resection in infertile women with endometriosis. Reprod Biomed Online. 2010;20:602-9.

24. Ruffo G, Scopelliti F, Scioscia M, Ceccaroni M, Mainardi P, Minelli L. Laparoscopic colorectal resection for deep infiltrating endometriosis: analysis of 436 cases. Surg Endosc. 2009;24:63-7.

25. Pereira RM, Zanatta A, Serafini PC, Redwine D. The feasibility of laparoscopic bowel resection performed by a gynaecologist to treat endometriosis. Curr Opin Obstet Gynecol. 2010;22:344-53.

26. Stepniewska A, Pomini P, Guerriero M, Scioscia M, Ruffo G, Minelli L. Colorectal endometriosis: benefits of long-term follow-up in patients who underwent laparoscopic surgery. Fertil Steril. 2010;93:2444-6.

27. Kitano T, Matsumoto $\mathrm{T}$, Takeuchi H, Kikuchi I, Itoga T, Sasahara N, Kinoshita K. Expression of estrogen and progesterone receptors in smooth muscle metaplasia of rectovaginal endometriosis. Int $J$ Gynecol Pathol. 2007;26:124-9.

28. Noel JC, Chapron C, Bucella D, Buxant F, Peny MO, Fayt I, Borghese $\mathrm{B}$, Anaf $\mathrm{V}$. Estrogen and progesterone receptors in smooth muscle component of deep infiltrating endometriosis. Fertil Steril. 2009;93:1774-7.

29. McGinnis W, Krumlauf R. Homeobox genes and axial patterning. Cell. 1992;68:283-302.

30. McGinnis W, Levine MS, Hafen E, Kuroiwa A, Gehring WJ. A conserved DNA sequence in homoeotic genes of the Drosophila Antennapedia and bithorax complexes. Nature. 1984;308:428-33.

31. Krumlauf R. Hox genes in vertebrate development. Cell. 1994;78:191201.

32. Kappen C, Schughart K, Ruddle FH. Early evolutionary origin of major homeodomain sequence classes. Genomics. 1993;18:54-70. 
33. Morata G, Kornberg T, Lawrence PA. The phenotype of engrailed mutations in the antenna of Drosophila. Dev Biol. 1983;99:27-33.

34. Haney AF, Hammond CB, Soules MR, Creasman WT. Diethylstilbestrol-induced upper genital tract abnormalities. Fertil Steril. 1979; 31:142-6.

35. Block K, Kardana A, Igarashi $\mathrm{P}$, Taylor HS. In utero diethylstilbestrol (DES) exposure alters Hox gene expression in the developing mullerian system. Faseb J. 2000;14:1101-8.

36. Taylor HS, Vanden Heuvel GB, Igarashi P. A conserved Hox axis in the mouse and human female reproductive system: late establishment and persistent adult expression of the Hoxa cluster genes. Biol Reprod. 1997;57:1338-45.

37. Cheng Z, Zhu Y, Su D, Wang J, Cheng L, Chen B, Wei Z, Zhou P, Wang $B$, Ma X, Cao Y. A novel mutation of HOXA10 in a Chinese woman with a Mullerian duct anomaly. Hum Reprod. 2011;26:3197201.

38. Ekici AB, Strissel PL, Oppelt PG, Renner SP, Brucker S, Beckmann MW, Strick R. HOXA10 and HOXA13 sequence variations in human female genital malformations including congenital absence of the uterus and vagina. Gene. 2013;518:267-72.

39. Picchi J, Trombi L, Spugnesi L, Barachini S, Maroni G, Brodano GB, Boriani S, Valtieri M, Petrini M, Magli MC. HOX and TALE signatures specify human stromal stem cell populations from different sources. $J$ Cell Physiol. 2013;228:879-89.

40. Cermik D, Karaca M, Taylor HS. HOXA10 expression is repressed by progesterone in the myometrium: differential tissue-specific regulation of HOX gene expression in the reproductive tract. J Clin Endocrinol Metab. 2001;86:3387-92.

41. Taylor HS, Arici A, Olive D, Igarashi P. HOXA10 is expressed in response to sex steroids at the time of implantation in the human endometrium. J Clin Invest. 1998;101:1379-84.

42. Satokata I, Benson G, Maas R. Sexually dimorphic sterility phenotypes in Hoxa10-deficient mice. Nature. 1995;374:460-3. 
43. Bagot CN, Troy PJ, Taylor HS. Alteration of maternal Hoxa10 expression by in vivo gene transfection affects implantation. Gene Ther. 2000;7:1378-84.

44. Daftary GS, Taylor HS. Implantation in the human: the role of HOX genes. Semin Reprod Med. 2000;18:311-20.

45. Zanatta A, Rocha AM, Carvalho FM, Pereira RM, Taylor HS, Motta EL, Baracat EC, Serafini PC. The role of the Hoxa10/HOXA10 gene in the etiology of endometriosis and its related infertility: a review. J Assist Reprod Genet. 2010;27:701-10.

46. Van Langendonckt A, Luyckx M, Gonzalez MD, Defrere S, Donnez J, Squifflet J. Differential expression of genes from the homeobox $A$ cluster in deep endometriotic nodules and peritoneal lesions. Fertil Steril. 2010;94:1995-2000.

47. Bulun SE, Cheng YH, Pavone ME, Xue Q, Attar E, Trukhacheva E, Tokunaga $\mathrm{H}$, Utsunomiya $\mathrm{H}$, Yin $\mathrm{P}$, Luo X, Lin Z, Imir G, Thung S, Su EJ, Kim JJ. Estrogen receptor-beta, estrogen receptor-alpha, and progesterone resistance in endometriosis. Semin Reprod Med. 2010;28:36-43.

48. Bulun SE, Monsavais D, Pavone ME, Dyson M, Xue Q, Attar E, Tokunaga $\mathrm{H}$, Su EJ. Role of estrogen receptor-beta in endometriosis. Semin Reprod Med. 2012;30:39-45.

49. Pettersson K, Gustafsson JA. Role of estrogen receptor beta in estrogen action. Annu Rev Physiol. 2001;63:165-92.

50. Green S, Walter P, Kumar V, Krust A, Bornert JM, Argos P, Chambon $P$. Human oestrogen receptor cDNA: sequence, expression and homology to v-erb-A. Nature. 1986;320:134-9.

51. Mosselman S, Polman J, Dijkema R. ER beta: identification and characterization of a novel human estrogen receptor. FEBS Lett. 1996;392:49-53.

52. Kuiper GG, Enmark E, Pelto-Huikko M, Nilsson S, Gustafsson JA. Cloning of a novel receptor expressed in rat prostate and ovary. Proc Natl Acad Sci U S A. 1996;93:5925-30.

53. Bhat RA, Harnish DC, Stevis PE, Lyttle CR, Komm BS. A novel human estrogen receptor beta: identification and functional analysis of 
additional N-terminal amino acids. J Steroid Biochem Mol Biol. 1998;67:233-40.

54. Petersen DN, Tkalcevic GT, Koza-Taylor PH, Turi TG, Brown TA. Identification of estrogen receptor beta2, a functional variant of estrogen receptor beta expressed in normal rat tissues. Endocrinology. 1998;139:1082-92.

55. Ogawa S, Inoue S, Watanabe T, Orimo A, Hosoi T, Ouchi Y, Muramatsu M. Molecular cloning and characterization of human estrogen receptor betacx: a potential inhibitor ofestrogen action in human. Nucleic Acids Res. 1998;26:3505-12.

56. Moore JT, McKee DD, Slentz-Kesler K, Moore LB, Jones SA, Horne EL, Su JL, Kliewer SA, Lehmann JM, Willson TM. Cloning and characterization of human estrogen receptor beta isoforms. Biochem Biophys Res Commun. 1998;247:75-8.

57. Watanabe T, Inoue S, Ogawa S, Ishii Y, Hiroi H, Ikeda K, Orimo A, Muramatsu M. Agonistic effect of tamoxifen is dependent on cell type, ERE-promoter context, and estrogen receptor subtype: functional difference between estrogen receptors alpha and beta. Biochem Biophys Res Commun. 1997;236:140-5.

58. Burns KA, Rodriguez KF, Hewitt SC, Janardhan KS, Young SL, Korach KS. Role of estrogen receptor signaling required for endometriosis-like lesion establishment in a mouse model. Endocrinology. 2012;153:3960-71.

59. Kulakosky PC, McCarty MA, Jernigan SC, Risinger KE, Klinge CM. Response element sequence modulates estrogen receptor alpha and beta affinity and activity. J Mol Endocrinol. 2002;29:137-52.

60. Guo SW, Olive DL. Two unsuccessful clinical trials on endometriosis and a few lessons learned. Gynecol Obstet Invest. 2007;64:24-35.

61. Fujimoto J, Hirose $R$, Sakaguchi $H$, Tamaya $T$. Expression of oestrogen receptor-alpha and -beta in ovarian endometriomata. Mol Hum Reprod. 1999;5:742-7.

62. Harris HA, Bruner-Tran $\mathrm{KL}$, Zhang $\mathrm{X}$, Osteen KG, Lyttle CR. A selective estrogen receptor-beta agonist causes lesion regression in an experimentally induced model of endometriosis. Hum Reprod. 2005;20:936-41. 
63. Trukhacheva E, Lin Z, Reierstad S, Cheng YH, Milad M, Bulun SE. Estrogen receptor (ER) beta regulates ERalpha expression in stromal cells derived from ovarian endometriosis. J Clin Endocrinol Metab. 2009;94:615-22.

64. Cavallini A, Resta L, Caringella AM, Dinaro E, Lippolis C, Loverro G. Involvement of estrogen receptor-related receptors in human ovarian endometriosis. Fertil Steril. 2011;96:102-6.

65. Kulak J, Jr., Fischer C, Komm B, Taylor HS. Treatment with bazedoxifene, a selective estrogen receptor modulator, causes regression of endometriosis in a mouse model. Endocrinology. 2011;152:3226-32.

66. Bergqvist A, Ferno M, Skoog L. Quantitative enzyme immunoassay and semiquantitative immunohistochemistry of oestrogen and progesterone receptors in endometriotic tissue and endometrium. $J$ Clin Pathol. 1997;50:496-500.

67. Calcagno A, Grassi T, Mariuzzi L, Marzinotto S, Londero AP, Orsaria M, Beltrami CA, Marchesoni D. Expression patterns of Aurora A and B kinases, Ki-67 and the estrogen and progesterone receptors determined using an endometriosis tissue microarray model. Hum Reprod. 2011;26:2731-41.

68. Samartzis N, Samartzis EP, Noske A, Fedier A, Dedes KJ, Caduff R, Fink D, Imesch P. Expression of the $G$ protein-coupled estrogen receptor (GPER) in endometriosis: a tissue microarray study. Reprod Biol Endocrinol. 2012;10:30.

69. O'Malley BW, Sherman MR, Toft DO. Progesterone "receptors" in the cytoplasm and nucleus of chick oviduct target tissue. Proc Natl Acad Sci U S A. 1970;67:501-8.

70. Lessey BA, Alexander PS, Horwitz KB. The subunit structure of human breast cancer progesterone receptors: characterization by chromatography and photoaffinity labeling. Endocrinology. 1983;112:1267-74.

71. Horwitz KB, Alexander PS. In situ photolinked nuclear progesterone receptors of human breast cancer cells: subunit molecular weights after transformation and translocation. Endocrinology. 1983;113:2195201. 
72. Kastner P, Krust A, Turcotte B, Stropp U, Tora L, Gronemeyer H, Chambon P. Two distinct estrogen-regulated promoters generate transcripts encoding the two functionally different human progesterone receptor forms A and B. Embo J. 1990;9:1603-14.

73. Conneely OM, Maxwell BL, Toft DO, Schrader WT, O'Malley BW. The $A$ and $B$ forms of the chicken progesterone receptor arise by alternate initiation of translation of a unique mRNA. Biochem Biophys Res Commun. 1987;149:493-501.

74. Kastner P, Bocquel MT, Turcotte B, Garnier JM, Horwitz KB, Chambon P, Gronemeyer H. Transient expression of human and chicken progesterone receptors does not support alternative translational initiation from a single mRNA as the mechanism generating two receptor isoforms. J Biol Chem. 1990;265:12163-7.

75. Nardulli AM, Greene GL, O'Malley BW, Katzenellenbogen BS. Regulation of progesterone receptor messenger ribonucleic acid and protein levels in MCF-7 cells by estradiol: analysis of estrogen's effect on progesterone receptor synthesis and degradation. Endocrinology. 1988;122:935-44.

76. Petz LN, Nardulli AM. Sp1 binding sites and an estrogen response element half-site are involved in regulation of the human progesterone receptor A promoter. Mol Endocrinol. 2000;14:972-85.

77. Schultz JR, Petz LN, Nardulli AM. Estrogen receptor alpha and Sp1 regulate progesterone receptor gene expression. Mol Cell Endocrinol. 2003;201:165-75.

78. Vegeto E, Shahbaz MM, Wen DX, Goldman ME, O'Malley BW, McDonnell DP. Human progesterone receptor A form is a cell- and promoter-specific repressor of human progesterone receptor B function. Mol Endocrinol. 1993;7:1244-55.

79. McDonnell DP, Goldman ME. RU486 exerts antiestrogenic activities through a novel progesterone receptor A form-mediated mechanism. $J$ Biol Chem. 1994;269:11945-9.

80. Giangrande $\mathrm{PH}, \mathrm{McD}$ onnell $\mathrm{DP}$. The $\mathrm{A}$ and $\mathrm{B}$ isoforms of the human progesterone receptor: two functionally different transcription factors encoded by a single gene. Recent Prog Horm Res. 1999;54:291-313; discussion -4 . 
81. Shen F, Wang Y, Lu Y, Yuan L, Liu X, Guo SW. Immunoreactivity of progesterone receptor isoform $B$ and nuclear factor kappa-B as biomarkers for recurrence of ovarian endometriomas. Am J Obstet Gynecol. 2008;199:486 e1- e10.

82. Signorile PG, Campioni M, Vincenzi B, D'Avino A, Baldi A. Rectovaginal septum endometriosis: an immunohistochemical analysis of 62 cases. In Vivo. 2009;23:459-64.

83. Daftary GS, Taylor HS. Endocrine regulation of HOX genes. Endocr Rev. 2006;27:331-55.

84. Ma L, Benson GV, Lim H, Dey SK, Maas RL. Abdominal B (AbdB) Hoxa genes: regulation in adult uterus by estrogen and progesterone and repression in mullerian duct by the synthetic estrogen diethylstilbestrol (DES). Dev Biol. 1998;197:141-54.

85. Du H, Daftary GS, Lalwani SI, Taylor HS. Direct regulation of HOXA10 by $1,25-(\mathrm{OH}) 2 \mathrm{D} 3$ in human myelomonocytic cells and human endometrial stromal cells. Mol Endocrinol. 2005;19:2222-33.

86. Cermik D, Selam B, Taylor HS. Regulation of HOXA-10 expression by testosterone in vitro and in the endometrium of patients with polycystic ovary syndrome. J Clin Endocrinol Metab. 2003;88:238-43.

87. Smith CC, Taylor HS. Xenoestrogen exposure imprints expression of genes (Hoxa10) required for normal uterine development. Faseb J. 2007;21:239-46.

88. Akbas GE, Song J, Taylor HS. A HOXA10 estrogen response element (ERE) is differentially regulated by 17 beta-estradiol and diethylstilbestrol (DES). J Mol Biol. 2004;340:1013-23.

89. Wu D, Song D, Li X, Yu M, Li C, Zhao S. Molecular characterization and identification of the E2/P4 response element in the porcine HOXA10 gene. Mol Cell Biochem. 2013;374:213-22.

90. Godbole GB, Modi DN, Puri CP. Regulation of homeobox A10 expression in the primate endometrium by progesterone and embryonic stimuli. Reproduction. 2007;134:513-23.

91. Couse JF, Dixon D, Yates M, Moore AB, Ma L, Maas R, Korach KS. Estrogen receptor-alpha knockout mice exhibit resistance to the developmental effects of neonatal diethylstilbestrol exposure on the female reproductive tract. Dev Biol. 2001;238:224-38. 
92. Marsh EE, Laufer MR. Endometriosis in premenarcheal girls who do not have an associated obstructive anomaly. Fertil Steril. 2005;83:75860.

93. Mok-Lin EY, Wolfberg A, Hollinquist $H$, Laufer MR. Endometriosis in a patient with Mayer-Rokitansky-Kuster-Hauser syndrome and complete uterine agenesis: evidence to support the theory of coelomic metaplasia. J Pediatr Adolesc Gynecol. 2010;23:e35-7.

94. Signorile PG, Baldi F, Bussani R, D'Armiento M, De FM, Baldi A. Ectopic endometrium in human foetuses is a common event and sustains the theory of mullerianosis in the pathogenesis of endometriosis, a disease that predisposes to cancer. J Exp Clin Cancer Res. 2009;28:49.

95. Signorile PG, Baldi F, Bussani R, Viceconte R, Bulzomi P, D'Armiento M, D'Avino A, Baldi A. Embryologic origin of endometriosis: analysis of 101 human female fetuses. J Cell Physiol. 2012;227:1653-6.

96. Bouquet de Joliniere J, Ayoubi JM, Lesec G, Validire P, Goguin A, Gianaroli L, Dubuisson JB, Feki A, Gogusev J. Identification of displaced endometrial glands and embryonic duct remnants in female fetal reproductive tract: possible pathogenetic role in endometriotic and pelvic neoplastic processes. Front Physiol. 2012;3:444.

97. Signorile $P G$, Spugnini EP, Mita L, Mellone $P$, D'Avino A, Bianco M, Diano N, Caputo L, Rea F, Viceconte R, Portaccio M, Viggiano E, Citro G, Pierantoni R, Sica V, Vincenzi B, Mita DG, Baldi F, Baldi A. Pre-natal exposure of mice to bisphenol A elicits an endometriosis-like phenotype in female offspring. Gen Comp Endocrinol. 2010;168:31825.

98. Revised American Fertility Society classification of endometriosis: 1985. Fertil Steril. 1985;43:351-2.

99. Noyes RW, Hertig AT, Rock J. Dating the endometrial biopsy. Fertil Steril. 1950;1:3-25.

100. Kononen J, Bubendorf L, Kallioniemi A, Barlund M, Schraml P, Leighton S, Torhorst J, Mihatsch MJ, Sauter G, Kallioniemi OP. Tissue microarrays for high-throughput molecular profiling of tumor specimens. Nat Med. 1998;4:844-7. 
101. Kallioniemi OP, Wagner U, Kononen J, Sauter G. Tissue microarray technology for high-throughput molecular profiling of cancer. Hum Mol Genet. 2001;10:657-62.

102. Lorente Garin JA, Lloreta Trull J, Allepuz Losa C, Plaza Mas L, Rioja Sanz LA, Gelabert Mas A. Development of tissue microarray technology (TMA) for immunohistochemical study of molecular expression profiling in prostate cancer (part 1). Actas Urol Esp. 2006;30:25-32.

103. Allred DC, Harvey JM, Berardo M, Clark GM. Prognostic and predictive factors in breast cancer by immunohistochemical analysis. Mod Pathol. 1998;11:155-68.

104. McCullagh P, Nelder JA. Generalized linear models. 2nd ed. London: Chapman and Hall; 1989.

105. Anaf V, Simon P, Fayt I, Noel J. Smooth muscles are frequent components of endometriotic lesions. Hum Reprod. 2000;15:767-71.

106. Kamat AA, Younes PS, Sayeeduddin M, Wheeler TM, Simpson JL, Agoulnik Al. Protein expression profiling of endometriosis: validation of 2-mm tissue microarrays. Fertil Steril. 2004;82:1681-3.

107. Krecsak L, Micsik T, Kiszler G, Krenacs T, Szabo D, Jonas V, Csaszar G, Czuni L, Gurzo P, Ficsor L, Molnar B. Technical note on the validation of a semi-automated image analysis software application for estrogen and progesterone receptor detection in breast cancer. Diagn Pathol. 2011;6:6.

108. Yu YY, Pan YS, Zhu ZG. Homeobox genes and their functions on development and neoplasm in gastrointestinal tract. Eur $J$ Surg Oncol. 2007;33:129-32.

109. Minutolo F, Macchia M, Katzenellenbogen BS, Katzenellenbogen JA. Estrogen receptor beta ligands: recent advances and biomedical applications. Med Res Rev. 2011;31:364-442.

110. Bertini S, De Cupertinis A, Granchi C, Bargagli B, Tuccinardi T, Martinelli A, Macchia M, Gunther JR, Carlson KE, Katzenellenbogen JA, Minutolo F. Selective and potent agonists for estrogen receptor beta derived from molecular refinements of salicylaldoximes. Eur $J$ Med Chem. 2011;46:2453-62. 
111. Lessey BA, Metzger DA, Haney AF, McCarty KS, Jr. Immunohistochemical analysis of estrogen and progesterone receptors in endometriosis: comparison with normal endometrium during the menstrual cycle and the effect of medical therapy. Fertil Steril. 1989;51:409-15.

112. Wu Y, Kajdacsy-Balla A, Strawn E, Basir Z, Halverson G, Jailwala P, Wang Y, Wang X, Ghosh S, Guo SW. Transcriptional characterizations of differences between eutopic and ectopic endometrium. Endocrinology. 2006;147:232-46.

113. Bulun SE. Endometriosis. N Engl J Med. 2009;360:268-79.

114. Chehna-Patel N, Sachdeva G, Gajbhiye R, Warty N, Khole V. "Spot"ting differences between the ectopic and eutopic endometrium of endometriosis patients. Fertil Steril. 2010;94:1964-71,71e1.

115. Sharpe-Timms KL. Endometrial anomalies in women with endometriosis. Ann N Y Acad Sci. 2001;943:131-47.

116. Moutsatsou $P$, Sekeris CE. Steroid receptors in the uterus: implications in endometriosis. Ann N Y Acad Sci. 2003;997:209-22.

117. Burney RO, Talbi S, Hamilton AE, Vo KC, Nyegaard M, Nezhat CR, Lessey BA, Giudice LC. Gene expression analysis of endometrium reveals progesterone resistance and candidate susceptibility genes in women with endometriosis. Endocrinology. 2007;148:3814-26.

118. Burney RO, Hamilton AE, Aghajanova L, Vo KC, Nezhat CN, Lessey BA, Giudice LC. MicroRNA expression profiling of eutopic secretory endometrium in women with versus without endometriosis. Mol Human Reprod. 2009;15:625-31.

119. Evers JL. Endometriosis does not exist; all women have endometriosis. Hum Reprod. 1994;9:2206-9.

120. Evers JL, Dunselman GA, Groothuis $P$. Now you see them, now you don't. Fertil Steril. 2005;84:31-2.

121. Hughesdon PE. The endometrial identity of benign stromatosis of the ovary and its relation to other forms of endometriosis. $J$ Pathol. 1976;119:201-9.

122. Redwine DB. Ovarian endometriosis: a marker for more extensive pelvic and intestinal disease. Fertil Steril. 1999;72:310-5. 
123. Chapron C, Pietin-Vialle C, Borghese B, Davy C, Foulot H, Chopin N. Associated ovarian endometrioma is a marker for greater severity of deeply infiltrating endometriosis. Fertil Steril. 2009;92:453-7.

124. Sampson JA. Peritoneal endometriosis due to rhe menstrual dissemination of endometrial tissue into the peritoneal cavity. Am J Obstet Gynecol. 1927;14:422-69.

125. Koninckx PR, Martin DC. Deep endometriosis: a consequence of infiltration or retraction or possibly adenomyosis externa? Fertil Steril. 1992;58:924-8.

126. Somigliana $E$, Infantino $M$, Candiani $M$, Vignali $M$, Chiodini $A$, Busacca M. Association rate between deep peritoneal endometriosis and other forms of the disease: pathogenetic implications. Hum Reprod. 2004;19:168-71.

127. Chapron C, Chopin N, Borghese B, Foulot H, Dousset B, VacherLavenu MC, Vieira M, Hasan W, Bricou A. Deeply infiltrating endometriosis: pathogenetic implications of the anatomical distribution. Hum Reprod. 2006;21:1839-45.

128. Cullen TS. Adenomyoma of the uterus. Philadelphia: W. B. Saunders; 1908.

129. Donnez J, Nisolle M, Smoes P, Gillet N, Beguin S, Casanas-Roux F. Peritoneal endometriosis and "endometriotic" nodules of the rectovaginal septum are two different entities. Fertil Steril. 1996;66:362-8.

130. Redwine DB. Was Sampson wrong? Fertil Steril. 2002;78:686-93.

131. Kim JJ, Taylor HS, Lu Z, Ladhani O, Hastings JM, Jackson KS, Wu Y, Guo SW, Fazleabas AT. Altered expression of HOXA10 in endometriosis: potential role in decidualization. Mol Hum Reprod. 2007;13:323-32.

132. Lee B, Du H, Taylor HS. Experimental murine endometriosis induces DNA methylation and altered gene expression in eutopic endometrium. Biol Reprod. 2009;80:79-85.

133. Afshar Y, Hastings J, Roqueiro D, Jeong JW, Giudice LC, Fazleabas AT. Changes in Eutopic Endometrial Gene Expression During the Progression of Experimental Endometriosis in the Baboon, Papio Anubis. Biol Reprod. 2013;88:1-9. 
134. Russel W. Aberrant portions of the Müllerian duct found in an ovary. John Hopkins Hosp Bull. 1899;10:8-10.

135. Cullen TS. The distribution of adenomyomata containing uterine mucosa. Arch Surg. 1920;1920:215-83.

136. Lamarck JBPAdMd, Gould AA. Lamarck's genera of shells: with a catalogue of species. Boston: Allen and Ticknor; 1833.

137. Darwin C. On the origin of species by means of natural selection. London: J. Murray; 1859.

138. Mendel G. Versuche über Pfanzen-Hybriden. v.4. Brünn: Abhändlungern; 1866.

139. Huxley J. Evolution, the modern synthesis. London: G. Allen \& Unwin; 1942.

140. Watson JD, Crick FH. Molecular structure of nucleic acids; a structure for deoxyribose nucleic acid. Nature. 1953;171:737-8.

141. Finishing the euchromatic sequence of the human genome. Nature. 2004;431:931-45. 
APÊNDICE 


\section{Apêndice A - Parecer ético}

\section{APROVAÇÃO}

A Comissão de Ética para Análise de Projetos de Pesquisa CAPPesq da Diretoria Clínica do Hospital das Clínicas e da Faculdade de Medicina da Universidade de São Paulo, em sessão de 08/09/2010, APROVOU o Protocolo de Pesquisa $n^{\circ}$ 1133/09, intitulado: "EXPRESSÃO DO GENE HOXA10 E DOS RECEPTORES DE PROGESTAGÊNIO E ESTROGÊNIO NO EPITÉLIO E NO ESTROMA DE LESĀO ENDOMETRIÓTICA INTESTINAL E NO TECIDO MUSCULAR LISO PERILESIONAL INFILTRADO DE MULHERES INFÉRTEIS" apresentado pelo Departamento de OBStetrícIA E GINECOLOGIA, inclusive o Termo de Consentimento Livre e Esclarecido.

Cabe ao pesquisador elaborar e apresentar à CAPPesq, os relatórios parciais e final sobre a pesquisa (Resolução do Conselho Nacional de Saúde n*196, de 10/10/1996, inciso IX.2, letra "c").

Pesquisador (a) Responsável: Paulo César Serafini

Pesquisador (a) Executante: Alysson Zanatta

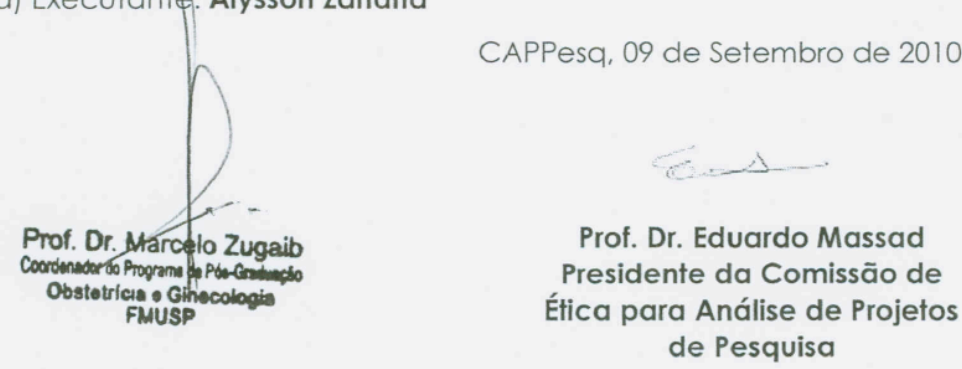




\title{
hOSPITAL dAS CLÍNICAS dA FACULdADE DE MEDICINA dA UNIVERSIDAdE dE SÃO PAULO- HCFMUSP
}

TERMO DE CONSENTIMENTO LIVRE E ESCLARECIDO

\section{DADOS DE IDENTIFICAÇÃO DO SUJEITO DA PESQUISA OU RESPONSÁVEL LEGAL}

\author{
1. NOME: \\ DOCUMENTO DE IDENTIDADE $\mathrm{N}^{\circ}$ : \\ SEXO : .M $\square \quad F$ \\ DATA NASCIMENTO: \\ ENDEREÇO \\ $\mathrm{N}^{\circ}$ \\ APTO: \\ BAIRRO: \\ CIDADE \\ CEP: \\ TELEFONE: DDD \\ ..) \\ 2.RESPONSÁVEL LEGAL \\ NATUREZA (grau de parentesco, tutor, curador etc.) \\ DOCUMENTO DE IDENTIDADE : \\ SEXO: $M \square \quad F \square$ \\ DATA NASCIMENTO.: .................... \\ ENDEREÇO: \\ BAIRRO: \\ $\mathrm{N}^{\circ}$ \\ CEP: \\ CIDADE: \\ TELEFONE: DDD (.............). \\ APTO:
}

\section{DADOS SOBRE A PESQUISA}

1. TítULO dO PROTOCOLO DE PESQUISA: Expressão do gene HOXA10 e dos receptores de progesterona e estrogênio no epitélio e no estroma de lesão endometriótica intestinal e no tecido muscular liso perilesional infiltrado de mulheres inférteis

PESQUISAdOR: Paulo Cesar Serafini

CARGO/FUNÇÃO: Médico colaborador e coordenador do Centro de Reprodução Humana Governador Mário Covas do Departamento de Obstetrícia e Ginecologia da Faculdade de Medicina da Universidade de São Paulo 
INSCRIÇÃO CONSELHO REGIONAL Nº 83425/SP

UNIDADE DO HCFMUSP: Departamento de Obstetrícia e Ginecologia da Faculdade de Medicina da Universidade de São Paulo.

3. AVALIAÇÃO DO RISCO DA PESQUISA:

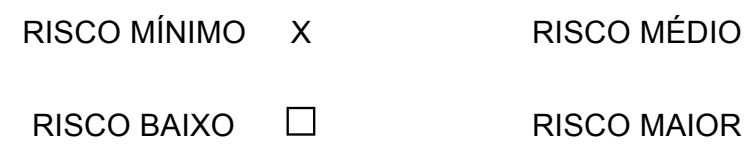

Essas informações estão sendo fornecidas para sua participação voluntária neste estudo, o qual o objetivo principal visa avaliar a presença do gene HOXA10 e de receptores hormonais nas lesões de endometriose intestinal.

O estudo será feito com pacientes que foram submetidas à cirurgia para ressecção de endometriose, incluindo a retirada de endometriose intestinal. Serão analisadas as lâminas das biópsias realizadas destas lesões de endometriose intestinal, especificamente para a pesquisa dos referidos gene e receptores hormonais. Não haverá nenhum desconforto ou procedimento adicional para a senhora durante a realização da pesquisa descrita. Não há benefício direto para sua participação neste estudo. Somente no final do estudo poderemos concluir a presença de algum benefício.

A realização de biópsia de parte ou totalidade de órgãos removidos durante cirurgias é procedimento habitual, e os resultados destas biópsias já lhe foram informados durante seu retorno pós-operatório. O que se fará agora é uma nova análise destas biópsias já realizadas. Para isto, a senhora fará a solicitação de suas lâminas de biópsias ao Setor de Anatomia Patológica do referido hospital onde ocorreu sua cirurgia, e, posteriormente, a senhora cederá estas lâminas das biópsias ao pesquisador responsável, sem custo ou benefício adicional.

Todos os procedimentos a serem realizados são utilizados de rotina na prática clínica.

A senhora terá acesso, a qualquer tempo, às informações sobre procedimentos, riscos e benefícios relacionados à pesquisa, inclusive para esclarecer eventuais dúvidas. 
O principal investigador é o Doutor Paulo Cesar Serafini que pode ser encontrado no Instituto Central do Hospital das Clínicas - FMUSP - Avenida Doutor Enéas de Carvalho Aguiar, 255; CEP: 05403-900 São Paulo - SP - Brasil

Telefone: (11) 30696647

Se a senhora tiver alguma consideração ou dúvida sobre a ética da pesquisa, entre em contato com o Comitê de Ética em Pesquisa (CEP) - Rua Ovídio Pires de Campos, $225-5^{\circ}$ andar

Telefone: (11) 3069-6442 ramais 16, 17, 18 ou 20, FAX: 3069-6442 ramal 26 - E-mail:cappesq@hcnet.usp.br

A senhora terá tem liberdade de retirar seu consentimento a qualquer momento e de deixar de participar do estudo, sem que isto traga prejuízo à continuidade do seu tratamento nesta instituição.

Durante todo o estudo a sua confidencialidade, sigilo e privacidade serão garantidos. As informações obtidas serão analisadas em conjunto com outros pacientes, não sendo divulgada a identificação de nenhum paciente. Os dados obtidos por este estudo serão utilizados somente para pesquisa.

A senhora terá o direito de ser mantida atualizada sobre os resultados parciais da pesquisa e de resultados que sejam do conhecimento dos pesquisadores.

Não haverá despesas pessoais para a senhora em qualquer fase do estudo, incluindo exames e consultas. Também não há compensação financeira relacionada à sua participação. Se existir qualquer despesa adicional, ela será absorvida pelo orçamento da pesquisa. A senhora terá toda assistência no Hospital das Clínicas (HCFMUSP) durante a pesquisa.

Em caso de dano pessoal, diretamente causado pelos procedimentos ou tratamentos propostos neste estudo (nexo causal comprovado), o participante tem direito a tratamento médico na Instituição.

$\mathrm{Eu}$, Paulo Cesar Serafini, pesquisador responsável comprometo-me a utilizar os dados coletados somente para a pesquisa.

Acredito ter sido suficientemente informado a respeito das informações que li ou que foram lidas para mim, descrevendo o estudo: "Expressão do gene HOXA10 e 
dos receptores de progestagênio e estrogênio no epitélio e no estroma de lesão endometriótica intestinal e no tecido muscular liso perilesional infiltrado de mulheres inférteis". Eu discuti com o Doutor Paulo Cesar Serafini sobre a minha decisão em participar nesse estudo. Ficaram claros para mim quais são os propósitos do estudo, os procedimentos a serem realizados, seus desconfortos e riscos, as garantias de confidencialidade e de esclarecimentos permanentes. Ficou claro também que minha participação é isenta de despesas e que tenho garantia do acesso a tratamento hospitalar quando necessário. Concordo voluntariamente em participar deste estudo e poderei retirar o meu consentimento a qualquer momento, antes ou durante o mesmo, sem penalidades ou prejuízo ou perda de qualquer benefício que eu possa ter adquirido, ou no meu atendimento neste Serviço.

Assinatura

paciente/representante legal do

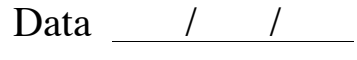

Assinatura da testemunha

Data 11

(Para casos de pacientes menores de 18 anos, analfabetos, semi-analfabetos ou portadores de deficiência auditiva ou visual.)

(Somente para o responsável do projeto)

Declaro que obtive de forma apropriada e voluntária o Consentimento Livre e Esclarecido deste paciente ou representante legal para a participação neste estudo. 